\title{
Good Practices \\ for Financial Consumer \\ Protection
}

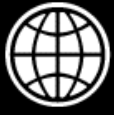

The World Bank

Financial Inclusion Practice

Financial and Private Sector Network

June 2012 
The findings, interpretations, and conclusions expressed in this paper are entirely those of the authors. They do not necessarily represent the views of the International Bank for Reconstruction and Development/World Bank and its affiliated organizations, or those of the Executive Directors of the World Bank or the governments they represent. 


\section{Acknowledgements}

Good Practices for Financial Consumer Protection was prepared by a team led by Susan L. Rutledge, Senior Private Sector Development Specialist at the World Bank. The core team consisted of Nagavalli Annamalai (Lead Counsel), Rodney Lester (Senior Advisor, Retired), and Richard L. Symonds (Senior Counsel, Retired), all from the World Bank. They were joined by Eric Haythorne (Lead Counsel, Retired) and Juan Carlos Izaguirre Araujo (Consultant) also from the World Bank. Also joining the team was Nicola Jentzsch, then Senior Research Fellow, Technische Universität Berlin. In addition, valuable contributions were made by Milton Cartwright, Manager Pensions and Investment Policy of United Kingdom's Financial Services Authority and David Stallibrass of the Office of Fair Trading of the United Kingdom. Special thanks also go to Shaun Mundy, international consultant on financial literacy and former Head of Financial Capability Department of the United Kingdom's Financial Services Authority, Rosamund Grady, Conjoint Professor and Chief Executive Officer at the Sydney-based Centre for International Finance and Regulation, John Pyne, Associate Director of Insurance Supervision at the Qatar Financial Centre Regulatory Authority, and Patrick McAllister, Director of Housing Finance in Asia/Pacific at Habitat for Humanity International. Editorial support was kindly provided by Marga O. De Loayza and Snigdha Verma.

Valuable comments were received from Zoran Anusic, Giuliana Cane, Deepa Chakrapani, Martin Cihak, Massimo Cirasino, Charles Michael Grist, Orsalia Kalantzopoulos, Claire McGuire, Nataliya Mylenko, Antony Randle, Consolate Rusagara and Vijay Srinivas Tata (all World Bank), as well as Denise Dias, Tilman Ehrbeck, Katharine McKee, Timothy Lyman and Rafael Mazer (all from the Consultative Group to Assist the Poor). Thanks also to Marie-Renee Bakker, Marsha Olive, Fernando Montes-Negret and Sophie Sirtaine (all from the World Bank's Europe and Central Asia Region) who supported the early development of the work financial consumer protection.

External peer review comments were gratefully received from Tomás Prouza, Chairman of the Board of the Association of Financial Advisers of the Czech Republic and former Deputy Finance Minister of the Czech Republic, William Knight, Chairman of the International Financial Consumer Protection Network (FinCoNet) and Former Commissioner of the Financial Consumer Agency of Canada. For comments on an early draft, thanks to Sarah Lynch of the European Commission, Jane Rooney, Director of Financial Literacy and Consumer Education at the Financial Consumer Agency of Canada, and Lewis Mandell, Professor and Dean Emeritus, University at Buffalo - The State University of New York and Senior Fellow at the Aspen Institute's Initiative on Financial Security.

Comments were also gratefully received from ACCION International, Alliance for Financial Inclusion, Analistas Financieros Internacionales S.A., Banco de México, Banco de Portugal, Bank of Uganda, Superintendencia de Bancos of Guatemala, Consumers International, International Association of Pension Supervisors, International Network of Financial Ombudsmen, Organisation for Economic Co-operation and Development, Palestine Monetary Authority, Pension Fund Regulatory and Development Authority of India, Polish Financial Supervision Authority, Retirement Commission of the Government of New Zealand, Superintendencia de Banca, Seguros y Administradoras Privadas de Fondos de Pensiones of Peru, Superintendencia de Bancos of Paraguay, Swiss Financial Market Supervisory Authority, TD Bank, UK Financial Ombudsman Service, US Federal Deposit Insurance Corporation, US Federal 
Reserve Board, (US) National Association of Insurance Commissioners, and World Savings Banks Institute. Thank you all for your valuable insights and suggestions.

In addition to World Bank funding, financial support for the work of country diagnostics and implementation programs has been generously provided by the (World) Bank Netherlands Partnership Program (BNPP), the Japan Population and Human Resources Development Program (PHRD), the Financial Sector Reform and Strengthening (FIRST) Initiative, the Swiss State Secretariat for Economic Affairs (SECO), the United Kingdom Department for International Development (DFID) and the United States Agency for International Development (USAID).

\section{Acronyms \& Abbreviations}

$\begin{array}{ll}\text { AML } & \text { Anti-money laundering } \\ \text { ANEC } & \text { European Association for the Co-ordination of Consumer Representation in } \\ & \text { Standardization } \\ \text { APEC } & \text { Asia Pacific Economic Cooperation } \\ \text { API } & \text { Arab Payments Initiative } \\ \text { APY } & \text { Annual percentage yield } \\ \text { ASBA } & \text { Asociación de Supervisores Bancarios de las Américas (Association of } \\ & \text { Supervisors of Banks of the Americas) } \\ \text { B2C } & \text { Business to Consumer } \\ \text { BEUC } & \text { Bureau Européen des Unions des Consommateurs (European Consumers' } \\ & \text { Organisation) } \\ \text { BIS } & \text { Bank for International Settlements } \\ \text { BNPP } & \text { (World) Bank Netherlands Partnership Program } \\ \text { CEMLA } & \text { Centro de Estudios Monetarios Latinoamericanos } \\ \text { CESR } & \text { Committee of European Securities Regulators } \\ \text { CFT } & \text { Combating the financing of terrorism } \\ \text { CGAP } & \text { Consultative Group to Assist the Poor } \\ \text { CISPI } & \text { Commonwealth of Independent States Initiative } \\ \text { CIU } & \text { Collective Investment Undertaking } \\ \text { COE } & \text { Council of Europe } \\ \text { CPSS } & \text { Committee on Payment and Settlement Systems } \\ \text { DFID } & \text { United Kingdom Department for International Development } \\ \text { EC } & \text { European Commission } \\ \text { ECJ } & \text { European Court of Justice } \\ \text { ERISA } & \text { US Employee Retirement Income Security Act } \\ \text { ESIS } & \text { European Standardized Information Sheet } \\ \text { ETS } & \text { European Treaty Series } \\ \text { FIMM } & \text { Federation of Investment Managers Malaysia } \\ \text { EU } & \text { European Union } \\ \text { FATF } & \text { Financial Action Task Force } \\ \text { FCAC } & \text { Financial Consumer Agency of Canada } \\ \text { FDIC } & \text { US Federal Deposit Insurance Corporation } \\ \text { FinCoNet } & \text { International Financial Consumer Protection Network } \\ \text { FINRA } & \text { US Financial Industry Regulatory Authority } \\ \text { FIRST } & \text { Financial Sector Reform and Strengthening Initiative } \\ \text { FSA } & \text { FK Financial Services Authority } \\ \text { FSAP } & \\ & \end{array}$




\begin{tabular}{|c|c|}
\hline FSB & Financial Stability Board \\
\hline FTC & US Federal Trade Commission \\
\hline $\mathrm{G} 20$ & Group of Twenty \\
\hline GDP & Gross domestic product \\
\hline IADB & Inter-American Development Bank \\
\hline IAIS & International Association of Insurance Supervisors \\
\hline $\mathrm{ICO}$ & UK Information Commissioner's Office \\
\hline ICP & Insurance Core Principle \\
\hline IDD & Initial disclosure document \\
\hline IEFP & Institut pour l'Education Financière du Public \\
\hline IFC & International Finance Corporation \\
\hline IFRS & International Financial Reporting Standards \\
\hline IOPS & International Organisation of Pensions Supervisors \\
\hline IOSCO & International Organization of Securities Commissions \\
\hline ISO & International Organization for Standardization \\
\hline KYC & Know Your Customer \\
\hline LIBOR & London Inter-bank Offered Rate \\
\hline MAS & Monetary Authority of Singapore \\
\hline MiFID & Markets in Financial Instruments Directive \\
\hline MSME & Micro, Small and Medium Enterprises \\
\hline NAIC & US National Association of Insurance Commissioners \\
\hline NASD & US National Association of Securities Dealers \\
\hline NGO & Non-government organization \\
\hline NPS & National Payments System \\
\hline OECD & Organisation for Economic Co-operation and Development \\
\hline OTC & Over-the-Counter \\
\hline PIN & Personal identification number \\
\hline PHRD & Japan Population and Human Resources Development Program \\
\hline SADC & Southern African Development Community \\
\hline SAPI & South Asia Payments Initiative \\
\hline SEC & US Securities and Exchange Commission \\
\hline SECCI & Standard European Consumer Credit Information \\
\hline SECO & Swiss State Secretariat for Economic Affairs \\
\hline SEEP & Small Enterprise Education and Promotion Network \\
\hline SEPA & Single Euro Payments Area \\
\hline SFC & Securities and Futures Commission of Hong Kong \\
\hline SME & Small and medium enterprises \\
\hline SRO & Self-regulatory organization \\
\hline TILA & US Truth in Lending Act \\
\hline UCITS & Undertakings for Collective Investment in Transferable Securit \\
\hline UK & United Kingdom \\
\hline UN & United Nations \\
\hline US & United States of America \\
\hline USAID & United States Agency for International Development \\
\hline USC & United States Code \\
\hline WBG & World Bank Group \\
\hline WHCRI & Western Hemisphere Credit and Loan Reporting Initiative \\
\hline
\end{tabular}




\section{Table of Contents}

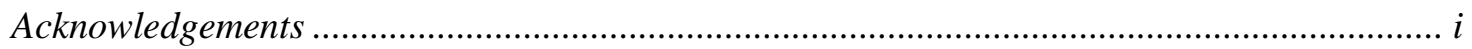

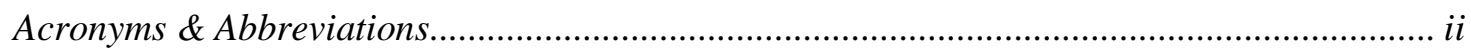

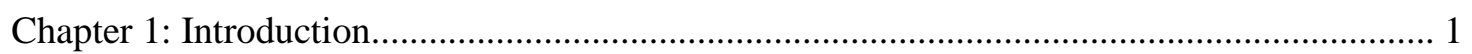

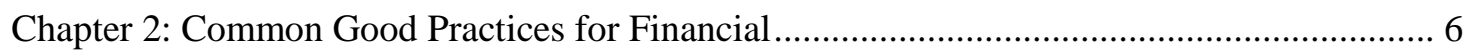

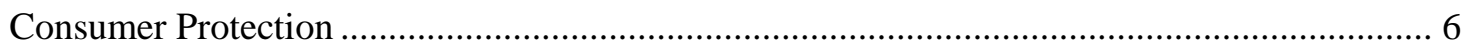

Chapter 3: Good Practices for Financial Consumer Protection by Financial Service .............. 10

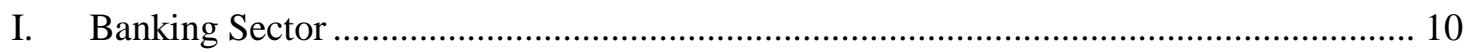

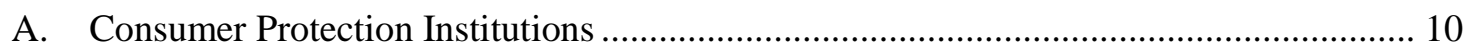

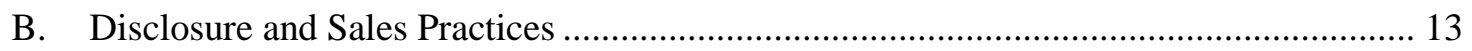

C. Customer Account Handling and Maintenance ........................................................... 19

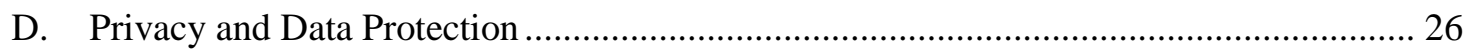

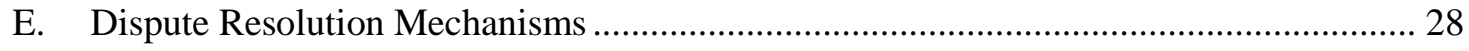

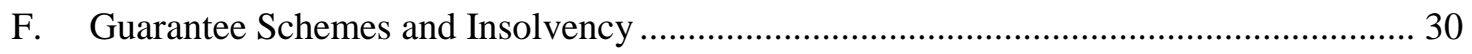

G. Consumer Empowerment \& Financial Literacy ....................................................... 31

H. Competition and Consumer Protection ....................................................................... 34

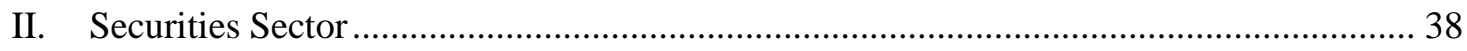

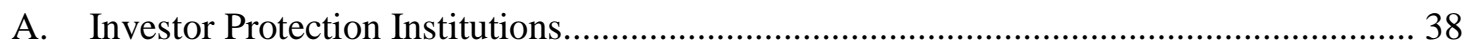

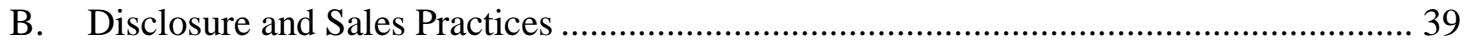

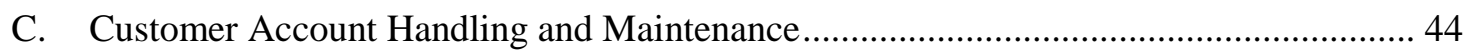

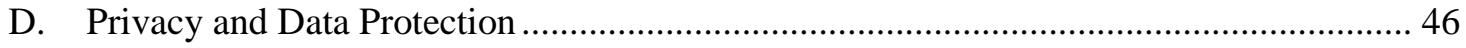

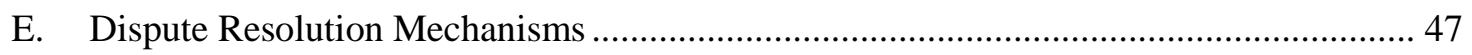

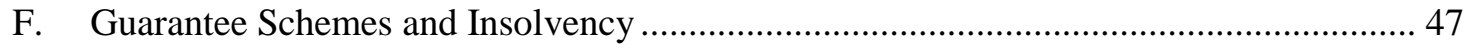

G. Consumer Empowerment \& Financial Literacy ........................................................... 48

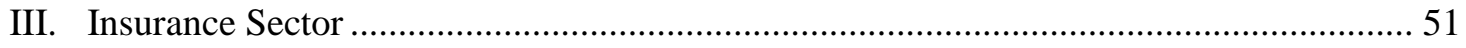

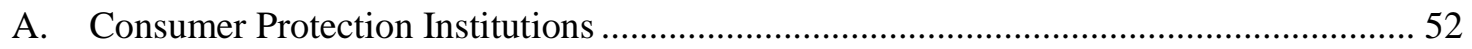

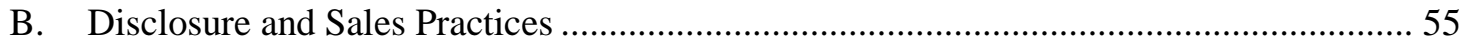

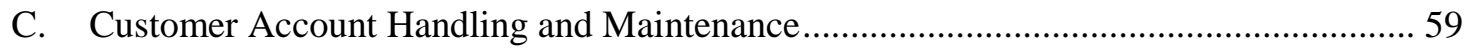

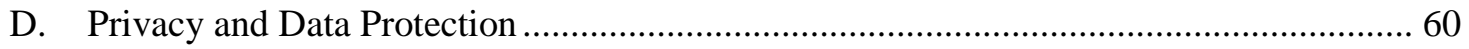

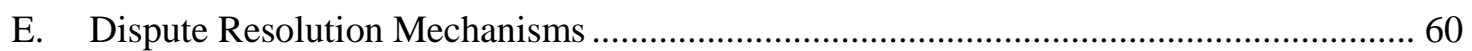

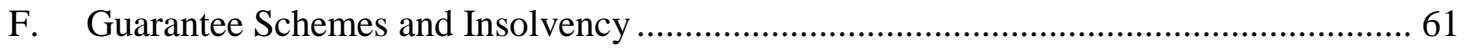

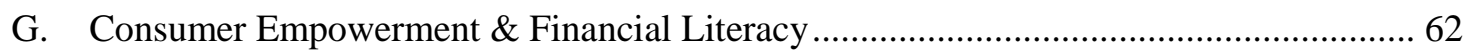

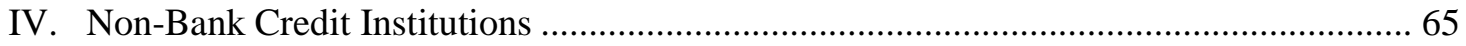

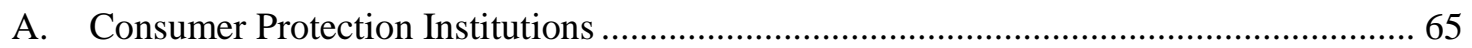

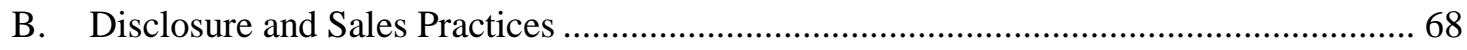

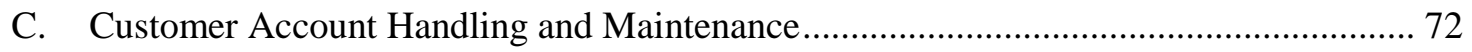

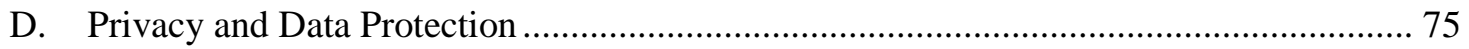

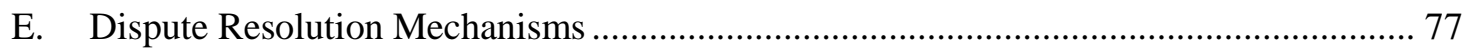

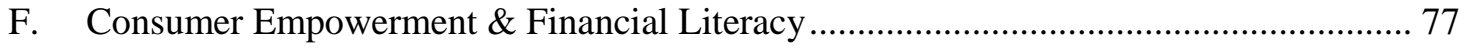




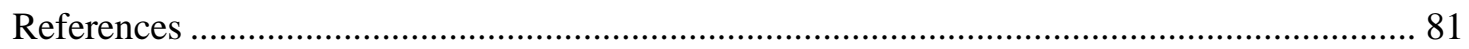

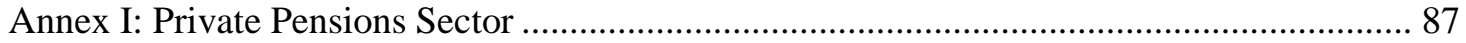

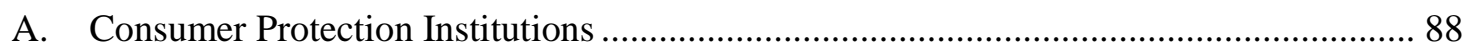

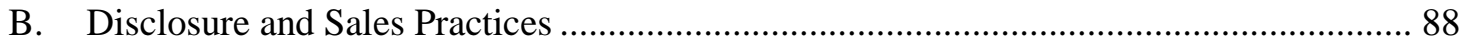

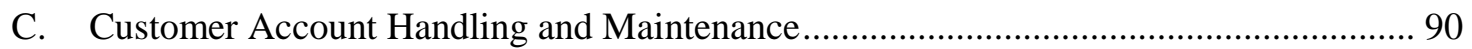

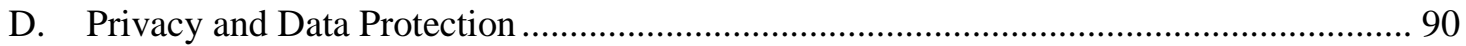

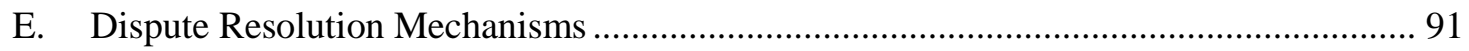

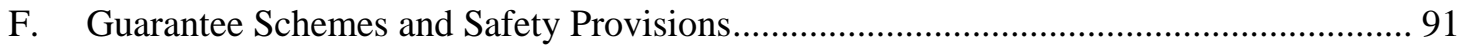

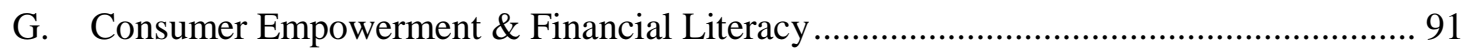

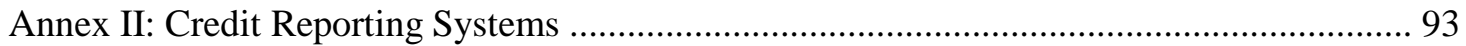

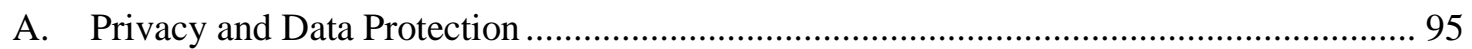

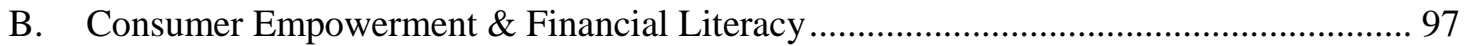

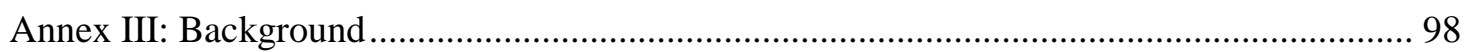

I. Financial Consumer Protection and Global Financial Regulation ................................ 98

II. Designing Financial Consumer Protection Programs................................................. 100

III. Design of the Good Practices for Financial Consumer Protection .................................. 104

IV. Possible Areas for Future Work by the International Community ................................ 107

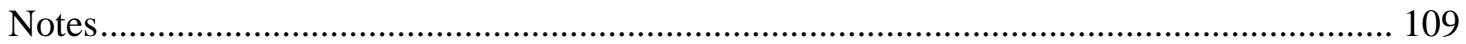

\section{List of Tables}

Table 1: WBG Country Diagnostic Reviews of Consumer Protection and Financial Literacy....... 3

Table 2: Overview of Consumer Protection Regulation for the Banking Sector .......................... 36

Table 3: Overview of Consumer Protection Regulation for the Securities Sector ....................... 49

Table 4: Selected Key Readings on Consumer Protection for the Insurance Sector ...................... 51

Table 5: Selected Codes of Conduct for the Insurance Sector ....................................................... 53

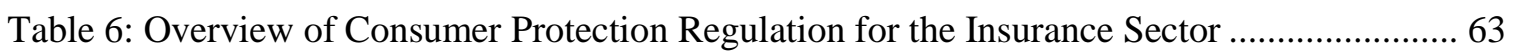

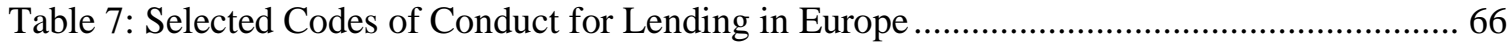

Table 8: Overview of Consumer Protection Regulation for Non-Bank Credit Institutions .......... 80

Table 9: Overview of Consumer Protection Regulation for Credit Reporting Systems................ 93

\section{List of Boxes}

Box 1: Measures to Ensure Success of Financial Education Programs....................................... 104 


\section{Chapter 1: Introduction}

Until the financial crisis of 2007-09, the global economy was adding an estimated 150 million new consumers of financial services each year. Rates of increase have since slowed but growth continues apace. The financial crisis highlighted the importance of financial consumer protection for the long-term stability of the global financial system. At the same time, rapid increases in the use of financial services have pointed to the need for strengthened financial regulation and consumer education to protect and empower consumers. In the absence of strong financial consumer protection, the growth-enhancing benefits of expanded financial inclusion may be lost or severely undermined.

Financial consumer protection ${ }^{1}$ sets clear rules of conduct for financial firms regarding their retail customers. It aims to ensure that consumers: (1) receive information to allow them to make informed decisions, (2) are not subject to unfair or deceptive practices and (3) have access to recourse mechanisms to resolve disputes. Complementary financial literacy initiatives are aimed at giving consumers the knowledge and skills to understand the risks and rewards of using financial products and services - and their legal rights and obligations in using them. Clear rules of conduct for financial institutions, combined with programs of financial education for consumers, will increase consumer trust in financial markets and will support the development of these markets.

The international community has recently increased its focus on financial consumer protection with the release of the G20 High Level Principles. Regulators have noted the pressing need for a set of guidelines of market conduct against which existing policies, laws and regulations, institutions and initiatives can be measured and assessed. The lack of recognized guidelines has often led policymakers to focus on only a few of the many consumer protection issues while failing to close gaps in other areas. During their February 2011 meeting, the Group of 20's Finance Ministers and Central Bank Governors called on the Organisation for Economic Co-operation and Development (OECD), the Financial Stability Board (FSB) and relevant international organizations to develop common principles on consumer protection in financial services in time for their October 2011 meeting. $^{2}$ In October 2011, the G20 ${ }^{3}$ released its HighLevel Principles on Financial Consumer Protection ${ }^{4}$ and ongoing work by the OECD Task Force on Financial Consumer Protection continues. (The first version of the Good Practices for Financial Consumer Protection was published prior to the release of the High Level Principles for Financial Consumer Protection. However the Good Practices complement the High Level Principles and provide practical advice on ways to implement the concepts within the Principles.)

Numerous other initiatives are also underway to strengthen financial consumer protection by international government organizations. In November 2010, the G20 Leaders also asked the FSB to work with the OECD and other international organizations to explore options to advance consumer finance protection. ${ }^{5}$ In October 2011, the FSB published its report on Consumer Finance Protection with particular focus on credit. ${ }^{6}$ Also starting in 2005, the OECD developed Recommendations on Good Practices for Financial Education and Awareness as well as specific good practices on financial education and awareness relating to credit, insurance and private pensions. ${ }^{7}$ In addition, the OECD has issued numerous working papers and other reports on financial literacy and financial education, including the 2012 Working Paper on Current Status of National Strategies for Financial Education: A Comparative Analysis and Relevant Practices. ${ }^{8}$ In Europe in addition to the Directives related to consumer finance, the European Commission has 
conducted studies on retail financial services, including retail investment advice, consumer credit, distance marketing of financial services, mortgages and consumer education in financial services. ${ }^{9}$ In November 2011, the European Insurance and Occupational Pensions Authority launched a public consultation on proposed Guidelines on Complaints-Handling by Insurance Undertakings. ${ }^{10}$ The Inter-American Development Bank supports the strengthening of financial consumer protection in various projects. ${ }^{11}$ In addition, the Government of the Russian Federation has provided a \$15 million Financial Literacy and Financial Education Trust Fund, administered by the World Bank and the OECD, to: (1) develop methodologies for measuring the financial capabilities of a variety of groups in developing countries, (2) test and refine these methods through their application in a range of existing programs in Bank client countries and (3) disseminate information on best practices in financial literacy ${ }^{12}$ measurement and enhancement through websites, workshops and other means. Initial reports from the Trust Fund will be disseminated starting in late 2012.

International and regional non-government organizations are also playing an increasingly important role in financial consumer protection. The Responsible Finance Forum lists financial consumer protection regulation and financial capability as two of the three pillars of the framework for Responsible Finance. ${ }^{13}$ In January 2012, the Association of Supervisors of Banks of the Americas (ASBA) released its draft paper on Supervision and Consumer Protection Best Practices and Recommendations. The 2011 Maya Declaration on Financial Inclusion recognizes consumer protection and empowerment as "key pillars of financial inclusion efforts to ensure that all people are included in their country's financial sector". ${ }^{14}$ Also in 2011 the Alliance for Financial Inclusion launched the Consumer Empowerment and Market Conduct Working Group to discuss emerging policy and regulatory issues about consumer protection and review empowerment measures that promote financial access and improve the quality of financial inclusion. Consumers International has released recommendations on financial consumer protection, including a call for international standards and guidelines as well as development of an international organization to share best practice and support the development of standards and guidelines. ${ }^{15}$ In addition, the International Organization for Standardization (ISO) Committee on consumer policy (ISO/COPOLCO) is in the process of developing a proposal to develop new international standards on consumer financial disclosure, particularly on mobile telephone-based financial services and international remittances. ${ }^{16}$ On financial literacy, in 2008 the OECD created the International Network on Financial Education, ${ }^{17}$ which brings together policy-makers working on financial education worldwide. Consumers International and Microfinance Opportunities together have developed a handbook to assist consumer advocates in their work on financial counseling. ${ }^{18}$ This summary is not exhaustive but helps illustrate the many ongoing international initiatives that support financial consumer protection. All the initiatives are helpful in strengthening the global response to weaknesses in financial consumer protection. Nevertheless, still more could be done by civil society organizations, particularly those operating at a global level.

The World Bank is also supporting the international dialogue on financial consumer protection through development of Good Practices based on country-level experience and ongoing technical assistance. The World Bank's Good Practices are based on in-depth countrylevel reviews of consumer protection and financial literacy. Initially developed in 2006 at the request of the Czech Republic, Good Practices for Consumer Protection and Financial Literacy in Europe and Central Asia have been used as an assessment tool for country diagnostic reviews. These Good Practices were largely based on developments in a number of countries that had begun to address consumer protection in retail financial markets. Subsequently, in November 2010, the World Bank launched a Global Program for Consumer Protection and Financial 
Literacy. As noted in Table 1, as part of the Global Program, a total of 18 country reviews have been completed as of the date of this publication. Supporting and complementing the country reviews are additional country-level technical assistance, including three country action plans, two implementation programs and 18 household surveys of financial literacy and consumer behavior, including the household surveys financed by the Russian Trust Fund. ${ }^{19}$ In addition, the World Bank has approved a total of \$28 million in loans and credits for consumer protection and financial literacy programs two countries (Russian Federation and Malawi). ${ }^{20}$

Table 1: WBG Country Diagnostic Reviews of Consumer Protection and Financial Literacy

\begin{tabular}{|lc|lc|}
\hline Country & Year of Publication & Country & Year of Publication \\
\hline Czech Republic & 2007 & Bosnia \& Herzegovina & Planned 2012 \\
\hline Slovakia & 2007 & Kazakhstan & Planned 2012 \\
\hline Bulgaria & 2009 & Malawi & Planned 2012 \\
\hline Romania & 2009 & South Africa & Planned 2012 \\
\hline Lithuania & 2009 & Nicaragua & Planned 2012 \\
\hline Azerbaijan & 2009 & Ukraine & Planned 2012 \\
\hline Croatia & 2010 & Armenia & Planned 2012 \\
\hline Russian Federation & 2010 & Mozambique & Planned 2013 \\
\hline Latvia & 2010 & Tajikistan & Planned 2013 \\
\hline
\end{tabular}

The Good Practices are intended to be used primarily as a diagnostic tool. The Good Practices provide a useful reference point for preparation of the country diagnostic reviews and thus assist policy-makers in answering the question, "How does the country's legal and regulatory framework for financial consumer protection compare to international practice?" Since no country is starting from scratch, a compilation of helpful approaches worldwide may help identify opportunities for specific countries in strengthening financial consumer protection. In this respect, the Good Practices provide concrete, evidence-based methods of strengthening financial consumer protection. Using the country-level experience of the World Bank Group in strengthening financial consumer protection and relying on international approaches that appear to work well in practice, the Good Practices for Financial Consumer Protection present a practical approach that regulators can use in their efforts to strengthen consumer protection in financial services. The Good Practices are not intended to be "best practice" worldwide. Rather they are a compilation of the most frequently used practices that have been successfully carried out in the field. They thus represent a rough summary of useful approaches in encouraging the improvement of conduct of financial institutions in dealing with their retail customers. It is hoped that the Good Practices will contribute to the evolving global dialogue on what constitute effective approaches to improving financial consumer protection in any country context.

The Good Practices provide a comprehensive diagnostic tool to help identify the consumer protection issues in all parts of the financial sector. The Good Practices are not intended to supersede benchmarks, guidelines, principles or good practices of any sector-specific international organization. Rather the Good Practices focus solely on issues related to consumer protection (and market conduct generally) across all financial services and complement the sector-specific guidance. Most importantly, the Good Practices help policy-makers in identifying cross-cutting consumer protection issues in the various parts of the financial sector and thus assist them in designing coherent, comprehensive and coordinated regimes for the improvement of consumer protection in the financial system. The need for a comprehensive approach to consumer protection is highlighted by the integration of many financial institutions into conglomerates. 
The Good Practices for Financial Consumer Protection reflect more than six years' work in development by the World Bank Group. As already noted, the Good Practices have now been tested in 18 countries worldwide (14 middle-income countries and four low-income countries). ${ }^{21}$ Further testing will continue for reviews to be conducted elsewhere in Africa (particularly subSaharan Africa), as well as in Asia, Latin America and the Caribbean, where innovations in the delivery of financial services will likely provide valuable lessons learned for countries worldwide. Other World Bank Group activities have also been incorporated into the Good Practices. These include studies on financial literacy and financial education through the Development Economics Research Group, ${ }^{22}$ the Human Development Network, the Financial Inclusion Practice (including the Micro \& SME Finance and Financial Infrastructure Service Lines), ${ }^{23}$ the Legal Department, and units providing access-to-finance advisory and investment services throughout the International Finance Corporation. ${ }^{24}$ In addition, the Good Practices incorporate key lessons from the work of Consultative Group to Assist the Poor (CGAP), a policy and research center housed at the World Bank that supports the development of, and related consumer protection issues for, the microfinance sector. ${ }^{25}$

The Good Practices have been formulated with input from existing international benchmarks and other accepted Good Practices developed by a wide range of organizations. They include the good/best practices, principles, benchmarks and recommendations of the United Nations, OECD, the European Commission, the Asia-Pacific Economic Cooperation forum, the Bank for International Settlements, the International Association of Insurance Supervisors, International Organisation of Pension Supervisors, the International Organization of Securities Commissions, and the G20 on Principles for Innovative Financial Inclusion. From all of these, recommendations related to consumer protection have been selected and brought together.

The Good Practices incorporate both the approaches of developed countries and the experiences of reforming emerging economies. Over the last 30 years, most programs on financial consumer protection have been undertaken in industrialized countries. However in recent years, valuable work has been conducted in developing countries and emerging markets, notably Brazil, China, Colombia, India, Malaysia, Mexico, Peru, Russia, and South Africa. As effective approaches become evident from countries worldwide, they will be incorporated into future revisions of the Good Practices.

The Good Practices have been subject to substantial international review and comment. In addition to rigorous testing at the country level, the Good Practices have benefitted from extensive international comment over several years. The Good Practices were first publicly released as a Consultative Draft, Good Practices for Consumer Protection and Financial Literacy in Europe and Central Asia: A Diagnostic Tool in August 2008 and they were finalized in August 2010. ${ }^{26}$ Subsequently, the Good Practices were revised and updated to reflect recent developments in financial consumer protection as well as insights from additional country reviews in Latin America and Africa. Good Practices for Financial Consumer Protection were then released as Consultative Draft in March 2011. During the consultation period, the Good Practices were presented and discussed at numerous international conferences, including the World Bank Group-CGAP conference in Washington D.C. in September 2008, a cross-regional video-dialogue (Development Debates) hosted by the World Bank Institute in February 2011, the annual meeting of FinCoNet in Toronto in May 2011 and the World Congress of Consumers International in Hong Kong also in May 2011. As noted in the Acknowledgements, over 25 regulators worldwide have also provided written comments, which have been incorporated into the final draft. 
Four important points are worth noting at the outset. First, the Good Practices apply only to a country's regulated financial system and not to informal financial services, such as loan sharking. Second, not all of the Good Practices are expected to be applied in full in all countries. Implementation of the Good Practices should inevitably be tailored to relevant country-specific needs and objectives. Third, the Good Practices do not cover an exhaustive list of financial products and services. Instead, they set out suggestions for consumer protection regarding only the most commonly used financial products and services. Fourth, the Good Practices are expected to further evolve and develop based on future country diagnostic reviews as well as the principles, practices, policy papers and seminars of international and national organizations, including those from non-government organizations.

Good Practices for Financial Consumer Protection is presented in three chapters. Chapter 1 provides an introduction, summarizing the international context for the development of the Good Practices and the methodology used in their development. Chapter 2 proposes 39 common Good Practices that apply across the spectrum of consumer financial services and may provide useful input into further development of international principles for financial consumer protection. Chapter 3 presents a set of Good Practices for each of four main types of financial services, namely banking, securities, insurance and non-bank credit. Annexes I and II present Good Practices for Private Pensions and Credit Reporting, both of which are still in the early stages of development. Annex III provides a background note covering: (1) the context underlying the growing importance of consumer protection in the financial regulatory agenda of all countries, (2) the rationale and underlying principles applied in designing consumer protection frameworks in any country context, (3) issues in the design of the Good Practices and (4) areas for possible future work in financial consumer protection by the international community. 


\section{Chapter 2: Common Good Practices for Financial Consumer Protection}

A well-functioning consumer protection regime provides effective safeguards for retail financial services consumers while empowering consumers to exercise their legal rights and fulfill their legal obligations. Summarized below are 39 basic Good Practices found in a wellfunctioning financial consumer protection regime.

\section{Consumer Protection Institutions}

1. The law provides clear consumer protection rules regarding financial products and services. The necessary institutional arrangements are in place to ensure thorough, objective, timely, and fair implementation (and enforcement) of the rules.

2. Codes of conduct for sector-specific financial institutions are developed by the sectorspecific association (in consultation with the financial supervisory agency and consumer associations, if possible). Monitored by statutory agencies or effective self-regulatory agencies, these codes are formally adhered to by all sector-specific institutions. The codes may be augmented by voluntary codes of conduct devised by individual financial institutions for their own operations. The codes are widely publicized.

3. Prudential supervision and consumer protection supervision may be placed in separate agencies or lodged in a single institution. However regardless of the institutional structure, the allocation of resources between prudential supervision and consumer protection is adequate to enable the effective implementation of consumer protection rules.

4. All legal entities that provide financial services to consumers are licensed (or registered) and supervised with regard to their market conduct (i.e. their business practices in relation to retail customers) by the appropriate financial supervisory authority.

5. The judicial system ensures that the ultimate resolution of any consumer protection dispute regarding a financial product or service is affordable, timely and delivered in a professional manner.

6. The media and consumer associations actively promote financial consumer protection.

\section{Disclosure and Sales Practices}

7. Before a financial institution makes a recommendation to a consumer regarding a specific financial product or service, it gathers sufficient information from the customer to ensure that the product or service is likely to meet the needs and capacity of that consumer.

8. For all financial products or services, consumers receive a short one or two page summary statement (or electronic equivalent), presented in a legible font and written in plain language, describing the key terms and conditions, including recourse mechanisms, applicable to the financial product or service. Summaries are based on industry-agreed standards for the minimum types of information to be published for each type of financial 
product or service - and allow easy comparison among financial service providers. Summaries are distributed by financial institutions.

9. Before a consumer purchases a financial product or service, the financial institution provides a written copy of the institution's general terms and conditions, as well as the specific terms and conditions that apply to the product or service.

10. The law specifically prohibits the use of fraudulent sales practices, such as misleading advertising, in the marketing of financial products and services.

11. Except for securities and derivatives, financial products or services with a long-term savings component - or those subject to high-pressure sales practices - have a "coolingoff" period, during which the consumer may cancel the contract without penalty. Nothing prevents a financial institution from recovering any processing fees incurred.

12. Whenever an individual borrower is obliged by a financial institution to purchase a product or service as a pre-condition for receiving another product or service, the borrower is free to choose the provider for the product or service.

13. In their advertising, financial institutions disclose that they are regulated and the advertising materials identify the relevant regulatory or supervisory agency.

14. Staff of financial institutions who deal directly with consumers receive adequate training, suitable for the complexity of the products or services they sell. In particular, financial intermediaries are qualified as appropriate for the complexity of the financial product or service they sell.

\section{Customer Account Handling and Maintenance}

15. Financial institutions prepare regular statements for each customer account regarding key details of customer financial transactions as well as written (or electronic) confirmations of the terms of each transaction. For investment products, customers receive periodic statements of the value of the assets in their account.

16. As early as possible, customers are individually notified in writing (or by electronic means) of changes in interest rates, fees, and charges or other key terms and conditions of their financial products or services.

17. Financial institutions maintain up-to-date customer records and provide customers with ready access to their records, either without charge or for a reasonable fee.

18. Clearing and settlement of retail payments is based on clear statutory and regulatory rules - or is subject to effective self-regulatory arrangements.

19. Financial institutions are prohibited from employing abusive collection or debt recovery practices against their customers. 


\section{Privacy and Data Protection}

20. For credit registries, the law specifies the extent and timeliness of the updating of customer information, gives customers ready and free access to their credit reports from credit registers (at least once a year), and provides procedures for correcting mistakes in credit reports.

21. Financial institutions are required to protect the confidentiality and technical security of customer data. The law states specific rules and procedures concerning the release of customer records to any government authority.

22. The law provides consumer rights regarding information sharing, including access, rectification, blocking and erasing of errors, and outdated personal information. The law also sets out basic rules of information sharing among participants of the credit reporting system, including credit registers, reporting institutions, and users of credit reports.

23. Every financial institution informs each of its customers of its policies for the use and sharing of the customer's personal information.

24. Credit bureaus are subject to oversight by the appropriate government (or nongovernment) authority.

\section{Dispute Resolution Mechanisms}

25. Every financial institution has a designated contact point with clear procedures for handling customer complaints, including complaints submitted verbally. Financial institutions also maintain up-to-date records of all complaints they receive and develop internal dispute resolution policies and practices, including processing time deadlines, complaint response, and customer access.

26. Consumers have access to an affordable, efficient, respected, professionally qualified and adequately resourced mechanism for dispute resolution, such as an independent financial ombudsman or equivalent institution with effective enforcement capacity. The institution acts impartially and independently from the appointing authority, the industry, the institution with which the complaint has been lodged, the consumer, and the consumer association. Decisions by the financial ombudsman or equivalent institution are binding on the financial institution.

27. Statistics of customer complaints, including those related to breaches of codes of conduct, are periodically compiled and published by the ombudsman or financial supervisory authority. The complaints are compiled by product type to facilitate identification of patterns and opportunities for improvements of service.

28. Regulatory agencies are legally obliged to publish aggregate statistics and analyses related to their activities regarding consumer protection - and propose regulatory changes or financial education measures to avoid the sources of systemic consumer complaints. Industry associations also play a role in analyzing the complaint statistics and proposing measures to avoid recurrence of systemic consumer complaints. 


\section{Guarantee and Compensation Schemes}

29. The law provides that the regulator can take appropriate measures to protect consumers in the event of financial distress of a financial institution.

30. Any law on financial insurance or a guarantee fund is clear on the insurer, the classes of depositors who are insured, the extent of insurance coverage, the contributor(s) to the fund, each event that will trigger a payout, and the mechanisms to ensure timely payout to all insured persons.

31. Depositors, life insurance policyholders, securities and derivatives account holders, and pension fund members enjoy higher priority than other unsecured creditors in the liquidation process of a relevant financial institution.

\section{Financial Literacy \& Consumer Empowerment}

32. A broad-based program of financial education and information is developed to increase the financial literacy of the population.

33. A wide range of organizations (including government, state agencies and nongovernmental organization) are involved in developing and implementing the financial literacy program. The government appoints a ministry (e.g. the Ministry of Finance), the central bank or a financial regulator to lead and coordinate the development and implementation of the program.

34. Initiatives are undertaken to improve financial literacy of consumers of all ages. This includes encouraging the mass media to cover issues related to consumer finance, including consumer protection in financial services.

35. Government and state agencies consult consumers, industry associations and financial institutions to develop proposals that meet consumers' needs and expectations. They also undertake consumer testing to try to ensure that proposed initiatives, including those regarding pre-contractual consumer disclosure and dispute resolution, are likely to have their intended outcomes.

36. The financial literacy of consumers and the impact of consumer empowerment measures are measured through broad-based household surveys that are repeated from time to time to see if the current policies are having the desired impact on the financial marketplace.

\section{Competition}

37. Financial regulators and competition authorities consult with one another.

38. Competition policy in financial services considers the impact of competition issues on consumer welfare, and especially planned or actual limits on choice.

39. Competition authorities conduct and publish periodic assessments of competition among retail financial institutions and make recommendations on how competition among retail financial institutions can be optimized. 


\section{Chapter 3: Good Practices for Financial Consumer Protection by Financial Service}

\section{BANKING SECTOR}

Good business relationships between commercial banks and the public are crucial for the development of any country's banking system. Needed are mutual trust and confidence between banks and consumers. To the extent that transparent pricing is absent, consumer awareness and protection is inadequate, or dispute resolution mechanisms are costly or ineffective, banking systems are less efficient and accessible than they would otherwise be.

A full assessment of the banking sector and the environment in which it operates is critical to determine whether some of the practices listed below are relevant for a particular country. These practices have been distilled from various sources, including prevailing and accepted practices in countries reputed to have good consumer protection in the banking sector. The Good Practices also draw on the international Good Practices and standards wherever applicable and appropriate. ${ }^{27}$ It is important to note that the practices have been crafted to enable their use in both countries with well-developed banking systems and those with less-developed systems. To ensure the usefulness of these Good Practices, a certain degree of generalization and a minimum requirement approach has been taken. The fundamental rights of the common consumer vis-à-vis the banking system are thereby preserved, while relevance in the context of the country concerned is also ensured.

\section{A. Consumer Protection Institutions}

\section{A.1. Consumer Protection Regime}

The law should provide clear consumer protection rules regarding banking products and services, and all institutional arrangements should be in place to ensure the thorough, objective, timely and fair implementation and enforcement of all such rules.

a. Specific statutory provisions should create an effective regime for the protection of a consumer of any banking product or service.

b. A general consumer agency, a financial supervisory agency or a specialized financial consumer agency should be responsible for implementing, overseeing and enforcing consumer protection regarding banking products and services, as well as for collecting and analyzing data (including inquiries, complaints and disputes).

c. The designated agency should be funded adequately to enable it to carry out its mandates efficiently and effectively.

d. The work of the designated agency should be carried out with transparency, accountability and integrity.

e. There should be co-ordination and co-operation between the various institutions mandated to implement, oversee and enforce consumer protection and financial system regulation and supervision.

f. The law should also provide for, or at least not prohibit, a role for the private sector, including voluntary consumer organizations and self-regulatory organizations, in respect of consumer protection regarding banking products and services. 
The legal foundation for recognizing, implementing, overseeing and enforcing consumer protection is the primary prerequisite for any legal rights, including consumer rights in banking. Similarly, supervision and enforcement of the protection of consumer affairs in the financial system is critical for ensuring consumer protection. In this regard, the assessments carried out so far and the experience of countries around the world clearly support the view that it is necessary to have an agency dedicated to overseeing and enforcing consumer protection.

The right to form voluntary organizations is taken for granted in many countries. Voluntary consumer associations and self- regulatory organizations are important pillars in the consumer protection regime. Their role should be recognized in the law in order to provide them with legitimacy and enable them to obtain funding or gather resources. The role of the private sector is also emphasized to provide legitimacy to banks so that they can participate in activities that would otherwise be considered non- banking matters and to enable them to allocate sufficient funding for financial literacy and related consumer protection pursuits.

International and national guidelines have been consulted for the development of this Good Practice. They include: EU Directive on Credit Agreements for Consumers, 2008/48/EC, repealing Directive 87/102/EEC; EU Directive on Consumer Protection in the Indication of the Prices of Products offered to Consumers, 1998/6/EC; EU Directive on the Distance Marketing of Consumer Financial Services, 2002/65/EC; the US Truth in Lending and Truth in Savings Acts; and the UK Financial Services and Markets Act of 2000 (which set up the Financial Services Authority). ${ }^{28}$

\section{A.2. Code of Conduct for Banks}

a. There should be a principles-based code of conduct for banks that is devised by all banks or the banking association in consultation with the financial supervisory agency and consumer associations, if possible. Monitored by a statutory agency or an effective self-regulatory agency, this code should be formally adhered to by all sector-specific institutions.

b. If a principles-based code of conduct exists, it should be publicized and disseminated to the general public.

c. The principles-based code should be augmented by voluntary codes of conduct for banks on such matters as facilitating the easy switching of consumers' current accounts and establishing a common terminology in the banking industry for the description of banks' charges, services and products.

d. Every such voluntary code should likewise be publicized and disseminated.

Many banking associations around the world adopt codes of conduct to inform the public of the services and standard of services to be expected from the industry. In most cases, the associations adopt lists of grand statements that are not relevant to the average customer, whereas specific principles-based voluntary codes of conduct generally have a positive impact on consumer protection. These codes use plain language and provide commitments that are clear to the average customer. The codes should be widely disseminated and published on the websites of banks, clearly indicating banks' commitments to comply with them.

Most banking associations operating in the EU have not adopted principles-based codes of banking practices. The reason may be that the EU directives on credit and provision of other financial services are detailed enough to ensure Good Practices. However, codes of banking practices have been adopted and enforced by many developed countries, such as Australia, Canada, New Zealand and the United Kingdom, as well as by the Special Administrative Region of China known as Hong Kong, and by some middle-income countries such as South Africa. 
These codes are principles-based and their compliance is monitored by the regulatory authority in the case of Hong Kong or subject to the jurisdiction of the ombudsman, in the case of South Africa and Australia. ${ }^{29}$

The codes generally comprise the following:

- Governing principles and objectives of the code

- The banking ombudsman scheme and mechanisms to deal with complaints

- Good business conduct relating to communication, privacy and disclosure

- Product and services

- Issues relating to checks

- Issues on provision of credit

- PINs and passwords

- Cards, liability and merchant card services

- Internet banking

- Other services such as foreign exchange services

- Statements and account information

\section{A.3. Appropriate Allocation between Prudential Supervision and Consumer Protection}

Whether prudential supervision of banks and consumer protection regarding banking products and services are the responsibility of one organization or two institutions, the allocation of resources to these functions should be adequate to enable their effective implementation.

The oversight of a code of conduct or consumer protection is not generally seen as being part of the responsibilities of banking supervisors. The laws of central banks or banking supervisory agencies typically contain no reference to "consumer protection" as a function of the banking supervisor or to the concepts of "fairness" and "transparency". However, consumer protection issues should not be ignored by regulators. If a bank provides an unsuitable or unfair service, this may damage its reputation, as well as customer loyalty and confidence. This may also indicate weaknesses in management and internal controls and expose the bank to financial loss, e.g. as a result of "mis-selling" of investment products. Thus, a banking regulator does have an interest in encouraging standards of good banking practice, whereby banks act fairly and reasonably in relation to their customers. The regulator, however, has to determine where to draw the line and, in particular, has to be careful about intervening in matters that are best dealt with through competitive market forces or resolved through courts. Banking regulators are very often better placed than a third party to strike the balance and avoid undue regulatory burden on the industry.

\section{A.4. Other Institutional Arrangements}

a. The judicial system should ensure that the ultimate resolution of any dispute regarding a consumer protection matter in respect of a banking product or service is affordable, timely and professionally delivered.

b. The media and consumer associations should play an active role in promoting banking consumer protection.

As the ultimate bastion of justice, the judiciary should be an effective final arbiter. For any consumer complaint about a banking product or service, the courts should be widely recognized as capable of rendering a final and binding decision in a professional, timely and cost effective manner. 
Media and consumer associations play an active role in promoting financial consumer protection in many countries. Proper media coverage of consumer mistreatment by financial institutions is an effective tool in promoting consumer protection through "naming and shaming". However, it is important that journalists be educated to understand and transmit information on financial issues accurately and adequately. In most European countries, there are consumer associations that deal with financial services. ${ }^{30}$ If, as in Article 7 of Decision No. 20/2004/EC, specific criteria are fulfilled, the organization might be even supported financially by the EU. Furthermore, the EC has created several consultative bodies, such as the Financial Services Consumer Group; and its permanent committees include representatives of consumer organizations from each of the EU Member States. They are specifically asked to ensure that consumer interests are properly taken into account in the formulation of EU financial services policy.

\section{A.5. Licensing}

All banking institutions that provide financial services to consumers should be subject to a licensing and regulatory regime to ensure their financial safety and soundness and effective delivery of financial services.

This good practice forms the basis and foundation for the enforcement of consumer protection in the banking system (see Basel Core Principle 3). The licensing authority should have the power to set criteria and reject applications for establishments that do not meet the standards set. Apart from licensing, ongoing regulation and supervision of the activities of the banking institution and its manner of delivering its services need also to be regulated. In most countries, banking services are regarded as essential and, as such, appropriate regulatory and supervisory arrangements should be in place.

\section{B. Disclosure and Sales Practices}

\section{B.1. Information on Customers}

a. When making a recommendation to a consumer, a bank should gather, file and record sufficient information from the consumer to enable the bank to render an appropriate product or service to that consumer.

b. The extent of information the bank gathers regarding a consumer should:

i. be commensurate with the nature and complexity of the product or service either being proposed to or sought by the consumer; and

ii. enable the bank to provide a professional service to the consumer in accordance with that consumer's capacity.

This is a basic requirement not only for the delivery of services but also for the purposes of complying with the Basel Core Principle $18^{31}$ issued by the Bank for International Settlements (BIS) and with the standards issued by the Financial Action Task Force (FATF). The FATF is an inter-governmental body created for the purpose of combating money laundering and terrorism financing. The FATF Standards comprise Forty Recommendations on Money Laundering and Nine Special Recommendations on Terrorist Financing. ${ }^{32}$

Accurate and reliable customer identification is important for more than FATF-related issues but can present a special challenge for low-income countries where national ID cards have not yet been issued. Some banks, for example in India and Malawi, use biometric measures to identify customers. In the case of banking transactions conducted through mobile telephones create their own rules regarding reliable customer identification. 


\section{B.2. Affordability}

a. When a bank makes a recommendation regarding a product or service to a consumer, the product or service it offers to that consumer should be in line with the need of the consumer.

b. The consumer should be given a range of options to choose from to meet his or her requirements.

c. Sufficient information on the product or service should be provided to the consumer to enable him or her to select the most suitable and affordable product or service.

d. When offering a new credit product or service significantly increasing the amount of debt assumed by the consumer, the consumer's credit worthiness should be properly assessed.

This good practice aims to avoid consumer over-indebtedness and to help consumers make appropriate decisions on their financial needs. It is not uncommon for consumer protection agencies to call on financial service providers to treat customers fairly, make sure that consumers can afford the credit they receive and, if not, ensure that they contact their lender or a free independent advice agency immediately. ${ }^{33}$ The EU Directive on Unfair Terms in Consumer Contracts 1993/13/EEC and EU Directive on Credit Agreements for Consumers, 2008/48/EC provide guidance regarding this Good Practice.

Particularly in low-income countries, affordability may also be related to concerns over possible over-indebtedness. In some countries, lenders such as microfinance institutions are not required to ask borrowers about other outstanding debts-or such debts may not be registered in the credit bureau system. The result may be consumers who become over-indebted, relying on one loan to pay off another. In Peru, the regulator has issued Regulation 6941-2008 (Rules for administration of over-indebtedness risk of retail debtors) to ensure that consumers do not use easy access to credit cards or other forms of credit to become over-indebted.

\section{B.3. Cooling-off Period}

a. For financial products or services with a long-term savings component, or those subject to high-pressure sales contracts, (unless explicitly waived in advance by a consumer in writing), a bank should provide the consumer a cooling-off period of a reasonable number of days (at least 3-5 business days) immediately following the signing of any agreement between the bank and the consumer.

b. On his or her written notice to the bank during the cooling-off period, the consumer should be permitted to cancel or treat the agreement as null and void without penalty to the consumer of any kind.

This important safeguard enables an individual to withdraw from an arrangement with impunity. This is particularly important for financial products or services with a long-term savings component-or those subject to high-pressure sales practices. Borrowers tend to rush into financial arrangements with their banks that provide seemingly attractive terms or returns without the benefit of shopping around. This is especially serious in countries where the terms of services and products are not readily available or cannot be compared. Thus, the cooling-off period provides relief similar to a "no-questions-asked" return policy for goods. However, for banking products and services that involve market risk, a consumer who cancels his or her contract during the cooling-off period should be required to compensate the bank for any processing fees. For a description of cooling-off periods in several EU Member States, see the EC's Discussion Paper for the amendment of the Directive 87/102/EEC concerning consumer credit. ${ }^{34}$ 


\section{B.4. Bundling and Tying Clauses}

a. As much as possible, banks should avoid bundling services and products and the use of tying clauses in contracts that restrict the choice of consumers.

b. In particular, whenever a borrower is obliged by a bank to purchase any product, including an insurance policy, as a pre-condition for receiving a loan from the bank, the borrower should be free to choose the provider of the product and this information should be made known to the borrower.

Tying occurs when two or more products are sold together in a package and at least one of these products is not sold separately. Market surveys suggest that in most EU Member States, the majority of banks tie a current account to mortgages, personal loans and SME loans ${ }^{35}$. Product tying in retail banking may weaken competition. First, tying raises costs and therefore is likely to reduce customer mobility. Second, by binding customers into buying several products from the same bank, tying is likely to discourage the entry of new players and growth of smaller players. Third, by introducing additional and perhaps unnecessary products into the transaction, tying reduces price transparency and comparability among providers. Product tying by one or more undertakings in a particular EU Member State may constitute an exclusionary abuse of dominance under Article 102 of the Treaty establishing the European Community (EC Treaty), where such undertakings have a dominant position.

Bundling occurs when two or more products are sold together in a package, although each of the products can also be purchased separately on the market. Firms bundle for several reasons (including economies of scope, price discrimination, demand management or leverage of market power into other market segments). Bundling is not per se anti-competitive and it can even have positive effects on the consumer (if the price of bundled services is lower than for unbundled ones, and if convenience is increased). However, bundling also has the potential to render price comparisons impossible, thus hindering competition. Also customers might be forced to accept services and products that they do not need and thus they would have to incur in fees and other costs associated with maintaining the bundled product or service.

\section{B.5. Preservation of Rights}

Except where permitted by applicable legislation, in any communication or agreement with a consumer, a bank should not exclude or restrict, or seek to exclude or restrict:

i. any duty to act with skill, care and diligence toward the consumer in connection with the provision by the bank of any financial service or product; or

ii. any liability arising from the bank's failure to exercise its duty to act with skill, care and diligence in the provision of any financial service or product to the consumer.

This good practice concerns the obligation to deal fairly and honestly with customers, and the right of privacy and data protection of consumers. This standard requires that consumers cannot be forced to accept contractual clauses that would reduce their rights. This is reflected in the Accountability Principle of the OECD Guidelines on the Protection of Privacy and Transborder Flows of Personal Data's (Paragraph 14), and the APEC Privacy Framework's Accountability Principle IX, which state that the data controller should be accountable for complying with the measures stated in the OECD and APEC guidelines.

The EU Directive on Unfair Business-to-Consumer Commercial Practices states that a commercial practice shall be deemed unfair if it is contrary to the requirements of professional diligence (Article 5). The Directive also indicates that a commercial practice is regarded as misleading if it omits material information that the average consumer needs in order to take a 
decision. One of several kinds of material information described in the Directive are "the arrangements for payment, delivery, performance and the complaint handling policy, if they depart from the requirements of professional diligence" (Article 7).

\section{B.6. Regulatory Status Disclosure}

In all of its advertising, whether by print, television, radio or otherwise, a bank should disclose the fact that it is a regulated entity and the name and contact details of the regulator.

This is in line with responsible and fair advertisement practices. The consumer should be able to verify the claims made by the advertiser. For example, see the UK Financial Services and Markets Act 2000 or the UK Consumer Credit Act 1974.

\section{B.7. Terms and Conditions}

a. Before a consumer opens a deposit, current (checking) or loan account at a bank, the bank should make available to the consumer a written copy of its general terms and conditions, as well as all terms and conditions that apply to the account to be opened. Collectively, these Terms and Conditions should include:

i. disclosure of details of the bank's general charges;

ii. a summary of the bank's complaints procedures;

iii. a statement regarding the existence of the office of banking ombudsman or equivalent institution and basic information relating to its process and procedures;

iv. information about any compensation scheme that the bank is a member of;

v. an outline of the action and remedies which the bank may take in the event of a default by the consumer;

vi. the principles-based code of conduct, if any, referred to in A.2 above;

vii. information on the methods of computing interest rates paid by or charged to the consumer, any relevant non-interest charges or fees related to the product offered to the consumer;

viii. any service charges to be paid by the consumer, restrictions, if any, on account transfers by the consumer, and the procedures for closing an account; and

ix. clear rules on the reporting procedures that the consumer should follow in the case of unauthorized transactions in general, and stolen cards in particular, as well as the bank's liability in such cases.

b. The Terms and Conditions should be written in plain language and in a font size and spacing that facilitates the reader's comprehension.

A number of international guidelines provide the background for this Good Practice, including the EU Directive on Credit Agreements for Consumers 2008/48/EC; the EU Directive on Consumer Credit 87/102/EEC; the EU Directive concerning Unfair Business-to-Consumer Commercial Practices in the Internal Market 2005/29/EC; the EU Directive on Misleading and Comparative Advertising 2006/114/EEC; the EU Directive on the Distance Marketing of Consumer Financial Services 2002/65/EC; the EU Directive on Protection of Consumers in Respect of Distance Contracts 1997/7/EEC; as well as the US Truth in Lending Act (TILA) and the Truth in Savings Act.

The purpose of TILA is to promote the informed use of consumer credit by requiring disclosures about its terms and by standardizing the manner in which costs associated with borrowing are calculated and disclosed. TILA also gives US consumers the right to cancel certain credit transactions that involve a lien on a consumer's principal dwelling, regulates certain credit card practices, and provides a means for fair and timely resolution of credit billing disputes. 
The US Truth in Savings Act requires clear and uniform disclosure of the rate of interest (annual percentage yield or APY) and fees that are associated with a savings account, so that the consumer is able to make a meaningful comparison between potential accounts. For example, a customer opening a certificate of deposit account should be provided with information about ladder rates (smaller interest rates with smaller deposits) and penalty fees for early withdrawal of a portion or all of the funds.

\section{B.8. Key Facts Statement}

a. A bank should have a summary statement, such as a Key Facts Statement, for each of its accounts, types of loans or other products or services and provide these to its customers and potential customers.

b. The summary statement should be written in plain language and summarize in a page or two the key terms and conditions of the specific banking product or service.

c. Prior to a consumer opening any account at, or signing any loan agreement with, the bank, the consumer should have delivered a signed statement to the bank to the effect that he or she has duly received, read and understood the relevant summary statement from the bank.

d. Summary statements throughout the banking sector should be written in such a way as to allow consumers the possibility of easily comparing products that are being offered by a range of banks.

A summary statement, such as a Key Facts Statement, provides consumers with simple and standard disclosure of key contractual information of a banking product or service, contributing to the consumers' better understanding of the product or service. Key Facts Statements also allow consumers to easily compare offers provided by different banks before they purchase a banking product or service. Such statements also provide a useful summary for later reference during the life of the financial product or service. For credit products, Key Facts Statements constitute an efficient way to inform consumers about their basic rights, the credit reporting systems and the existing possibilities for disputing information. This is of special importance in countries with new financial consumers who are inexperienced.

Several countries provide formats on Key Facts Statements. The UK FSA has developed mandatory key facts statements in the form of initial disclosure documents (or IDDs) applicable to housing credit products, including residential mortgage credit. IDDs are supported by a regulation on Mortgage: Conduct of Business (MCOB). The regulation provides recommendations for wording pre-disclosure and offering documents. In the European Union, the Directive on Credit Agreements for Consumers (2008/48/EC) includes a recommended format, namely the Standard European Consumer Credit Information (SECCI) form. Also the European Associations of Consumers and the European Credit Sector Associations have developed the European Standardized Information Sheet (ESIS) which provides a recommended format for pre-contractual information on home loans. In the US, the Truth in Lending Act (Appendix G-10) includes models for the "Schumer Box" for credit cards. ${ }^{36}$ Peru has developed the "Hoja Resumen" (Summary Sheet) ${ }^{37}$ and Ghana the "Pre-Agreement Truth in Lending Disclosure Statement" ${ }^{38}$ following similar key-fact-statement principles.

Of special concern in some countries is the need to provide basic information to consumers in a language that is widely used by local populations. For example, one of the largest banks in South Africa provides consumer information at its ATMs in six of the country's 11 official languages-but not in Afrikaans which is the third most common language spoken in the country. ${ }^{39}$ Similarly, in the Andean Region of Bolivia, Colombia, Ecuador and Peru, Quechua-not Spanish-is the 
language of many households. Likewise, in Malawi, although Chichewa is spoken by a majority of the population, little written banking information is available other than in English.

It may also be helpful to test consumer understanding of mandatory disclosure statements. In the US, the Federal Reserve Board has conducted extensive consumer testing of credit card disclosure information in order to develop an easily understood format. ${ }^{40}$

\section{B.9. Advertising and Sales Materials}

a. Banks should ensure that their advertising and sales materials and procedures do not mislead customers.

b. All advertising and sales materials of banks should be easily readable and understandable by the general public.

c. Banks should be legally responsible for all statements made in their advertising and sales materials (i.e. be subject to the penalties under the law for making any false or misleading statements).

For disclosure and sales practices, one of the main policy issues relates to misleading and comparative advertisement. Several directives in Europe hold financial institutions responsible for the content of their public announcements. These include the EU Directive on the Distance Marketing of Financial Services 2002/65/EC, the EU Directive on Misleading and Comparative Advertising 2006/114/EEC and the Unfair Commercial Practices Directive 2005/29/EEC.

Increasingly, in many developed and middle-income countries, banks use agents to market their products such as unit trusts and credit cards. These solicitations take place outside the bank premises-including at supermarkets and fairs. Thus, ensuring that banks are liable for the acts of their agents is critical.

\section{B.10. Third-Party Guarantees}

A bank should not advertise either an actual or future deposit or interest rate payable on a deposit as being guaranteed or partially guaranteed unless there is a legally enforceable agreement between the bank and a third party who or which has provided such a guarantee. In the event such an agreement exists, the advertisement should state:

i. the extent of the guarantee;

ii. the name and contact details of the party providing the guarantee; and

iii. in the event the party providing the guarantee is in any way connected to the bank, the precise nature of that relationship.

The word "guarantee" can be a persuasive element when it comes to "returns" on investment. There is a tendency, however, for the term to be used loosely. Furthermore, the actual terms of a guarantee can be difficult for the average customer to understand. Thus, advertisements should ensure that the fact of the third-party guarantee is clearly disclosed to the public so as to enable the consumer to make an informed decision about the usefulness or relevance of the guarantee.

\section{B.11. Professional Competence}

a. In order to avoid any misrepresentation of fact to a consumer, any bank staff member who deals directly with consumers, or who prepares bank advertisements (or other materials of the bank for external distribution), or who markets any service or product of the bank should be familiar with the legislative, regulatory and code of conduct guidance requirements relevant to his or her work, as well as with the details of any product or service of the bank which he or she sells or promotes. 
b. Regulators and associations of banks should collaborate to establish and administer minimum competency requirements for any bank staff member who: (i) deals directly with consumers, (ii) prepares any Key Facts Statement or any advertisement for the bank, or (iii) markets the bank's services and products.

The standard of professional delivery depends not only on the product or service but also on the knowledge and technical know-how of the individual delivering the product or service. Financial products are increasingly complicated, products overlap, and the delineation between banking and non-banking products is no longer clear. Thus, it is important that consumers fully understand any product, let alone a complex product before buying it. Typically, the banking industry is expected to ensure that its employees who deliver products and services are fully knowledgeable about these products and services and are able to explain the nuances to the consumer. In most cases, the industry sets competency standards through certification processes.

\section{Customer Account Handling and Maintenance}

\section{C.1. Statements}

a. Unless a bank receives a customer's prior signed authorization to the contrary, the bank should issue, and provide the customer free of charge, a monthly statement of every account the bank operates for the customer.

b. Each such statement should: (i) set out all transactions concerning the account during the period covered by the statement; and (ii) provide details of the interest rate(s) applied to the account during the period covered by the statement

c. Each credit card statement should set out the minimum payment required and the total interest cost that will accrue, if the cardholder makes only the required minimum payment.

d. Each mortgage or other loan account statement should clearly indicate the amount paid during the period covered by the statement, the total outstanding amount still owing, the allocation of payment to the principal and interest and, if applicable, the up-to-date accrual of taxes paid.

e. A bank should notify a customer of long periods of inactivity of any account of the customer and provide a reasonable final notice in writing to the customer if the funds are to be treated as unclaimed money.

f. When a customer signs up for paperless statements, such statements should be in an easy-toread and readily understandable format.

Statements from a bank can be regarded as the most valid record and evidence of a transaction for a customer. Thus, statements need to be self-explanatory and clear. They should allow the customer to comprehend the financial consequences of the "number" in the statement and take necessary action based on the statement. This is particularly important in the case of credit card statements and loan accounts statements that carry finance charges, penalty interest and serious consequences of default or delayed payment.

Banks should be obligated to provide monthly statements. However, with access to the internet and telephone banking, some customers may opt to receive statements on a quarterly basis. The choice should be left to the customers. Also, when customers choose paperless statements, the access to the statements, their format and details should be a fair substitute to paper statements.

\section{C.2. Notification of Changes in Interest Rates and Non-interest Charges}

a. A customer of a bank should be notified in writing by the bank of any change in: 
i. the interest rate to be paid or charged on any account of the customer as soon as possible; and

ii. a non-interest charge on any account of the customer a reasonable period in advance of the effective date of the change.

b. If the revised terms are not acceptable to the customer, he or she should have the right to exit the contract without penalty, provided such right is exercised within a reasonable period.

c. The bank should inform the customer of the foregoing right whenever a notice of change under paragraph a. is made by the bank.

Banks in many countries provide at least 1 to 3 months of notice depending on the agreement. In most countries, banks indicate in their offer documents and loan agreements whether the interest rate is fixed or variable and whether it is linked to a daily reference rate that is widely published such as LIBOR, etc. In such cases, the minimum notice that should be given in the event of a change in the interest rate should be agreed upfront. Interest rate increases that do not comply with the contractually stipulated notice are, therefore, invalid and will not be binding on the consumer. The code of conduct should include this requirement. A consumer's right to exit a contract is taken from Guidelines 17 and 19 of the UN Guidelines for Consumer Protection.

\section{C.3. Customer Records}

a. A bank should maintain up-to-date records in respect of each customer of the bank that contain the following:

i. a copy of all documents required to identify the customer and provide the customer's profile;

ii. the customer's address, telephone number and all other customer contact details;

iii. any information or document in connection with the customer that has been prepared in compliance with any statute, regulation or code of conduct;

iv. details of all products and services provided by the bank to the customer;

v. a copy of correspondence from the customer to the bank and vice-versa and details of any other information provided to the customer in relation to any product or service offered or provided to the customer;

vi. all documents and applications of the bank completed, signed and submitted to the bank by the customer;

vii. a copy of all original documents submitted by the customer in support of an application by the customer for the provision of a product or service by the bank; and viii. any other relevant information concerning the customer.

b. A law or regulation should provide the minimum permissible period for retaining all such records and, throughout this period, the customer should be provided ready access to all such records free of charge or for a reasonable fee.

While the above can be assumed in many countries, rudimentary banking systems often do not keep comprehensive information regarding customers and their transactions. The list may seem prescriptive but its requirements should be regarded as the minimum in order to ensure that sufficient information is kept for the purpose of providing customer protection. For more information, see annotation on good practice C.2.

\section{C.4. Paper and Electronic Checks}

a. The law and code of conduct should provide for clear rules on the issuance and clearing of paper checks that include, among other things, rules on:

i. checks drawn on an account that has insufficient funds;

ii. the consequences of issuing a check without sufficient funds; 
iii. the duration within which funds of a cleared check should be credited into the customer's account;

iv. the procedures on countermanding or stopping payment on a check by a customer;

v. charges by a bank on the issuance and clearance of checks;

vi. liability of the parties in the case of check fraud; and

vii. error resolution.

b. A customer should be told of the consequences of issuing a paper check without sufficient funds at the time the customer opens a checking account.

c. A bank should provide the customer with clear, easily accessible and understandable information regarding electronic checks, as well the cost of using them.

d. In respect of electronic or credit card checks, a bank should inform each customer in particular:

i. $\quad$ how the use of a credit card check differs from the use of a credit card;

ii. of the interest rate that applies and whether this differs from the rate charged for credit card purchases;

iii. when interest is charged and whether there is an interest free period, and if so, for how long;

iv. whether additional fees or charges apply and, if so, on what basis and to what extent; and

v. whether the protection afforded to the customer making a purchase using a credit card check differs from that afforded when using a credit card and, if so, the specific differences.

e. Credit card checks should not be sent to a consumer without the consumer's prior written consent.

f. There should be clear rules on procedures for dealing with authentication, error resolution and cases of fraud.

A number of international and national guidelines have been consulted regarding this Good Practice. These include the US Check Clearing for the 21st Century Act and important Codes of Banking Practices in Australia and South Africa. ${ }^{41}$ The check clearing house rules provide guidelines on this Good Practice. However, these rules are designed to guide banks and are not disclosed to the public. Thus, it is important that basic principles for bankers, such as the ones stated above, are followed by banks and customers are told of their rights and liabilities in these respects. ${ }^{42}$

The background for this Good Practice is provided by the EU Directive on Payment Services in the Internal Market 2007/64/EC, the US Regulation E and the BIS-World Bank's General Principles for International Remittance Services. However, the Good Practices do not cover the full range of payment/remittance services and providers. For completeness, see the full text of the General Principles. ${ }^{43}$ Equally relevant for an understanding of all the underlying payment system aspects are the CPSS-IOSCO Principles for Financial Market Infrastructures (2012) ${ }^{44}$, the CPSS General Guidance for National Payment System Development $(2006)^{45}$, and the World Bank General Guidelines for the Development of Government Payment Programs (consultative report, 2012). ${ }^{46}$

\section{C.5. Credit Cards}

a. There should be legal rules on the issuance of credit cards and related customer disclosure requirements. 
b. Banks, as credit card issuers, should ensure that personalized disclosure requirements are made in all credit card offers, including the fees and charges (including finance charges), credit limit, penalty interest rates and method of calculating the minimum monthly payment.

c. Banks should not be permitted to impose charges or fees on pre-approved credit cards that have not been accepted by the customer.

d. Consumers should be given personalized minimum payment warnings on each monthly statement and the total interest costs that will accrue if the cardholder makes only the requested minimum payment.

e. Among other things, the legal rules should also:

i. restrict or impose conditions on the issuance and marketing of credit cards to young adults who have no independent means of income;

ii. require reasonable notice of changes in fees and interest rates increase;

iii. prevent the application of new higher penalty interest rates to the entire existing balance, including past purchases made at a lower interest rate;

iv. limit fees that can be imposed, such as those charged when consumers exceed their credit limits;

v. prohibit a practice called "double-cycle billing" by which card issuers charge interest over two billing cycles rather than one;

vi. prevent credit card issuers from allocating monthly payments in ways that maximize interest charges to consumers; and

vii. limit up-front fees charged on sub-prime credit cards issued to individuals with bad credit.

f. There should be clear rules on error resolution, reporting of unauthorized transactions and of stolen cards, with the ensuing liability of the customer being made clear to the customer prior to his or her acceptance of the credit card.

g. Banks and issuers should conduct consumer awareness programs on the misuse of credit cards, credit card over- indebtedness and prevention of fraud.

Credit cards have become the common payment mechanism and are replacing hard currency in many countries. The credit card industry has also been in the limelight for its harmful practices, lack of transparency and of disclosure of terms and conditions of credit card accounts. This is particular problem in countries with low rates of savings and high consumer spending. The recent measures taken by many countries ${ }^{47}$ to update the rules applicable to credit cards clearly indicate the importance of consumer protection in these respects.

Consumers should get key information about credit card terms in a clear and conspicuous format and at a time when it is most useful to them. Anyone under 21 should get an adult to co-sign on the account if he or she wants to open his or her own credit card account or show proof that he or she has his or her own independent means to repay the card debt. Billing methods and information disclosed in the monthly statement should be clear and help customers to make informed choices on their indebtedness.

The increasing use of credit cards over the internet and outside the issuers' jurisdiction increases the incidence of stolen cards and fraud. Thus, improving consumer awareness and knowledge of these problems is important.

See also annotation on good practice C.4. 


\section{C.6. Internet Banking and Mobile Phone Banking}

a. The provision of internet banking and mobile phone banking (m-banking) should be supported by a sound legal and regulatory framework.

b. Regulators should ensure that banks or financial service providers providing internet and $\mathrm{m}$ banking have in place a security program that ensures:

i. data privacy, confidentiality and data integrity;

ii. authentication, identification of counterparties and access control;

iii. non-repudiation of transactions;

iv. a business continuity plan; and

v. the provision of sufficient notice when services are not available.

c. Banks should also implement an oversight program to monitor third-party control conditions and performance, especially when agents are used for carrying out m-banking.

d. A customer should be informed by the bank whether fees or charges apply for internet or mbanking and, if so, on what basis and how much.

e. There should be clear rules on the procedures for error resolution and fraud.

f. Authorities should encourage banks and service providers to undertake measures to increase consumer awareness regarding internet and m-banking transactions.

Internet and mobile phone banking improve a bank's efficiency and competitiveness in the provision of services and products. They allow existing and potential customers an increased degree of convenience in effecting banking and payment transactions. A bank may be faced with different levels of risks and expectations arising from internet and mobile phone banking as opposed to traditional banking. Furthermore, customers who rely on internet and mobile phone banking services may have greater intolerance for a system that is unreliable or one that does not provide accurate and current information.

Consumer protection should be ensured through rules that among other things: (i) limit systemic and other risks that could threaten the stability of financial markets or undermine confidence in the payment system; (ii) encourage institutions to educate customers about their rights and responsibilities and how to protect their own privacy on the Internet and when using mobile phones; and (iii) encourage the development of effective, low risk, low cost and convenient payment and financial services to customers and businesses through the Internet and by utilizing mobile phone banking.

See also annotation on good practice C.4.

\section{C.7. Electronic Fund Transfers and Remittances}

a. There should be clear rules on the rights, liabilities and responsibilities of the parties involved in any electronic fund transfer.

b. Banks should provide information to consumers on prices and service features of electronic fund transfers and remittances in easily accessible and understandable forms. As far as possible, this information should include:

i. the total price (e.g. fees for the sender and the receiver, foreign exchange rates and other costs);

ii. the time it will take the funds to reach the receiver;

iii. the locations of the access points for sender and receiver; and

iv. the terms and conditions of electronic fund transfer services that apply to the customer. 
c. To ensure transparency, it should be made clear to the sender if the price or other aspects of the service vary according to different circumstances, and the bank should disclose this information without imposing any requirements on the consumer.

d. A bank that sends or receives an electronic fund transfer or remittance should document all essential information regarding the transfer and make this available to the customer who sends or receives the transfer or remittance without charge and on demand.

e. There should be clear, publicly available and easily applicable procedures in cases of errors and frauds in respect of electronic fund transfers and remittances.

f. A customer should be informed of the terms and condition of the use of credit/debit cards outside the country including the foreign transaction fees and foreign exchange rates that may be applicable.

The rise in international and domestic remittance calls for greater protection in this area. The fees to be charged, the time taken for the funds to reach the beneficiary, and recourse mechanism procedures are some of the key issues that need to be reviewed. See also annotation on good practice C.4.

\section{C.8. Debt Recovery}

a. A bank, agent of a bank and any third party should be prohibited from employing any abusive debt collection practice against any customer of the bank, including the use of any false statement, any unfair practice or the giving of false credit information to others.

b. The type of debt that can be collected on behalf of a bank, the person who can collect any such debt and the manner in which that debt can be collected should be indicated to the customer of the bank when the credit agreement giving rise to the debt is entered into between the bank and the customer.

c. A debt collector should not contact any third party about a bank customer's debt without informing that party of the debt collector's right to do so; and the type of information that the debt collector is seeking.

d. Where sale or transfer of debt without borrower consent is allowed by law, the borrower should be:

i. notified of the sale or transfer within a reasonable number of days;

ii. informed that the borrower remains obligated on the debt; and

iii. provided with information as to where to make payment, as well as the purchaser's or transferee's contact information.

In a number of countries, weak safeguards against abusive debt collection: (i) strengthens the call for a more cumbersome recovery process; (ii) leads to moratoriums on collection; and (iii) earns the sympathy of courts. As a result, debt collection becomes a prolonged process that increases the cost of financing in the long-run. Sound rules on debt collection are required so as to help ensure that consumers are not subject to abusive and illegal collection practices.

While some countries rely on the sanctity of the contract and on the courts to uphold the right of borrower and to prevent abuses by lenders, other countries deal with this issue through the law, a directive of a regulator, or guidance provided by a consumer protection agency (see: the US Fair Debt Collection Practices Act, as well as the US Federal Trade Commission (FTC) and the UK Financial Services Authority (FSA) websites). ${ }^{48}$

\section{C.9. Foreclosure of mortgaged or charged property}

a. In the event that a bank exercises its right to foreclose on a property that serves as collateral for a loan, the bank should inform the consumer in writing in advance of the procedures 
involved, and the process to be employed by the bank to foreclose on the property it holds as collateral and the consequences thereof to the consumer.

b. At the same time, the bank should inform the consumer of the legal remedies and options available to him or her in respect of the foreclosure process.

c. If applicable, the bank should draw the consumer's attention to the fact that the bank has a legal right to recover the balance of the debt due in the event the proceeds from the sale of the foreclosed property are not sufficient to fully discharge the outstanding amount.

d. In the event the mortgage contract or charge agreement permits the bank to enforce the contract without court assistance, the bank should ensure that it employs professional and legal means to enforce the contract, including regarding the sale of the property.

The financial crisis of 2007-09 and its impact on Unites States' homeowners highlight the importance of ensuring a fair and adequate process in the foreclosure of mortgages. The subsequent legislative measures taken by the US government also underscore the dangers of inadequate safeguards in the foreclosure process. Many countries struggle to balance the rights of homeowners to keep their homes and the rights of banks to collect on defaulted loans. As a result, the pendulum swings between permitting out-of-court enforcement favoring banks and court foreclosures that favor borrowers. Regardless of the popular sentiment, it is important to have rules and procedures that ensure safeguards and due process in the enforcement of the rights of the party in a mortgage. Some of the key elements include sufficient notice and a fair and cost-effective process.

\section{C.10. Bankruptcy of Individuals ${ }^{49}$}

a. A bank should inform its individual customers in a timely manner and in writing on what basis the bank will seek to render a customer bankrupt, the steps it will take in this respect and the consequences of any individual's bankruptcy.

b. Every individual customer should be given adequate notice and information by his or her bank to enable the customer to avoid bankruptcy.

c. Either directly or through its association of banks, every bank should make counseling services available to customers who are bankrupt or likely to become bankrupt.

d. The law should enable an individual to:

i. declare his or her intention to present a debtor's petition for a declaration of bankruptcy;

ii. propose a debt agreement;

iii. propose a personal bankruptcy agreement; or

iv. enter into voluntary bankruptcy.

e. Any institution acting as the bankruptcy office or trustee responsible for the administration and regulation of the personal bankruptcy system should provide adequate information to consumers on their options to deal with their own debt and rehabilitation process in the event of bankruptcy.

Bankruptcy carries serious implications for an individual and can have a significant negative impact on his or her social and economic standing. In many countries, being declared bankrupt also entails travel restrictions and a prohibition on being named to official positions and participating in certain economic activities.

In some countries, customers of banks who default on their loans have little knowledge of the likelihood of being declared bankrupt and its consequences to their lives. In many countries, the process lacks transparency and a consumer may not even know that he or she has been declared bankrupt until his or her subsequent application for a credit has been turned down. By making 
counseling available to those who are likely to become bankrupt, consumers may be able to avoid bankruptcy or at least manage the process better. The law ought to also provide for rehabilitation process for bankrupt persons, if possible. ${ }^{50}$

\section{Privacy and Data Protection}

\section{D.1. Confidentiality and Security of Customers' Information}

a. The banking transactions of any bank customer should be kept confidential by his or her bank.

b. The law should require a bank to ensure that it protects the confidentiality and security of the personal data of its customers against any anticipated threats or hazards to the security or integrity of such information, as well as against unauthorized access.

The confidentiality of identifiable personal information is protected under several international guidelines and directives. These include the OECD Guidelines on the Protection of Privacy and Transborder Flows of Personal Data (Article 2 Scope of Guidelines), the EU Directive on the Protection of Individuals with regard to the Processing of Personal Data 1995/46/EC, and the APEC Privacy Framework (Part ii, Scope).

\section{D.2. Sharing Customer Information}

a. A bank should inform its customers in writing:

i. of any third-party dealing for which the bank is obliged to share information regarding any account of the customer, such as any legal enquiry by a credit bureau; and

ii. as to how it will use and share the customer's personal information.

b. Without the customer's prior written consent, a bank should not sell or share account or personal information regarding a customer of the bank to or with any party not affiliated with the bank for the purpose of telemarketing or direct mail marketing.

c. The law should allow a customer of a bank to stop or "opt out" of the sharing by the bank of certain information regarding the customer and, prior to any such sharing of information for the first time, every bank should be required to inform each of its customers in writing of his or her rights in this respect.

d. The law should prohibit the disclosure by a third party of any banking-specific information regarding a customer of a bank.

The EC creates legal security by publishing standardized clauses and model contracts (see Commission Staff Working Document on the Implementation of the Commission Decisions on Standard Contractual Clauses for the Transfer of Personal Data to Third Countries 2001/497/EC and 2002/16/EC). For information processing and sharing, this could serve as an example for a personal data protection agency.

\section{D.3. Permitted Disclosures}

The law should provide for:

i. the specific rules and procedures concerning the release to any government authority of the records of any customer of a bank;

ii. rules on what the government authority may and may not do with any such records;

iii. the exceptions, if any, that apply to these rules and procedures; and

iv. the penalties for the bank and any government authority for any breach of these rules and procedures. 
Each consumer should be informed in plain and understandable language about what can be disclosed by his or her bank before concluding any contract with the bank. This holds as well for all co-borrowers and personal guarantors. Again, the personal data protection agency should play an important role in educating the public about credit information sharing. Examples can be derived from the FTC and the UK Information Commissioner's Office (ICO).

\section{D.4. Credit Reporting}

a. Credit reporting should be subject to appropriate oversight, with sufficient enforcement authority.

b. The credit reporting system should have accurate, timely and sufficient data. The system should also maintain rigorous standards of security and reliability.

c. The overall legal and regulatory framework for the credit reporting system should be: (i) clear, predictable, non-discriminatory, proportionate and supportive of consumer rights; and (ii) supported by effective judicial or extrajudicial dispute resolution mechanisms.

d. In facilitating cross-border transfer of credit data, the credit reporting system should provide appropriate levels of protection.

e. Proportionate and supportive consumer rights should include the right of the consumer:

i. to consent to information-sharing based upon the knowledge of the institution's information-sharing practices;

ii. to access his or her credit report free of charge (at least once a year), subject to proper identification;

iii. to know about adverse action in credit decisions or less-than-optimal conditions/prices due to credit report information;

iv. to be informed about all inquiries within a period of time, such as six months;

v. to correct factually incorrect information or to have it deleted and to mark (flag) information that is in dispute;

vi. to reasonable retention periods of credit history, for instance two years for positive information and 5-7 years for negative information; and

vii. to have information kept confidential and with sufficient security measures in place to prevent unauthorized access, misuse of data, or loss or destruction of data.

f. The credit registries, regulators and associations of banks should undertake campaigns to inform and educate the public on the rights of consumers in the above respects, as well as the consequences of a negative personal credit history.

Credit reporting systems are designed to reduce credit risk and improve access to credit by keeping record of consumers' credit behavior. Transparency of credit reporting systems is important for good governance of these systems. At the same time, controls should exist to protect personal data. Credit reporting is becoming an ever more pervasive activity that affects a consumer's economic life by determining the extent of his or her access, if any, to finance and the terms of any eventual loan agreement that he or she may receive.

Public policy should find the right balance between consumer data protection and the economic rationale of processing personal information. The Good Practice incorporates the General Principles for Credit Reporting, developed by the Credit Reporting Standards Setting Task Force, coordinated by the World Bank. 


\section{E. Dispute Resolution Mechanisms}

\section{E.1. Internal Complaints Procedure}

a. Every bank should have in place a written complaints procedure and a designated contact point for the proper handling of any complaint from a customer, with a summary of this procedure forming part of the bank's Terms and Conditions referred to in B.7 above and an indication in the same Terms and Conditions of how a consumer can easily obtain the complete statement of the procedure.

b. Within a short period of time following the date a bank receives a complaint, it should:

i. acknowledge in writing to the customer/complainant the fact of its receipt of the complaint; and

ii. provide the complainant with the name of one or more individuals appointed by the bank to deal with the complaint until either the complaint is resolved or cannot be processed further within the bank.

c. The bank should provide the complainant with a regular written update on the progress of the investigation of the complaint at reasonable intervals of time.

d. Within a few business days of its completion of the investigation of the complaint, the bank should inform the customer/complainant in writing of the outcome of the investigation and, where applicable, explain the terms of any offer or settlement being made to the customer/complainant.

e. The bank should also inform the customer/complainant of the availability of the services of a financial ombuds service or other form of alternative dispute resolution.

f. When a bank receives a verbal complaint, it should offer the customer/complainant the opportunity to have the complaint treated by the bank as a written complaint in accordance with the above. A bank should not require, however, that a complaint be in writing.

g. A bank should maintain an up-to-date record of all complaints it has received and the action it has taken in dealing with them.

h. The record should contain the details of the complainant, the nature of the complaint, a copy of the bank's response(s), a copy of all other relevant correspondence or records, the action taken to resolve the complaint and whether resolution was achieved and, if so, on what basis.

i. The bank should make these records available for review by the banking supervisor or regulator when requested.

Internal complaints procedures act as the first line of possible relief for any aggrieved customer and ensure that disputes are resolved in-house as much as possible. Robust in-house complaints procedures improve customer relationships, increase trust in the banking system and reduce the cost of adjudication. Thus, they are important components of consumer protection.

Many banking supervisors deal with customer complaints based upon the code of conduct, if any, or through their general supervisory power. For instance, banking supervisors in Asia leave complaint forms in bank branches so that consumers will send their complaints directly to them. Some supervisors have a special unit dedicated to deal with consumer complaints against supervised banks, even if the objectives of the banking supervisor do not explicitly mention consumer protection as a mandate. Guidance on this Good Practice derives from the European Commission Recommendation on the principles for out-of-court bodies involved in the consensual resolution of consumer disputes, 2001/310/EC.

\section{E.2. Formal Dispute Settlement Mechanisms}

a. A system should be in place that allows customers of a bank to seek affordable and efficient recourse to a third-party banking ombudsman or equivalent institution, in the event the 
complaint of one or more of customers is not resolved in accordance with the procedures outlined in E.1 above.

b. The existence of the banking ombudsman or equivalent institution and basic information relating to the process and procedures should be made known in every bank's Terms and Conditions referred to in B.7 above.

c. Upon the request of any customer of a bank, the bank should make available to the customer the details of the banking ombudsman or equivalent institution, and its applicable processes and procedures, including the binding nature of decisions and the mechanisms to ensure the enforcement of decisions.

d. The banking ombudsman or equivalent institution should be appropriately resourced and discharge its function impartially.

e. The decision of the banking ombudsman or equivalent institution should be binding upon the bank against which the complaint has been lodged.

Few customers have the knowledge to realize that their rights have been infringed and, even if they are aware of the infringement, they typically have very few avenues to pursue their claims. Thus, as indicated in E.1 above, banks should be mandated to have an internal dispute resolution or complaint handling mechanism. Unless there are voluntary consumer associations that have the resources and skills to assist individuals with their complaints or legal actions against their banks, consumers do not have many venues to seek redress. The absence of small claims courts, as is the case in many countries, prevents an affordable means for the average customer to bring action against banks.

Thus, more and more banking systems around the world are seeking to establish an adequately resourced office of Ombudsman to deal expeditiously, independently, professionally and inexpensively with consumer disputes that do not get resolved internally by banks. The establishment and sustainability of such offices are now generally regarded as fundamental requirements for sound consumer protection. An Ombudsman can also identify complaints that are few in number but high in importance for consumer confidence in the financial system, thereby enabling the relevant authorities to take effective action to remedy the situation.

Without clear codes of conduct and standardized contracts, however, it becomes difficult for the Ombudsman's office to perform its role effectively. In many countries, the code of conduct (that is binding on all banks) forms the basis for the Ombudsman's jurisdiction and provides guidance in the resolution of disputes.

\section{E.3. Publication of Information on Consumer Complaints}

a. Statistics and data of customer complaints, including those related to a breach of any code of conduct of the banking industry should be periodically compiled and published by the ombudsman, financial supervisory authority or consumer protection agency.

b. Regulatory agencies should publish statistics and data and analyses related to their activities in respect of consumer protection regarding banking products and services so as, among other things, to reduce the sources of systemic consumer complaints and disputes.

c. Banking industry associations should also analyze the complaint statistics and data and propose measures to avoid the recurrence of systemic consumer complaints.

Apart from providing useful quantitative information, statistics also provide the tools needed for predictions and forecasting that form essential input for policy decision-making. However, the collection of statistics and data alone is not sufficient. Publication of the statistics and data is 
required to inform the public of common problems affecting consumers and to increase the knowledge and awareness of consumers.

By analyzing the statistics and data, regulators and banks can identify recurring problems and areas of weakness in banking practices. They can then take steps to deal with the source of the problems. The analysis is also critical for regulators to identify the correlation between the issues raised in the consumer complaints and systemic issues or weaknesses that may affect the soundness of the banking system itself.

\section{F. Guarantee Schemes and Insolvency}

\section{F.1. Depositor Protection}

a. The law should ensure that the regulator or supervisor can take necessary measures to protect depositors when a bank is unable to meet its obligations including the return of deposits.

b. If there is a law on deposit insurance, it should state clearly:

i. the insurer;

ii. the classes of those depositors who are insured;

iii. the extent of insurance coverage;

iv. the holder of all funds for payout purposes;

v. the contributor(s) to this fund;

vi. each event that will trigger a payout from this fund to any class of those insured;

vii. the mechanisms to ensure timely payout to depositors who are insured; and

viii. the circumstances when insured depositors would be denied payment of their deposits.

c. On an on-going basis, the deposit insurer should directly or through insured banks or the association of insured commercial banks, if any, promote public awareness of the deposit insurance system, as well as how the system works, including its benefits and limitations.

d. Public awareness should, among other things, educate the public on the financial instruments and institutions covered by deposit insurance, the coverage and limits of deposit insurance and the reimbursement process.

e. The deposit insurer should work closely with member banks and other safety-net participants to ensure consistency in the information provided to consumers and to maximize public awareness on an ongoing basis.

f. The deposit insurer should receive or conduct a regular evaluation of the effectiveness of its public awareness program or activities.

Policymakers have choices regarding how they can protect depositors and contribute to financial system stability. Explicit, limited-coverage deposit insurance (a deposit insurance system) has become the preferred choice compared to reliance on implicit protection. A deposit insurance system clarifies the authority's obligations to depositors, limits the scope for discretionary decisions, can promote public confidence, helps to contain the costs of resolving failed institutions, and can provide an orderly process for dealing with bank failures.

The introduction or the reform of a deposit insurance system can be more successful when a country's banking system is healthy and its institutional environment is sound. In order to be credible, a deposit insurance system needs to be part of a well-constructed financial system safety net, properly designed and well implemented. It also needs to be supported by strong prudential regulation and supervision, sound accounting and disclosure regimes, and the enforcement of effective laws. An effective deposit insurance system should also be supported by a high level of public awareness about its existence, its benefits and its limitations. A deposit insurance system 
should be able to deal with a limited number of simultaneous bank failures, but the resolution of a systemic banking crisis requires that all financial system safety-net participants work together effectively. The BIS Core Principle 23 issued in September 2005, the EU Directive on Deposit Guarantee Schemes 1994/19/EC, and the key conclusions of the APEC Policy Dialogue on Deposit Insurance in 2005 provide guidance for this Good Practice. ${ }^{51}$

\section{F.2. Insolvency}

a. Depositors should enjoy higher priority than other unsecured creditors in the liquidation process of a bank.

b. The law dealing with the insolvency of banks should provide for expeditious, cost effective and equitable provisions to enable the maximum timely refund of deposits to depositors.

The BIS Supervisory Guidance on Dealing with Weak Banks and other international guidelines stated in the annotation of F.1 above provide the background for this Good Practice.

\section{G. Consumer Empowerment \& Financial Literacy}

\section{G.1. Broadly based Financial Literacy Program}

a. A broadly based program of financial education and information should be developed to increase the financial literacy of the population.

b. A range of organizations, including those of the government, state agencies and nongovernment organizations, should be involved in developing and implementing the financial literacy program.

c. The government should appoint an institution such as the central bank or a financial regulator to lead and coordinate the development and implementation of the national financial literacy program.

Financial education, information and guidance can help consumers to budget and manage their income, to save, invest and protect themselves against risks, and to avoid becoming victims of financial fraud and scams. As financial products and services become more sophisticated and households assume greater responsibility for their financial affairs, it becomes increasingly important for individuals to manage their money well, not only to help secure their own and their family's financial well-being, but also to facilitate the smooth functioning of financial markets and the economy.

According to OECD analysis, many people have a poor understanding of the financial issues that affect their lives. OECD countries have agreed on new Good Practices on financial education relating to private pensions and insurance, which call on governments and businesses to work together to improve financial literacy in order to give people the tools they need to secure their future. ${ }^{52}$ Important conferences and seminars have been organized to raise awareness on this issue, including the International Conference on Financial Education (New Delhi, September 2006), the G8 Conference on Improving Financial Literacy (Moscow, November 2006), the International Seminar on Risk Awareness and Education on Insurance Issues (Istanbul, April 2007), the International Forum on Financial Consumer Protection and Education (Budapest, October 2007), the OECD-US Treasury International Conference on Financial Education (Washington, D.C., May 2008), the OECD-Bank Indonesia International Conference on Financial Education (Bali, October 2008), the OECD-IEFP Symposium on Financial Education (May 2009), the OECD-Brazilian International Conference on Financial Education (December 2009), the OECD-Reserve Bank of India Workshop on Delivering Financial Literacy: Challenges, Approaches and Instruments (Bangalore, March 2010), the OECD-Bank of Italy 
Symposium on Financial Literacy: Improving Financial Education Efficiency (Rome, June 2010), the OECD-Banque du Liban International Conference on Financial Education: Building Financially Empowered Individuals (Beirut, October 2010) and the FCAC-OECD Conference on Financial Literacy: Partnering to Turn Financial Literacy into Action (Toronto, May 2011). In order to assist policymakers, the OECD has established the International Gateway for Financial Education to describe, analyze and assess the effectiveness of programs to improve financial literacy.

The EU has also recognized the importance of improving people's financial literacy ${ }^{53}$. The term "financial literacy" means the ability to manage one's money, keep track of one's finances, plan ahead, choose appropriate financial products and services and stay informed about financial matters $^{54}$. Financial literacy initiatives are complementary to, not a substitute for, consumer protection regulation. The most effective ways of improving people's financial literacy vary according to factors such as their age, income level, educational attainment and culture. A range of approaches are needed which reflect the diversity of people's needs and aptitudes.

These approaches should focus on people's attitudes, as well as on financial education, information and skills. For example, it is not sufficient that people know how to save; they also need to understand the benefits that savings can bring them and their families, to recognize that it is worth deferring current expenditure, and to be motivated to set aside money on a regular basis. It is also important to cover basic issues such as budgeting, saving, planning ahead and choosing products, rather than merely to provide information about particular types of financial products and services.

There are many bodies - from government, state agencies and non-governmental organizations which have an interest in improving people's financial literacy. They should work together on this issue, so that there is a range of initiatives which, over time, will help to improve people's ability to manage their personal finances.

The government should appoint a ministry (for example, the Ministry of Finance), the central bank or a financial regulator to lead and coordinate the development and implementation of the national financial literacy program. This organization should provide drive and momentum; secure the active engagement of a broad range of other organizations; and ensure that priorities are identified and that unnecessary duplication is avoided, so that the most cost-effective use is made of available resources.

\section{G.2. Using a Range of Initiatives and Channels, including the Mass Media}

a. A range of initiatives should be undertaken by the relevant ministry or institution to improve people's financial literacy regarding banking products and services.

b. The mass media should be encouraged by the relevant ministry or institution to provide financial education, information and guidance to the public regarding banking products and services.

c. The government should provide appropriate incentives and encourage collaboration between governmental agencies, banking regulators, the banking industry and consumer associations in the provision of financial education, information and guidance regarding banking products and services.

A range of financial literacy initiatives should be developed. These can include: (i) financial education programs for schoolchildren;(ii) programs aimed at young people, such as university and college students;(iii) financial education presentations and other facilitated learning in 
workplaces and local communities (supported by "train the trainer" programs);(iv) publications and websites; and (v) television, radio and dramatic productions.

Financial education can be provided in schools so that schoolchildren gain the understanding, skills and confidence to manage their money as they take on responsibility for managing their own financial affairs. There is unlikely to be room in the curriculum for financial education to be included as a separate subject. However, financial education can be incorporated into other subjects, such as mathematics, life skills and citizenship curriculum.

Young people are more likely to find financial education engaging where it is interactive (for example, by involving research and problem-solving) and where it relates to issues they regard as relevant to their lives in the reasonably foreseeable future ${ }^{55}$. So, for example, older students are more likely to react positively to issues regarding saving for a holiday or for a car or to pay for their education, than issues relating to pensions or mortgages.

The media -particularly television and radio- can play an important role in providing financial education and information. Regulators and/or industry associations can support initiatives by providing the media with information about current concerns and about different types of financial services and products.

\section{G.3. Unbiased Information for Consumers}

a. Regulators and consumer associations should provide, via the internet and printed publications, independent information on the key features, benefits and risks -and where practicable the costs- of the main types of banking products and services.

b. The relevant authority or institution should encourage efforts to enable consumers to better understand the products and services being offered to consumers by banking institutions, such as providing comparative price information and undertaking educational campaigns.

c. The relevant authority or institution should adopt policies that encourage non-governmental organizations to provide consumer awareness programs to the public regarding banking products and services.

Consumers and potential consumers are more likely to have the confidence to purchase financial products and services which are suitable for them if they have access to information which is reliable and objective. Financial regulators are well-placed to provide this. For example, the UK Financial Services Authority's consumer website Money Made Clear includes information on a range of products ${ }^{56}$; provides a facility to download or order leaflets (which can also be ordered by telephone $)^{57}$; and includes impartial tables ${ }^{58}$ which people can use to compare the costs and some other features of similar financial products from different companies. In addition, global, regional and national data-bases of remittance prices provide valuable comparable information to consumers on the costs of sending remittances. ${ }^{59}$

\section{G.4. Consulting Consumers and the Financial Services Industry}

a. The relevant authority or institution should consult consumers, banking associations and banking institutions to help them develop financial literacy programs that meet banking consumers' needs and expectations.

b. The relevant authority or institution should also undertake consumer testing with a view to ensuring that proposed initiatives have their intended outcomes.

In developing financial literacy programs, consultations will be helpful in order to take into account the perspectives of consumers, as well as those of financial services firms and/or their 
trade associations. In countries where there are informed and effective consumer organizations, those organizations will naturally need also to be consulted.

To ensure that consumers are actively involved in the policy development process, it is recommended that the government or private sector organizations or both provide appropriate funding to non-governmental organizations for this purpose and create a special entity to lobby on behalf of consumers in the policy-making process.

It can also be very beneficial to test proposed initiatives with end-users (that is, a sample of the type of person that the initiative in question is intended to reach) to try to ensure that the initiative will have the intended impact. Among the techniques for doing so are the use of focus groups and pilot studies.

\section{G.5. Measuring the Impact of Financial Literacy Initiatives}

a. The financial literacy of consumers should be measured, amongst other things, by broadlybased household surveys and mystery shopping trips that are repeated from time to time.

b. The effectiveness of key financial literacy initiatives should be evaluated by the relevant authorities or institutions from time to time.

In order to measure the impact of financial education and information, the financial literacy of a sample of the population should be measured by means of large-scale market research that gets repeated from time to time. Initiatives will take some time to have a measurable impact on the financial literacy of a population, so it is likely to be sufficient to repeat the survey every four to five years.

In addition, key financial literacy initiatives should be evaluated to assess their impact on those people they are intended to reach. This can help policymakers and funders to decide, on an informed basis, which initiatives should be continued (and perhaps scaled up) and which should be modified or discontinued.

\section{H. Competition and Consumer Protection}

\section{H.1. Regulatory Policy and Competition Policy}

Regulators and competition authorities should be required to consult one another for the purpose of ensuring the establishment, application and enforcement of consistent policies regarding the regulation of financial services.

In many countries, general legislation, including consumer laws as well as the EU competition policy, requires protection of the economic interests of consumers. This includes, for instance, protection from misleading advertising and unfair contract terms. All business practices that restrict, prevent or distort competition are subject to scrutiny. ${ }^{60}$

\section{H.2. Review of Competition}

Given the significance of retail banking to the economy as a whole and to the welfare of consumers, competition authorities should:

i. monitor competition in retail banking;

ii. conduct, and publish for general consumption, periodic assessments of competition in retail banking (such as the range of interest rates across banks for specific products); and

iii. make recommendations publicly available on enhancing competition in retail banking. 
See annotation of good practice H.1 above.

Many international guidelines provide guidance for the development of this Good Practice including, the EC Treaty's Article 102; the EC's Sector Inquiry under Art 17 of Regulation 1/2003 on retail banking; the OECD's non-binding Recommendations on competition law and policy; as well as the OECD's Best Practices on information exchange in cartel investigations. The OECD's Recommendations and Best Practices are often catalysts for major change by governments (see Table 2 for an overview of these recommendations and best practices).

\section{H.3. Impact of Competition Policy on Consumer Protection}

The competition authority and the regulator should evaluate the impact of competition policies on consumer welfare, especially regarding any limitations on customer choice and collusion regarding interest and other charges and fees.

While competition authorities monitor the compliance of their policies and enforce them, not many of them carry out systematic evaluation of the impact of the policies on consumer welfare or well-being. Availability of choice and reasonable fees and charges increases the well-being of consumers. Unless the impact evaluation is done, the outcome of the competition policy cannot be measured. 
An overview of the main international and US and UK consumer protection legislation and regulation for the banking sector is presented in Table 2 .

Table 2: Overview of Consumer Protection Regulation for the Banking Sector

\begin{tabular}{|c|c|}
\hline $\begin{array}{l}\text { International } \\
\text { Institution or } \\
\text { National } \\
\text { Government }\end{array}$ & Laws, Regulations, Directives and Guidelines \\
\hline $\begin{array}{l}\text { BIS - Bank for } \\
\text { International } \\
\text { Settlements }\end{array}$ & $\begin{array}{l}\text { Basel Committee on Banking Supervision, Core Principles for Effective Banking } \\
\text { Supervision, September 1997, revised October } 2006 \\
\text { Supervisory Guidance on Dealing with Weak Banks, } 2002\end{array}$ \\
\hline BIS-World Bank & General Principles for International Remittance Services, 2007 \\
\hline United Nations & Guidelines for Consumer Protection (as expanded in 1999) \\
\hline $\begin{array}{l}\text { OECD - } \\
\text { Organisation for } \\
\text { Economic } \\
\text { Cooperation and } \\
\text { Development }\end{array}$ & $\begin{array}{l}\text { Guidelines on the Protection of Privacy and Transborder Flows of Personal Data, } \\
1980 \\
\text { Guiding Principles for Regulatory Quality and Performance, } 2005 \\
\text { Best Practices for the Formal Exchange of Information Between Competition } \\
\text { Authorities in Hard Core Cartel Investigations, } 2005 \\
\text { Recommendation of the Council concerning Merger Review, } 2005 \\
\text { Recommendation of the Council concerning Structural Separation in Regulated } \\
\text { Industries, } 2001 \\
\text { Recommendation of the Council concerning Effective Action against Hard Core } \\
\text { Cartels, } 1998 \\
\text { Recommendation of the Council concerning Co-operation between Member } \\
\text { Countries on Anticompetitive Practices affecting International Trade, } 1995\end{array}$ \\
\hline $\begin{array}{l}\text { APEC - Asia Pacific } \\
\text { Economic } \\
\text { Cooperation }\end{array}$ & $\begin{array}{l}\text { APEC Privacy Framework, } 2005 \\
\text { APEC Policy Dialogue on Deposit Insurance: Key Policy Conclusions, } 2004\end{array}$ \\
\hline $\begin{array}{l}\text { EU - European } \\
\text { Union }\end{array}$ & $\begin{array}{l}\text { Directive on Consumer Credit, 1987/102/EEC, as amended } \\
\text { Directive on Credit Agreements for Consumers, 2008/48/EC, repealing Directive } \\
\text { 87/102/EEC } \\
\text { Directive on Consumer Protection in the Indication of the Prices of Products } \\
\text { offered to Consumers, 1998/6/EC } \\
\text { Directive on Unfair Terms in Consumer Contracts, 1993/13/EEC } \\
\text { Directive concerning Unfair Business-to-Consumer Commercial Practices in the } \\
\text { Internal Market, 2005/29/EC } \\
\text { Directive on Misleading and Comparative Advertising, 2006/114/EEC } \\
\text { Directive on the Distance Marketing of Consumer Financial Services, } \\
\text { 2002/65/EC } \\
\text { Directive on Payment Services in the Internal Market, 2007/64/EC } \\
\text { Directive on Deposit Guarantee Schemes, 1994/19/EC } \\
\text { Directive on Protection of Consumers in Respect of Distance Contracts, } \\
\text { 1997/7/EC } \\
\text { Directive on the Protection of Individuals with regard to the Processing of } \\
\text { Personal Data and on the Free Movement of such data, 1995/46/EC } \\
\text { Commission Recommendation on the Principles for Out-of-court Bodies } \\
\text { involved in the Consensual Resolution of Consumer Disputes, 2001/310/EC } \\
\text { Communication from the Commission - Sector Inquiry under Art } 17 \text { of } \\
\text { Regulation } 1 / 2003 \text { on Retail Banking, COM (2007) 33 final }\end{array}$ \\
\hline
\end{tabular}




\begin{tabular}{|c|c|}
\hline $\begin{array}{l}\text { International } \\
\text { Institution or } \\
\text { National } \\
\text { Government }\end{array}$ & Laws, Regulations, Directives and Guidelines \\
\hline & Recommendation 1998/257/EC: out-of-court settlement of consumer disputes \\
\hline & Directive on Electronic Money 2009/110/EC \\
\hline & $\begin{array}{l}\text { Commission Staff Working Document on the Implementation of the Commission } \\
\text { Decisions on Standard Contractual Clauses for the Transfer of Personal Data to } \\
\text { Third Countries 2001/497/EC and 2002/16/EC, SEC (2006) } 95 \\
\text { Treaty establishing the European Community (EC Treaty), } 1957 \text { as amended }\end{array}$ \\
\hline $\begin{array}{l}\text { FATF - Financial } \\
\text { Action Task Force }\end{array}$ & $\begin{array}{l}\text { Forty Recommendations on Money Laundering, } 2003 \\
\text { Nine Special Recommendations on Terrorism Financing, } 2001 \text { as expanded in } \\
2004\end{array}$ \\
\hline $\begin{array}{l}\text { US - United States } \\
\text { of America }\end{array}$ & $\begin{array}{l}\text { Dodd-Frank Wall Street Reform and Consumer Protection Act, } 2010 \\
\text { Credit Card Accountability, Responsibility, and Disclosure Act of } 2009 \text { (Credit } \\
\text { CARD Act of 2009), } 2009 \\
\text { Truth in Lending Act (TILA), } 1968 \\
\text { Truth in Savings Act, } 1991 \\
\text { Check Clearing for the 21st Century Act, } 2003 \\
\text { Fair Debt Collection Practices Act, } 1977 \\
\text { Regulation E - Electronic Fund Transfers, } 1966 \\
\text { Federal Trade Commission Act, } 1914 \\
\text { Equal Credit Opportunity Act, } 1974\end{array}$ \\
\hline $\begin{array}{l}\text { UK - United } \\
\text { Kingdom }\end{array}$ & $\begin{array}{l}\text { Financial Services and Markets Act, } 2000 \\
\text { Consumer Credit Act, } 1974\end{array}$ \\
\hline World Bank & General Principles for Credit Reporting, 2011 \\
\hline
\end{tabular}




\section{SECURITIES SECTOR}

Consumer protection in the securities sector has been recognized as critical to the development of the depth and integrity of the securities ${ }^{61}$ markets for many years. The relationship between an entity providing investment services and products to customers, such as an intermediary, investment adviser or collective investment undertaking (CIU) ${ }^{62}$ and its customers is the basis for the fair, sound and efficient functioning of the securities markets. The maintenance and enforcement of the integrity of that relationship has been the subject of governmental regulatory action and international cooperation for many years and is the basis for the development of these Good Practices.

\section{A. Investor Protection Institutions}

\section{A.1. Consumer Protection Regime}

The law should provide for clear rules on investor protection in the area of securities markets products and services, and there should be adequate institutional arrangements for the implementation and enforcement of investor protection rules.

a. There should be specific legal provisions which create an effective regime for the protection of investors in securities.

b. There should be a governmental agency responsible for data collection and analysis (including complaints, disputes and inquiries) and for the oversight and enforcement of investor protection laws and regulations.

A general consensus has developed that investor/consumer protection in the securities markets requires a legal framework and should be regulated by a governmental agency. Source: IOSCO Principles 1-5.

\section{A.2. Code of Conduct for Securities Intermediaries, Investment Advisers and Collective Investment Undertakings}

a. Securities intermediaries, investment advisers and CIUs should have a voluntary code of conduct.

b. If such a code of conduct exists, securities intermediaries, investment advisers and CIUs should publicize the code to the general public through appropriate means.

c. Securities Intermediaries, Investment Advisers and CIUs should comply with the code and an appropriate mechanism should be in place to provide incentives to comply with the code.

In addition to the governmental regulation, market professionals in the securities market should have a code of conduct that can provide guidance for market professionals and a means by which their customers can evaluate them. Sources: IOSCO Rules 25-29; CESR Standard 10 and Rule 17; FINRA Manual incorporating NASD Rules Section 2000 Business Conduct and FIMM, Code of Ethics and Standards of Professional Conduct for the Unit Trust Industry.

\section{A.3. Other Institutional Arrangements}

a. The judicial system should provide an efficient and trusted venue for the enforcement of laws and regulations on investor protection.

b. The media should play an active role in promoting investor protection. 
c. The private sector, including voluntary investor protection organizations, industry associations and, where permitted, self-regulatory organizations should play an active role in promoting investor protection.

A fair and efficient judicial system is critical for the functioning of any regulatory system. An open and free discussion regarding the financial system in the information media is also critical for a full evaluation of the extent to which a financial system provides protection for investors. In addition, private sector organizations are an important means of disseminating information to consumers in a cost effective manner and should be encouraged within the context of the legal system. Sources: FINRA Manual incorporating NASD Rules Sections 2000 and 3000, and SEC Securities and Exchange Act of 1934 Section 15A.

\section{A.4. Licensing}

a. All legal entities or physical persons that, for the purpose of investment in financial instruments, solicit funds from the public should be obliged to obtain a license from the supervisory authority.

b. Legal entities or physical persons that give investment advice and hold customer assets should be licensed by the securities supervisory authority.

c. If a jurisdiction does not require licensing for legal entities or physical persons that give only investment advice, such persons should be supervised by an industry association or selfregulatory organization and the anti-fraud provisions of the securities laws or other consumer laws should apply to the activity of such persons.

A key measure in preventing the emergence of financial pyramids is the requirement for licensing of all entities that contact the public and solicit funds for investment or speculation. However, $a$ distinction should be made between private solicitations of friends and family versus a public solicitation to an indeterminate number of investors. For the latter, different jurisdictions use different thresholds to identify what is an "indeterminate number", but the threshold is generally between 15 and 50 investors. All persons, legal and physical, that solicit funds from more than 50 investors should be required to be registered with the financial supervisory agency and be obliged to obtain a license for their activities.

Legal entities and physical persons that provide investment advice but don't intermediate securities have become a serious issue for the protection of investors. If such persons hold customer assets, they should be licensed by the securities authority. If they only give advice, the oversight of such persons varies greatly between jurisdictions. A consensus has developed that there should be oversight and ethical standards for these persons. This can be done by securities authorities, self-regulatory organizations, or industry associations. In order for this oversight to be effective, at the least, such persons should be subject to the anti-fraud provisions of the securities and consumer protection laws.

\section{B. Disclosure and Sales Practices}

\section{B.1. General Practices}

There should be disclosure principles that cover an investor's relationship with a person offering to buy or sell securities, buying or selling securities, or providing investment advice, in all three stages of such relationship: pre-sale, point of sale, and post-sale.

a. The information available and provided to an investor should inform the investor of:

i. $\quad$ the choice of accounts, products and services;

ii. the characteristics of each type of account, product or service; 
iii. the risks and consequences of purchasing each type of account, product or service;

iv. the risks and consequences of using leverage, often called margin, in purchasing or selling securities or other financial products; and

v. the specific risks of investing in derivative products, such as options and futures.

b. A securities intermediary, investment adviser or CIU should be legally responsible for all statements made in marketing and sales materials related to its products.

c. A natural or legal person acting as the representative or tied-agent of a securities intermediary, investment adviser or CIU should disclose to an investor whether the person is licensed to act as such a representative and who licenses the person.

d. If a securities intermediary, investment adviser or CIU delegates or outsources any of its functions or activities to another legal entity or physical person, such delegation or outsourcing should be fully disclosed to the investor, including whether the person to whom such function or activity is delegated is licensed to act in such capacity and who licenses the person.

Disclosure of all relevant information to a customer of a securities intermediary, investment adviser or CIU is one of the most important aspects of consumer protection in the securities sector. Full information about the services provided to the customer is critical in giving the customer the ability to make an informed decision as to which intermediary, adviser or CIU to use. Sources: (a) IOSCO Principle 23 and Guidelines on Standards of Conduct for Financial Advisers and Representatives, Monetary Authority of Singapore; CESR Standards 37-39; (b) IOSCO Principle 1; (c) CESR Standard 35 and MiFID Article 19; and (d) SEC Form N-1A Registration of Open-Ended Investment Management Companies.

\section{B.2. Terms and Conditions}

a. Before commencing a relationship with an investor, a securities intermediary, investment adviser or CIU should provide the investor with a copy of its general terms and conditions, as well as any terms and conditions that apply to the particular account.

b. The terms and conditions should always be in a font size and spacing that facilitates easy reading.

c. The terms and conditions should disclose:

i. details of the general charges;

ii. the complaints procedure;

iii. information about any compensation scheme that the securities intermediary or CIU is a member of, and an outline of the action and remedies which the investor may take in the event of default by the securities intermediary or CIU;

iv. the methods of computing interest rates paid or charged;

v. any relevant non-interest charges or fees related to the product;

vi. any service charges;

vii. the details of the terms of any leverage or margin being offered to the client and how the leverage functions;

viii. any restrictions on account transfers; and

ix. the procedures for closing an account.

This sets out the general disclosure requirements of B.1. in more detail regarding the specific contract that the customer enters into. The point-of-sale disclosure is recognized as the critical moment in sales disclosure due to its immediate impact on the customer to make the decision to invest. Sources: IOSCO Principle 23, CESR Standards 78-79 and Rule 80, and MiFID Article 19. 


\section{B.3. Professional Competence}

Regulators should establish and administer minimum competency requirements for the sales staff of securities intermediaries, investment advisers and CIUs, and collaborate with industry associations where appropriate.

Since the sales person is the direct link between the intermediary, adviser or CIU and the customer, the sales persons should be properly qualified and knowledgeable about the products that they are selling. Sources: MiFID Article 9 (only requires managers of investment firms to be qualified) and FINRA Manual incorporating NASD Rules 1030-1032.

\section{B.4. Know Your Customer ${ }^{63}$}

Before providing a product or service to an investor, a securities intermediary, adviser or CIU should obtain, record and retain sufficient information to enable it to form a professional view of the investor's background, financial condition, investment experience and attitude toward risk in order to enable it to provide a recommendation, product or service appropriate to that investor.

There is a general consensus that a securities intermediary, investment adviser or CIU should obtain information from their customers so that they can deal with them in a manner appropriate to their circumstances. Sources: IOSCO Principle 23, CESR Standard 62 and Rules 63-70, MiFID Article 19 and FINRA Manual incorporating NASD Rule 2310.

\section{B.5. Suitability}

A securities intermediary, investment adviser or CIU should ensure that, taking into account the facts disclosed by the investor and other relevant facts about that investor of which it is aware, any recommendation, product or service offered to the investor is suitable to that investor.

There is a general consensus that a securities intermediary should warn customers that certain types of investments are not suitable for them based on their financial situation and investment goals. Sources: IOSCO Principle 23, CESR Standards 72-74 and Rules 75-77, MiFID Article 19 and FINRA Manual incorporating NASD Rule 2310 provide background for this Good Practice.

\section{B.6. Sales Practices}

a. Legislation and regulations should contain clear rules on improper sales practices in the solicitation, sale and purchase of securities. Thus, securities intermediaries, investment advisers, CIUs and their sales representatives should:

i. not use high-pressure sales tactics;

ii. not engage in misrepresentations and half-truths as to products being sold;

iii. fully disclose the risks of investing in a financial product being sold;

iv. not discount or disparage warnings or cautionary statements in written sales literature; and

v. not exclude or restrict, or seek to exclude or restrict, any legal liability or duty of care to an investor, except where permitted by applicable legislation.

b. Legislation and regulations should provide sanctions for improper sales practices.

c. The securities supervisory agency should have broad powers to investigate fraudulent schemes.

There is a general consensus that the obligation to deal fairly and honestly with customers includes the obligation to use sales practices that do not deceive, defraud or unduly pressure customers to make investment decisions. This obligation should be enforced with legal sanctions in order to make the obligation effective. Source: General duty IOSCO Principle 23 and MiFID 
Article 19. More specifically, for point (a) above, the following guidelines have been consulted: CESR Standard 18 Rule 23; CESR Standard 29 Rule 31 and FINRA Rule 2020; CESR Standards 51 and 52, Rules 53 and 54; and Code of Conduct for Persons Licensed by or Registered with the Securities and Futures Commission of Hong Kong 2010.

The securities supervisory agency should have broad powers to investigate Ponzi and other pyramid schemes and then assist the criminal authorities in prosecution. The law needs to identify a multi-level sales scheme as a pyramid scheme if: (1) the scheme requires a payment for the right to receive compensation for recruiting new salespersons into the plan; (2) there is inventory loading, that is, new salespersons should purchase an unreasonable quantity of a product or service; and (3) purchases of services are required as a condition of entry into the scheme. Sources: IOSCO Principles 8 and 12, CESR Standard 35.

\section{B.7. Advertising and Sales Materials}

a. All marketing and sales materials should be in plain language and understandable by the average investor.

b. Securities intermediaries, investment advisers, CIUs and their sales representatives should ensure their advertising and sales materials and procedures do not mislead the customers.

c. Securities intermediaries, investment advisers and CIUs should disclose in all advertising, including print, television and radio, the fact that they are regulated and by whom.

Disclosure of adequate information in advertising, marketing and sales materials is another important aspect of consumer protection in the securities sector. Sources: (a) CESR Standard 25; (b) CESR Standard 29 and Rule 31, FINRA Manual incorporating NASD Rule 2210, and Securities Board of India Chapter 13, Master Circular for Mutual Funds 2011; and (c) CESR Standard 35 and MiFID Article 19.

\section{B.8. Relationships and Conflicts}

a. A securities intermediary, investment adviser or CIU should disclose to its clients all relationships that it has which impact on the client's account, such as banks, custodians, advisers or intermediaries which are used to maintain and manage the account.

b. A securities intermediary, investment adviser or CIU should disclose all conflicts of interest that it has with the client and the manner in which the conflict is being managed.

In order for investors to evaluate the services being offered to them, there should be full transparency as to the identity of the market institutions that will have an impact on their account. To the extent that any of these institutions and legal entities and physical persons associated with them have conflicts with the investor, such conflicts and the manner in which they are being dealt with should be disclosed to the investor. Sources: SEC Investment Advisers Act Rule 204-3; EU UCITS Directive Article 14; EU MiFID Directive Article 18

\section{B.9. Specific Disclosures by CIUs}

a. CIUs should disclose to prospective and existing investors:

i. the CIU's policies with regard to frequent trading and the risks to investors from such policies;

ii. any inducements that it receives to use particular intermediaries or other financial firms, such as "soft-money" arrangements; and

iii. a fair and honest description of the performance of the CIU's investments over several different periods of time that accurately reflect the CIU's performance. 
b. In addition, a CIU should provide a Key Facts Statement for each fund that it is offering to the client that succinctly explains the fund in clear language. Such document is in addition to any other disclosure documents required by law.

The ability of clients to engage in frequent trading in a CIU can have an effect on long-term investors. A CIU's policies regarding such practices and the attendant risks would have an impact on an investor's decision to trade and should be disclosed to the investor. Source: SEC Form N-1A. (b) Inducements paid to a CIU or adviser to use market services, such as brokerage services, sometimes referred to as "soft-money: payments could create a conflict of interest and affect the ability of the CIU or adviser in giving impartial investment advice. Such relationships should be disclosed to investors to enable them to evaluate the services of the CIU or Adviser properly. Sources: EU MiFID Directive Article 26; SEC Investment Advisers Rule 204-3. (c) To avoid "cherry picking" the best performance periods for a CIU, performance should be given for several event-neutral periods of time to give an investor the ability to evaluate the CIU over short and long holding periods. Sources: SEC Form N-1A and Rule 482 under the Securities Act of 1933.

In order to give a clearer picture as to the goals, management and performance of a CIU, a general consensus has developed that a short, clear statement of key information should be given to an investor before purchasing or selling a share or unit of a CIU. Sources: EU UCITS Directive Article 78; SEC Form N-1A and Hong Kong SFC Handbook for Unit Trusts and Mutual Funds Chapter 6.

\section{B.10. Specific Disclosures by Investment Advisers}

a. Investment advisers should disclose to prospective and existing clients:

i. whether the investment adviser is also registered in another capacity and whether the adviser deals with the client's account in the second registered capacity; and

ii. whether the financial instruments that the investment adviser is recommending are held in the adviser's own inventory or the inventory of a legal or natural person related to the adviser--and if they will be bought from, or sold to, its own inventory or the inventory of a related party.

b. An investment adviser should provide prospective and existing clients with a Key Facts Statement for each product or service that is being offered or sold to the client that succinctly explains the product or service in clear language.

Many investment advisers have brokerage licenses in addition to their adviser's licenses and will deal with their advisee clients while in their capacity as a broker. This dual relationship should be disclosed to the client so that the client can evaluate the objectiveness of the advice given. Source: SEC Investment Advisers Act Section 206(3).

In order to provide a clear, concise statement as to the services that a provider is offering, a key facts statement as to the adviser's services and products should be given to the client to allow the client to make a well informed decision as to whether to engage the adviser. Source: MAS, Financial Advisers Act, Guidelines for Standards of Conduct of Financial Advisers and Representatives, Section 6. 


\section{Customer Account Handling and Maintenance}

\section{C.1. Segregation of Funds}

Funds of investors should be segregated from the funds of all other market participants.

In order to protect customer funds in the event of insolvency of a securities intermediary, investment adviser, CIU or other market participants, customer funds should be segregated from the assets of the intermediary, adviser or CIU in a manner to protect the assets from being a part of the bankruptcy estate of the intermediary, adviser and CIU. Sources: IOSCO Principle 23; MiFID Article 13 (7) and (8) that provide arrangements to safeguard client funds, but no statement of segregation; FINRA Manual incorporating NASD Rule 2330; and SEC Securities and Exchange Act of 1934 and Regulation 15c3-3 promulgated thereunder.

\section{C.2. Contract Note}

a. Investors should receive a detailed contract note from a securities intermediary or CIU confirming and containing the characteristics of each trade executed with them, or on their behalf.

b. The contract note should disclose the commission received by the securities intermediary, CIU and their sales representatives, as well as the total expense ratio (expressed as total expenses as a percentage of total assets purchased).

c. In addition, the contract note should indicate the trading venue where the transaction took place and whether (i) the intermediary for the transaction acted as a broker in the trade, (ii) the intermediary or CIU acted as the counterparty to its customer in the trade, or (iii) the trade was conducted internally in the intermediary between its clients.

Customers should have immediate information as to any transactions in their accounts as well as the terms of the transactions. This enables customers to verify whether the transaction was executed pursuant to the authorization given by the customer. Waiting for such information for a long time period reduces the ability of the customer and intermediary or CIU to correct any mistakes in the transaction. Sources: IOSCO Principle 23, CESR Standard 55 and Rules 58 and 59, FINRA Manual incorporating NASD Rule 2230, and SEC Investment Adviser Rule 206(3)-2.

\section{C.3. Statements}

a. An investor should receive periodic, streamlined statements for each account with a securities intermediary or CIU, providing the complete details of account activity in an easy-to-read format.

i. Timely delivery of periodic securities and CIU statements pertaining to the accounts should be made.

ii. Investors should have a means to dispute the accuracy of the transactions recorded in the statement within a stipulated period.

iii. When an investor signs up for paperless statements, such statements should also be in an easy-to-read and readily understandable format.

b. If a legal or natural person who provides only investment advice to customers also holds client assets, the client statements should be prepared by and sent from the custodian for the assets and not from the investment adviser.

Customers need access to the information regarding their accounts. Providing customers with regular statements on a periodic basis (depending on the activity in the account) has been generally accepted as the best means to provide this information. Sources: IOSCO Principle 23, 
CESR Standard 56 and Rule 59; FINRA Manual incorporating NASD Rule 2340; NASD Notice to Members 98-3 Electronic Delivery of Information between Members and their Customers.

Customers should have confidence that the information that an adviser is giving them is accurate. Consequently, the account statements for the customer accounts should be sent directly from the custodian of the funds to the clients to avoid the possibility of incorrect information being given to clients. Source: SEC Investment Advisers Act Rule 206(4)-2.

\section{C.4. Prompt Payment and Transfer of Funds}

When an investor requests the payment of funds in his or her account, or the transfer of funds and assets to another securities intermediary or CIU, the payment or transfer should be made promptly.

Investors may need immediate access to their funds in order to meet other financial and personal obligations. The delay in payment of account balances or the closing of accounts reduces confidence and the perception of the integrity of the securities markets. Sources: IOSCO Principle 23 and FINRA Manual incorporating NASD Rule 11870.

\section{C.5. Investor Records}

a. A securities intermediary, investment adviser or CIU should maintain up-to-date investor records containing at least the following:

i. a copy of all documents required for investor identification and profile;

ii. the investor's contact details;

iii. all contract notices and periodic statements provided to the investor;

iv. details of advice, products and services provided to the investor;

v. details of all information provided to the investor in relation to the advice, products and services provided to the investor;

vi. all correspondence with the investor;

vii. all documents or applications completed or signed by the investor;

viii. copies of all original documents submitted by the investor in support of an application for the provision of advice, products or services;

ix. all other information concerning the investor which the securities intermediary or CIU is required to keep by law;

$\mathrm{x}$. all other information which the securities intermediary or CIU obtains regarding the investor.

b. Details of individual transactions should be retained for a reasonable number of years after the date of the transaction. All other records required under a. to j. above should be retained for a reasonable number of years from the date the relationship with the investor ends. Investor records should be complete and readily accessible.

The maintenance of books and records is vital to the proper regulation of intermediaries, CIUs and other market participants, as well as the review of the events in individual customer accounts. Without the maintenance of these records, the regulatory system would be ineffective and customer protection would be minimized. Sources: IOSCO Principle 23; CESR Standard 10 Rule 15, requiring the retention of the details of transactions for 5 years after the date of the transaction; SEC Securities and Exchange Act of 1934, and Regulation 17a-3 thereunder; and FINRA Manual incorporating NASD Rule 3110. 


\section{Privacy and Data Protection}

\section{D.1. Confidentiality and Security of Customer's Information}

Investors of a securities intermediary, investment adviser or CIU have a right to expect that their financial activities will remain private and not subject to unwarranted private and governmental scrutiny. The law should require that securities intermediaries, investment advisers and CIUs take sufficient steps to protect the confidentiality and security of a customer's information against any anticipated threats or hazards to the security or integrity of such information, and against unauthorized access to, or use of, customer information.

A consensus has developed that customers have a right to financial privacy and to be free from unwarranted intrusions into their privacy. Because of the requirement for intermediaries and CIUs to know their customers, securities markets professionals often have some of the largest sources of information regarding the financial situation of their customers. Therefore, it is very important that the intermediaries and CIUs have an obligation to keep the financial information of their clients secure from unwarranted access by internal persons in the intermediary and CIU and from external persons. Sources: EU Directive Concerning Processing Personal Data and Protection of Privacy in the Electronic Communication Sector 2002/58/EC, and SEC Securities and Exchange Act of 1934 and Regulation S-P thereunder.

\section{D.2. Sharing Customer's Information}

Securities intermediaries, investment advisers and CIUs should:

i. inform an investor of third-party dealings in which they are required to share information regarding the investor's account, such as legal enquiries by a credit bureau, unless the law provides otherwise;

ii. explain how they use and share an investor's personal information;

iii. allow an investor to stop or "opt out" of certain information sharing, such as selling or sharing account or personal information to outside companies that are not affiliated with them, for the purpose of telemarketing or direct mail marketing, and inform the investor of this option.

Customers should be aware of how information can be shared with third parties and within the various units or subsidiaries of a financial conglomerate. Many of these shared uses can be beneficial for a customer, but a customer should have the right to stop or prohibit such information sharing if the customer does not find such information sharing to be useful or beneficial to him or her. Sources: EU Directive Concerning Processing Personal Data and Protection of Privacy in the Electronic Communication Sector 2002/58/EC, and SEC Securities and Exchange Act of 1934 and Regulation S-P thereunder.

\section{D.3. Permitted Disclosures}

a. If there are to be any specific procedures and exceptions concerning the release of customer financial records to government authorities, these procedures and exceptions should be stated in the law.

b. The law should provide for penalties for breach of investor confidentiality.

Governmental regulatory authorities have the need to obtain customer information for regulatory purposes and law enforcement purposes. The instances where this is permitted should be clearly stated in the law, as well as procedures for notification or situations where notification is not required. Enforcement for violation of the privacy rules has to be made effective by civil, administrative and criminal penalties, for violations of the law. Sources: EU Directive 
Concerning Processing Personal Data and Protection of Privacy in the Electronic Communication Sector 2002/58/EC, and SEC Securities and Exchange Act of 1934 and Regulation $S-P$ thereunder.

\section{E. Dispute Resolution Mechanisms}

\section{E.1. Internal Dispute Settlement}

a. An internal avenue for claim and dispute resolution practices within a securities intermediary, investment adviser or CIU should be required by the securities supervisory agency.

b. Securities intermediaries, investment advisers and CIUs should provide designated employees available to investors for inquiries and complaints.

c. Securities intermediaries, investment advisers and CIUs should inform their investors of the internal procedures on dispute resolution.

d. The securities supervisory agency should provide oversight on whether securities intermediaries, registered investment advisers and CIUs comply with their internal procedures on investor protection rules.

Many customer complaints come from misunderstandings or lack of information about their accounts, which can be cleared up internally with the intermediary, adviser and CIU. Efficient internal procedures should be in place to handle customer complaints fairly and quickly. Sources: IOSCO Principle 23; CESR Standard 78 Rule 80 where a procedure exists, such as arbitration; and IOSCO Principles 1-5.

\section{E.2. Formal Dispute Settlement Mechanisms}

There should be an independent dispute resolution system for resolving disputes that investors have with their securities intermediaries, investment advisers and CIUs.

a. A system should be in place to allow investors to seek third-party recourse, such as an ombudsman or arbitration court, in the event the complaint with their securities intermediary, investment adviser or CIU is not resolved to their satisfaction in accordance with internal procedure, and it should be made known to the public.

b. The independent dispute resolution system should be impartial and independent from the appointing authority and the industry.

c. The decisions of the independent dispute resolution system should be binding on the securities intermediaries and CIUs. The mechanisms to ensure the enforcement of these decisions should be established and publicized.

Retail investors frequently invest small sums and the expense of judicial processes can render any successful claim regarding those sums meaningless. Consequently, it is important for retail investors to have an alternate method of dispute resolution that is quick, efficient and inexpensive so that their rights can be enforced. Sources: MiFID Article 53 and FINRA Rule 12000 Code of Arbitration Procedure for Customer Disputes.

\section{F. Guarantee Schemes and Insolvency}

\section{F.1. Investor Protection}

a. There should be clear provisions in the law to ensure that the regulatory authority can take prompt corrective action on a timely basis in the event of distress at a securities intermediary, investment adviser or CIU.

b. The law on the investors' guarantee fund, if there is one, should be clear on the funds and financial instruments that are covered under the law. 
c. There should be an effective mechanism in place for the pay-out of funds and transfer of financial instruments by the guarantee fund or insolvency trustee in a timely manner.

d. The legal provisions on the insolvency of securities intermediaries, investment advisers and CIUs should provide for expeditious, cost-effective and equitable provisions to enable the timely payment of funds and transfer of financial instruments to investors by the insolvency trustee of a securities intermediary or CIU.

Customer funds should be protected in the event of the insolvency of intermediaries and CIUs where their funds are placed. The insolvency proceedings should provide for a fair and rapid mechanism for the pay out of customer funds. Where permitted by law, an investor guarantee fund can provide an independent, effective mechanism for ensuring that investor funds are protected and returned to them promptly. Sources: IOSCO Principle 24, EU Directive on Investor-Compensation Schemes, and SEC Securities Investor Protection Act of 1970.

\section{G. Consumer Empowerment \& Financial Literacy}

\section{G.1. Broadly based Financial literacy Program}

a. A broadly based program of financial education and information should be developed to increase the financial literacy of the population.

b. A range of organizations-including government, state agencies and non-governmental organizations-should be involved in developing and implementing the financial literacy program.

c. The government should appoint an institution such as the central bank or a financial regulator to lead and coordinate the development and implementation of the national financial literacy program.

Financial education, information and guidance can help consumers to budget and manage their income, to save, invest and protect themselves against risks, and to avoid becoming victims of financial fraud and scams. As financial products and services become more sophisticated and households assume greater responsibility for their financial affairs, it becomes increasingly important for individuals to manage their money well, not only to help secure their own and their family's financial well-being, but also to facilitate the smooth functioning of financial markets and the economy.

Many organizations in both the public and private sector have an interest in improving people's financial literacy. They should work together on this issue, so that there is a range of initiatives which, over time, will help to drive up people's ability to manage their personal finances.

\section{G.2. Using a Range of Initiatives and Channels, including the Mass Media}

a. A range of initiatives should be undertaken to improve people's financial literacy.

b. This should include encouraging the mass media to provide financial education, information and guidance.

People learn in different ways. The approaches and channels likely to be most effective will vary according to (among other things) people's age, income level, culture and the style of learning with which they are most comfortable. They are unlikely to absorb all relevant information and guidance the first time they see or hear it: providing the information a number of times, and in a variety of different ways, can help to reinforce key messages. 
The media is one of the most efficient means of providing education and ongoing information to customers regarding the state of the securities markets and market participants. The regulator should view the media as an effective means of communicating its regulatory activity to a broad cross-section of investors and should provide the media with open access to public, nonconfidential information for dissemination to the investing public.

\section{G.3. Unbiased Information for Investors}

a. Financial regulators should provide, via the internet and printed publications, independent information on the key features, benefits and risks - and where practicable the costs - of the main types of financial products and services.

b. Non-governmental organizations should be encouraged to provide consumer awareness programs to the public regarding financial products and services.

The regulator should take an active role in consumer education as part of its role to protect consumers. Consumers are better able to protect their interests and investments by making informed decisions prior to their investments, rather than engaging in litigation after an investment has gone awry. Source: IOSCO Principle 4.

\section{G.4. Measuring the Impact of Financial literacy Initiatives}

a. The financial literacy of consumers should be measured through a broad-based household survey that is repeated from time to time.

b. The effectiveness of key financial literacy initiatives should be evaluated.

The financial literacy of a sample of the population should be measured by means of a nationwide household survey that gets repeated from time to time (every four to five years), in order to measure the impact of financial literacy programs. Key financial literacy initiatives should also be evaluated to assess their impact on those people they are intended to reach. This can help policymakers and funders to decide, on an informed basis, which initiatives should be continued or scaled up and which should be modified or discontinued.

An overview of the main international consumer protection legislation and regulation for the securities sector is presented in Table 3.

Table 3: Overview of Consumer Protection Regulation for the Securities Sector

\begin{tabular}{|c|c|}
\hline Institution & Laws, Regulations, Directives and Guidelines ${ }^{64}$ \\
\hline $\begin{array}{l}\text { IOSCO - International } \\
\text { Organization of } \\
\text { Securities Commissions }\end{array}$ & $\begin{array}{l}\text { Objectives and Principles of Securities Regulation, September } 1998 \text { updated } \\
\text { as of February } 2008 \\
\text { Methodology for Assessing Implementation of the IOSCO Objectives and } \\
\text { Principles of Securities Regulation, October } 2003 \text { updated as of February } \\
2008\end{array}$ \\
\hline EU & $\begin{array}{l}\text { Directive Concerning Processing Personal Data and Protection of Privacy in } \\
\text { the Electronic Communication Sector, 2002/58/EC } \\
\text { Directive on Protection of Consumers in Respect of Distance Contracts, } \\
\text { 1997/7/EEC } \\
\text { Directive on the Distance Marketing of Consumer Financial Services, } \\
\text { 2002/65/EC } \\
\text { Directive on Misleading and Comparative Advertising, 2006/114/EEC } \\
\text { Directive on Markets in Financial Instruments, 2004/39/EC (MiFID) (currently } \\
\text { under revision) }\end{array}$ \\
\hline
\end{tabular}




\begin{tabular}{|c|c|}
\hline Institution & Laws, Regulations, Directives and Guidelines ${ }^{64}$ \\
\hline & $\begin{array}{l}\text { Directive on Investor-Compensation Schemes, 1997/9/EC } \\
\text { Directive on Undertakings in Collective Investments in Transferrable } \\
\text { Securities, 2009/65/EC, recasting 1985/611/EEC (UCITS) }\end{array}$ \\
\hline $\begin{array}{l}\text { European Securities and } \\
\text { Markets Authority } \\
\text { (formerly CESR) }\end{array}$ & $\begin{array}{l}\text { CESR, A Proposal for a European Regime of Investor Protection: The } \\
\text { Harmonization of Conduct of Business Rules, April } 2002\end{array}$ \\
\hline $\begin{array}{l}\text { FINRA - US Financial } \\
\text { Industry Regulatory } \\
\text { Authority }\end{array}$ & $\begin{array}{l}\text { FINRA Manual: FINRA Rules, including NASD Rules and NYSE Rules being } \\
\text { incorporated into the FINRA Manual }\end{array}$ \\
\hline $\begin{array}{l}\text { SEC - US Securities and } \\
\text { Exchange Commission }\end{array}$ & $\begin{array}{l}\text { Securities Act of 1933, and regulations promulgated thereunder } \\
\text { Securities Exchange Act of 1934, and regulations promulgated thereunder } \\
\text { Investment Company Act of 1940, and regulations promulgated thereunder } \\
\text { Investment Advisers Act of 1940, and regulations promulgated thereunder } \\
\text { Securities Investors Protection Act of 1970, as amended, which created } \\
\text { Securities Investors Protection Corporation }\end{array}$ \\
\hline $\begin{array}{l}\text { CFTC - US Commodity } \\
\text { Futures Trading } \\
\text { Commission }\end{array}$ & Commodity Exchange Act \\
\hline $\begin{array}{l}\text { SEBI - Securities Board of } \\
\text { India }\end{array}$ & Master Circular for Mutual Funds 2011 \\
\hline $\begin{array}{l}\text { FIMM - Federation of } \\
\text { Investment Managers } \\
\text { Malaysia }\end{array}$ & $\begin{array}{l}\text { Code of Ethics and Standards of Professional Conduct for the Unit Trust } \\
\text { Industry }\end{array}$ \\
\hline $\begin{array}{l}\text { MAS - Monetary } \\
\text { Authority of Singapore }\end{array}$ & $\begin{array}{l}\text { Guidelines on Standards of Conduct for Financial Advisors and } \\
\text { Representatives }\end{array}$ \\
\hline $\begin{array}{l}\text { SFC - Securities and } \\
\text { Futures Commission of } \\
\text { Hong Kong }\end{array}$ & $\begin{array}{l}\text { Code of Conduct for Persons Licensed by or Registered with the Securities } \\
\text { and Futures Commission } 2010\end{array}$ \\
\hline
\end{tabular}




\section{INSURANCE SECTOR}

While insurance penetration (i.e. premium as a percentage of GDP) is largely dependent on income levels, insurance markets in many emerging and developing countries now have rapidly growing consumer components, driven by the introduction of compulsory motor and health insurance, links with credit provision and the growth of micro-insurance technology. Due to a history of weak regulation and misuse for taxation and capital transfer purposes, or even direct fraud, the insurance sector has also sometimes attracted less than desirable proprietors. These developments inevitably lead to the introduction of specific insurance consumer protection laws and systems (although this step sometimes follows rather than precedes politically sensitive scandals).

There are a number of common undesirable industry practices that can be avoided through strengthening consumer rights. These are unrealistic benefit illustrations, poor disclosure of the real costs of products, misleading advertisements, unfair claims settlement practices and not selling to identified needs. Insurance is an industry where agency incentives can be the main driver of the kind of product and quantity sold. Further, multi-level sales through family and friends and tying and bundling (especially if adhesion principles apply under the law), can limit a consumer's choice and mobility.

Insurance market conduct legislation is most developed in the English speaking world, largely reflecting activist media and an enormous and dynamic case law inventory including a number of high profile cases such as Equitable in the UK. The EU has more recently become engaged in this area with the passage of the Directive on Certain Aspects of Mediation in Civil and Commercial Matters 2008/52/EC and an ongoing dialogue on the broader consumer protection agenda. In developing and emerging markets, consumer protection tends to be secondary to sectoral development and prudential oversight.

The rapid development of microinsurance is forcing a review of the applicability of the emerging mainstream consumer protection regulatory model for low income individuals and families, who often have had little or no prior exposure to the insurance concept. Innovative work has recently been carried out by a range of supervisors, NGOs and institutions including in Peru, South Africa, Brazil and India, through SEEP, CGAP, the Finmark Trust and the Microinsurance Network (the latter working with IAIS). In broad terms, microinsurance regulation contemplates a more relaxed approach to product design, distribution, bundling and branding while requiring higher standards of disclosure (ideally including some prior involvement of the target markets in product design) and strong recourse mechanisms. Table 4 presents a list of key readings related to consumer protection for the insurance sector.

Table 4: Selected Key Readings on Consumer Protection for the Insurance Sector

US National Association of Insurance Commissioners (NAIC), Personal Lines Regulatory Framework, September 2006

Monti, Alberto, "The Law of Insurance Contracts in the People's Republic of China: A Comparative Analysis of Policyholder's Rights", Global Jurists Topics, Volume 1, Edition 3, 2001

UK Parliamentary and Health Services Ombudsman, Equitable Life: A Decade of Regulatory Failure, July 2008

English and Scottish Law Commissions - Insurance Contract Law: A Joint Scoping Paper, 2005

(http://www.scotlawcom.gov.uk/downloads/cp_insurance.pdf) 
Australian Law Reform Commission, Submissions to the Department of Treasury Review of the Insurance Contracts Act 1984 (Cth), 2003 and 2004

Tarr, A A., Insurance Law and the Consumer, Bond University Law Review, Volume 1, 1989

\section{A. Consumer Protection Institutions}

\section{A.1. Consumer Protection Regime}

The law should provide for clear rules on consumer protection in all matters of insurance and there should be adequate institutional arrangements for implementation and enforcement of consumer protection rules.

a. There should be specific provisions in the law, which create an effective regime for the protection of retail consumers of insurance.

b. The rules should prioritize a role for the private sector, including voluntary consumer organizations and self-regulatory organizations.

Good practices demand that insurers offering retail products and services are under supervision for consumer protection purposes because of the essentially opaque nature of insurance contracts (they offer a contingent intangible service delivered sometimes well after the contract is entered into), the enforced use of standard contracts (sometimes subject to adhesion rules), and the complexity of the relevant law (whether civil code or common law based). The 2003 version of the International Association of Insurance Supervisors (IAIS) Core Principles and Methodology (ICP 25 - Consumer Protection) expresses this as follows:

"The supervisory authority sets minimum requirements for insurers and intermediaries in dealing with consumers in its jurisdiction, including foreign insurers selling products on a cross-border basis. The requirements include provision of timely, complete and relevant information to consumers both before a contract is entered into through to the point at which all obligations under a contract have been satisfied."

\section{A.2. Contracts}

There should be a specialized insurance contracts section in the general insurance or contracts law, or ideally a separate Insurance Contracts Act. This should specify the information exchange and disclosure requirements specific to the insurance sector, the basic rights and obligations of the insurer and the retail policyholder and allow for any asymmetries of negotiating power or access to information.

Because of its highly specialized nature and very long history, insurance remains largely subject to a separate specialized body of law. In Civil Code countries, insurance contracts are typically covered by a separate section of the Civil Code, which will often refer to relevant sections elsewhere in that code. The Civil Code may be supplemented by more specific sections in the insurance law dealing with supervisory and prudential matters. Some common law countries have separate insurance contracts laws, and these may supplement a Civil Code in mixed law jurisdictions (e.g. Czech Republic).

Because commercial and industrial insurance usually precedes the development of consumer (retail) insurance markets, the corpus of the insurance law in most developing and many transition markets does not adequately cover B2C situations and such countries often eventually draw on industrial country models. Aside from specifying the minimal contents of an insurance contract (ideally differentiated by the fundamental nature of the coverage - long term, liability, 
property, etc.), helpful B2C contract regulations differentiate between material and non-material non-disclosure, and specify clearly: when the contract goes into force (including cover note situations); when underinsurance justifies the application of average; notification requirements when an insurer wishes to cancel or alter a contract; how contracts will be interpreted in the event of dispute; minimum requirements regarding use of plain words, typeface, etc.; and what clauses may not be included (e.g. warranty clauses, compulsory arbitration on the insurer's terms, etc.). Possible approaches are shown below:

- Eastern European Countries with separate contracts law - Germany, Czech Republic, Austria, Latvia;

- Major other countries with separate insurance contracts law-UK, Australia;

- Major countries with Insurance Contracts section in Insurance Law -China, India, US, Brazil, Russia, Canada;

- Civil Codel Law of Obligations only - Italy, Turkey.

\section{A.3. Code of Conduct for Insurers}

a. There should be a principles-based code of conduct for insurers that is devised in consultation with the insurance industry and with relevant consumer associations, and that is monitored and enforced by a statutory agency or an effective self-regulatory agency.

b. If a principles-based code of conduct exists, insurers should publicize and disseminate it to the general public through appropriate means.

c. The principles-based code should be augmented where appropriate by voluntary codes for insurers on matters specific to insurance products or channels.

d. Every such voluntary code should likewise be publicized and disseminated.

In European legislation, there is no specific demand for establishing codes of conduct in the insurance sector, nor are there provisions that demand the cooperation of the industry and consumer associations. Codes are acknowledged by supervisors and statutory consumer bodies in some other jurisdictions, such as Australia and Malaysia. A selection of codes of conduct for the insurance sector is presented in Table 5.

The exact institutional arrangement depends on legislation (for instance, whether there is provision for the legal institution of a code of conduct). In some European legislation, the existence of codes alone is not sufficient for full compliance (COE Convention).

Table 5: Selected Codes of Conduct for the Insurance Sector

\begin{tabular}{|l|l|l|}
\hline Country & Institution & Code of Conduct \\
\hline Australia & $\begin{array}{l}\text { National Insurance Brokers' } \\
\text { Association } \\
\text { Insurance Council of Australia } \\
\text { Financial Planning Association }\end{array}$ & $\begin{array}{l}\text { General Insurance Brokers' Code of Practice } \\
\text { General Insurance Code of Practice } \\
\text { Financial Planners' Code of Ethics and Rules of } \\
\text { Professional Conduct }\end{array}$ \\
\hline India & Life Insurance Council of India & Code of Best Practice for Indian Life insurers \\
\hline Malaysia & $\begin{array}{l}\text { Life Insurance Association of } \\
\text { Malaysia }\end{array}$ & $\begin{array}{l}\text { Code of Ethics and Conduct (approved by Bank } \\
\text { Nagara) }\end{array}$ \\
\hline Russia & $\begin{array}{l}\text { Russian Association of Motor } \\
\text { Insurers }\end{array}$ & $\begin{array}{l}\text { Various codes, including developing a register of } \\
\text { insurance agents and insurance brokers against whom } \\
\text { complaints have been made; rules of professional } \\
\text { conduct entitled "Improving the level of service in the } \\
\text { MTPL market"; rules covering the review of claims } \\
\text { made by victims and the payment of compensation. }\end{array}$ \\
\hline
\end{tabular}




\begin{tabular}{|l|l|l|}
\hline Country & Institution & Code of Conduct \\
\hline South Africa & $\begin{array}{l}\text { Life Offices' Association of } \\
\text { South Africa }\end{array}$ & $\begin{array}{l}\text { Code of Conduct - 24 chapters covering a range of } \\
\text { products and activities. }\end{array}$ \\
\hline UK & Association of British Insurers & $\begin{array}{l}\text { Various codes and guidance notes, including } \\
\text { Statement of Best Practice for Long-term Care } \\
\text { Insurance, Code of Practice for Endowment Policy } \\
\text { Reviews, Statement of Best Practice for Critical Illness } \\
\text { Insurance, Best Practice Guide on With-Profit Bonds. }\end{array}$ \\
\hline
\end{tabular}

Source: World Bank research and Financial System Assessment Programs (FSAPs)

\section{A.4. Other Institutional Arrangements}

a. Prudential supervision and consumer protection can be placed in separate agencies or lodged in a single institution, but allocation of resources between prudential supervision and consumer protection should be adequate to enable the effective implementation of consumer protection rules.

b. The judicial system should provide credibility to the enforcement of the rules on financial consumer protection.

c. The media and consumer associations should play an active role in promoting consumer protection in the area of insurance.

In countries where insurers fall under the supervision of a body with both market conduct and prudential responsibilities, a balance needs to be found. For instance, in the UK, the FSA was responsible for capital requirements and consumer matters before its recent restructuring. ${ }^{65}$ Similar duties are held by the National Association of Insurance Commissioners' (NAIC) certified state insurance departments in the US. On-site inspectors are required to examine both prudential and market conduct aspects of their charges. Both the FSA and many state supervisors in the US provide web-based support to insurance consumers. ${ }^{66}$ Theoretically it is better to separate these roles (e.g. the Wallis Inquiry - Australia), but institutional reality in many countries means that the prudential supervisor becomes the default recourse for consumers until financial markets have relatively deep penetration into the household sector and formal ombudsmen or equivalents are established (e.g. the UK and Australia ${ }^{67}$ ).

Media and consumer associations often play an active role in promoting financial consumer protection in industrial countries. In all European countries, there are consumer associations that also deal with financial services, and an overview is provided by the European Commission. ${ }^{68}$ If, as under Article 7 of Decision No. 20/2004/EC, specific criteria are fulfilled, an organization might even be supported financially by the EU (this holds for two organizations as of August 2008, the European Consumers' Organization (BEUC) and the European Association for the Co-ordination of Consumer Representation in Standardization (ANEC)).

Further, the EC has created several consultative bodies, such as the Financial Services Consumer Group, a sub-group of the already existing European Consumer Consultative Group. ${ }^{69}$ These are permanent committees that encompass representatives of consumer organizations from each of the Member States. They are particularly asked to ensure that consumer interests are properly taken into account in EU financial services policy. Worldwide addresses of consumer associations can be found on the website of Consumers International. ${ }^{70}$

\section{A.5. Bundling and Tying Clauses}

Whenever an insurer contracts with a merchant or credit grantor (including banks and leasing companies) as a distribution channel for its contracts, no bundling (including enforcing adhesion 
to what is legally a single contract), tying or other exclusionary dealings should take place without the consumer being advised and able to opt out.

Consumer protection can be used to avoid market power abuse by the dominant players. ${ }^{71}$ Vertical restraints between companies of different industries include anti-competitive tying and bundling. Cross-selling that constitutes bundling or tying can have positive demand and supplyside effects, but may also hamper competition and customer mobility. Bundling is the sale of two goods together in a bundle. Firms bundle for several reasons (including economies of scope, price discrimination, demand management or leverage of market power into other market segments). Bundling of faux insurance products has also been used to disguise the real price of associated credit or goods, particularly in Civil Code countries where the doctrine of adhesion applies.

Bundling and tying that limits consumer choice is widespread in markets with weak competition enforcement and should therefore be one of the components to be evaluated when conducting diagnostic reviews of consumer protection. Bundling further has the potential to render price comparisons impossible. Bundling is not per se anti-competitive, but can reduce competition and limit consumer choice, especially if there is a condition to purchase good B together with good A (for instance, a mortgage contract together with unemployment and/or life payment insurance).

Two results of bundling are particularly important for competition policy: (i) the limitation of consumer choice, and (ii) whether other competitors are hindered. For details of the EU approach to bundling and tying practices under competition policy refer to Article 102 of the EC Treaty.

Positive effects on the demand side can exist, when the price of bundled/tied services is lower for consumers than for unbundled goods and if convenience is increased. Supply-side effects may result from reduced costs of providing bundled services.

\section{B. Disclosure and Sales Practices}

\section{B.1. Sales Practices}

a. Insurers should be held responsible for product-related information provided to consumers by their agents (i.e. those intermediaries acting for the insurer).

b. Consumers should be informed whether the intermediary selling them an insurance contract (known as a policy) is acting for them or for the insurer (i.e. in the latter case the intermediary has an agency agreement with the insurer).

c. If the intermediary is a broker (i.e. acting on behalf of the consumer) then the consumer should be advised at the time of initial contact with the intermediary if a commission will be paid to the intermediary by the underwriting insurer. The consumer should have the right to require disclosure of the commission and other costs paid to an intermediary for long-term savings contracts. The consumer should always be advised of the amount of any commission and other expenses paid on any single premium investment contract.

d. An intermediary should be prohibited from identically filling broking and agency roles for a given general class of insurance (i.e. life and disability, health, general insurance, credit insurance).

e. When a bank is the intermediary, the sales process should ensure that the consumer understands at all times that he or she is not purchasing a bank product or a product guaranteed by the bank.

f. Sanctions, including meaningful fines and, in the case of intermediaries, loss of license, should apply for breach of any of the above provisions. 
The main sources of guidance on insurance sales practices in the EU are the consolidated Life Assurance Directive (Chapter 4 and Annex III), the numerous directives covering non-life insurance and motor insurance and the Mediation Directive. Annex III of the Life Assurance Directive in particular requires that life insurance consumers are advised of recourse mechanisms at the time of sale. Some EU members, such as the UK, have disclosure and sales practices that are substantially stronger than those of the Life Assurance Directive and the Mediation Directive, including requiring that full records (sometimes including recordings) of sales transactions are maintained.

Other important directives include: EU Directive on the Distance Marketing of Financial Services, 2002/65/EC; EU Directive on Comparative Advertising, 1997/55/EE; and EU Directive on Unfair Commercial Practices, 2005/29/EC, which sets out misleading practices (Articles 6 and 7) with 23 examples in the Annex, and aggressive practices (Articles 8 and 9) with 8 examples. In Article 10, it is explicitly stated that unfair commercial practices may be controlled through codes of conduct. Further, there can be recourse to out-of-court settlement, but the latter is not equivalent to judicial or administrative recourse.

Outside the EU and its affiliates, the main sources of regulation are, again, the common law industrial countries, and the US and Australia in particular, although there appear to be issues in the US for "force-placed insurance" (i.e. where a lending institution is the policyholder and beneficiary and passes on the cost to its customer). Canada has relied to a greater extent on widely publicized and accessible industry codes of ethics and a long established consumer inquiries center. ${ }^{72}$ China has made consumer protection a core element of its recently updated insurance regulatory model and is pioneering some cutting edge requirements for certain distribution (including certain types of agents, including bank branches) and policy type combinations (including investment linked and participating contracts where benefit illustrations are provided). Innovations include requiring new policyholders to write in their own hand that they understand the terms of the contract they are entering into and requiring insurers to follow up after a short period to verify this.

Bancassurance is becoming a major source of new business growth in many countries, particularly for life insurance and the required rules of operation are still being developed, often on a reactionary basis. The key issue appears to be ensuring that consumers understand that they are not buying a product issued or guaranteed by the bank. Methods of achieving this include requiring that insurance staff, or staff of a bank-owned broker, do the selling (ideally in a different location to deposit and loan counters), requiring higher levels of training for staff selling investment-linked and long-term savings contracts and ensuring that the name of the insurer is clearly disclosed in the sales material and policy document.

\section{B.2. Advertising and Sales Materials}

a. Insurers should ensure their advertising and sales materials and procedures do not mislead customers. Regulatory limits should be placed on investment returns used in life insurance value projections.

b. Insurers should be legally responsible for all statements made in marketing and sales materials they produce related to their products.

c. All marketing and sales materials should be easily readable and understandable by the general public. 
Several directives in Europe hold financial institutions responsible for the content of their public announcements. These are the Directive on the Distance Marketing of Financial Services 2002/65/EC and the Directive on Comparative Advertising 1997/55/EEC.

The treatment of wordings in insurance sales material and contracts is most developed in common law countries, where case law has supported the introduction of such concepts as plain meaning interpretations (consensus ad idem), violation of good faith and fair dealing (mala gestio), and bans on warranty clauses that could otherwise enable insurers to avoid claims. Common law countries have considerable scope to deal with the enormous range of potential transaction types that can arise under property, liability (tort) and credit-related insurance arrangements. Civil code countries tend to rely on specific sections of their Civil Codes or separate Contracts Law (Law of Obligations) and sometimes on strict regulatory/supervisory oversight of transaction and sales material.

\section{B.3. Understanding Customers' Needs}

The sales intermediary or officer should be required to obtain sufficient information about the consumer to ensure an appropriate product is offered. Formal "fact finds" should be specified for long-term savings and investment products and they should be retained and be available for inspection for a reasonable number of years.

The FSA has pioneered these concepts in the insurance sector ${ }^{73}$ It uses the term know your customer, KYC, (in the consumer protection as opposed to the money laundering sense) as follows: "Know your customer (KYC). In the context of advising customers, this is also known as 'factfinding'. It refers to obtaining sufficient information about a customer's personal and financial situation before giving the advice."74

KYC standards in the money laundering sense should be implemented by the national supervisory authorities, whereby financial institutions have different degrees of freedom to design their own customer acceptance policies. The key elements of the policy as it relates to the insurance sector can be found in IAIS ICP 28 - Anti Money Laundering, Combating the Financing of Terrorism, which specifically acknowledges the role of the FATF. In practice, and despite the huge international financial flows the insurance sector generates (part of which is known to involve funds transfer), this sector has been relatively untouched by the AML/CFT community.

\section{B.4. Cooling-off Period}

There should be a reasonable cooling-off period associated with any traditional investment or long-term life savings contract, after the policy information is delivered, to deal with possible high pressure selling and mis-selling.

Cooling-off periods (also known as free look periods) are seen primarily as a consumer protection mechanism, although it has been argued that they are also economically efficient. ${ }^{75}$

The right of withdrawal is enshrined in the Article 6 of the EU Distance Marketing of Consumer Financial Services Directive. According to its provisions, the consumer has the right to withdraw from a contract without penalty and without giving any reasons. The periods vary with product and are longer for insurance contracts and pension products. The period of withdrawal typically begins with the conclusion of the contract and typically is in the range of two weeks (14 calendar days as stated in the aforementioned directive). The EU Life Assurance Directive specifies a cooling off period of between 14 and 30 days after the "contract has been concluded". 
Cooling-off periods are not uncommon for long-term insurance products (i.e. life insurance) in industrial countries and some emerging markets, such as Singapore, and cover a relatively wide range of insurance products in others, such as Australia. ${ }^{76}$ Typically, cooling-off periods for long-term insurance products are longer than cooling-off periods for securities (including investment-linked life contracts) because of the onerous early termination penalties that apply to many traditional life insurance savings contracts. In other countries, such as Japan, certain products, such as variable annuities, have cooling-off periods incorporated into their design.

\section{B.5. Key Facts Statement}

A Key Facts Statement should be attached to all sales and contractual documents, disclosing the key factors of the insurance product or service in large print.

The key facts (and features if intermediary and product are differentiated) requirements are most developed in the UK and reflect the political response to a number of very public scandals, including Equitable. ${ }^{77}$ Key facts statements are also known as initial disclosure documents or $I D D s^{78}$. In other countries (e.g. Australia), standardized B2C insurance contracts are established by law, with the right of derogation provided that this is fully disclosed. Some states in the US specifically ban certain wordings (such as warranty clauses) that would enable an insurer to avoid an otherwise legitimate claim. Some US states also lead the way in applying fair dealing concepts.

\section{B.6. Professional Competence}

a. Sales personnel and intermediaries selling and advising on insurance contracts should have sufficient qualifications, depending on the complexities of the products they sell.

b. Educational requirements for intermediaries selling long-term savings and investment insurance products should be specified, or at least approved, by the regulator or supervisor.

The standard of service delivery depends not only on the product but also on the knowledge and technical know-how of the individual delivering the service. Since the sales person is the direct link between the intermediary or the insurer and the customer, the sales personnel should be properly qualified and knowledgeable about the products that they are selling. Financial products are becoming increasingly complicated. Thus, it is important that consumers fully understand these complex products before buying them.

\section{B.7. Regulatory Status Disclosure}

a. In all of its advertising, whether by print, television, radio or otherwise, an insurer should disclose: (i) that it is regulated, and (ii) the name and address of the regulator.

b. All insurance intermediaries should be licensed and proof of licensing should be readily available to the general public, including through the internet.

This is in line with responsible and fair commercial practices. The status disclosure is important to signal the trustworthiness of the company and indicate the authority that regulates it.

\section{B.8. Disclosure of Financial Situation}

a. The regulator or supervisor should publish annual public reports on the development, health, strength and penetration of the insurance sector either as a special report or as part of the disclosure and accountability requirements under the law governing it.

b. Insurers should be required to disclose their financial information to enable the general public to form an opinion with regards to the financial viability of the institution. 
c. If credible claims paying ability ratings are not available, the regulator or supervisor should periodically publish sufficient information on each insurer for an informed commentator or intermediary to form a view of the insurer's relative financial strength.

IAIS ICP 26 (Information, Disclosure and Transparency towards the Market) covers disclosure and is summarized as follows:

"The supervisory authority requires insurers to disclose relevant information on a timely basis in order to give stakeholders a clear view of their business activities and financial position and to facilitate the understanding of the risks to which they are exposed."

Virtually every country requires insurers to publish their annual financial statements (or more often summaries thereof) in the print media at least annually. In most industrial and emerging markets, the leading insurers already have websites that include their product offerings and periodic financial statements, including annual reports. Unfortunately, accounting and actuarial standards are still not at international levels in the majority of emerging and developing countries. In industrial countries, the relevant IFRS remains mired in controversy, particularly in accounting for the fair value of liabilities. Regardless of context, a high degree of sophistication is required to interpret the financial information provided. As a fallback, some countries (e.g. Pakistan) require that claims paying ability be rated for all insurers, although the relevant rules do not always specify that international rating agencies should be employed.

Detailed technical data are available in some industrial countries, most notably in the US, although in other countries (e.g. Australia) certain information such as claims run-off triangles ${ }^{79}$ has been withdrawn under industry pressure.

\section{Customer Account Handling and Maintenance}

\section{C.1. Customer Account Handling}

a. Customers should receive periodic statements of the value of their policy in the case of insurance savings and investment contracts. For traditional savings contracts, this should be provided at least yearly, however more frequent statements should be produced for investment-linked contracts.

b. Customers should have a means to dispute the accuracy of the transactions recorded in the statement within a stipulated period.

c. Insurers should be required to disclose the cash value of a traditional savings or investment contract upon demand and within a reasonable time. In addition, a table showing projected cash values should be provided at the time of delivery of the initial contract and at the time of any subsequent adjustments.

d. Customers should be provided with renewal notices a reasonable number of days before the renewal date for non-life policies. If an insurer does not wish to renew a contract it should also provide a reasonable notice period.

e. Claims should not be deniable or adjustable if non-disclosure is discovered at the time of the claim but is immaterial to the proximate cause of the claim. In such cases, the claim may be adjusted for any premium shortfall or inability to recover reinsurance.

f. Insurers should have the right to cancel a policy at any time (other than after a claim has occurred - see above) if material non-disclosure can be established.

Insurance law rarely deals with customer account handling in any detail - partly reflecting the huge variation in insurance arrangements that are possible. The EU Life Assurance Directive 
does require that policyholders are advised of bonus developments, but this does not appear to mean that individual policyholders are regularly advised of the cash value of their contracts. The heavy selling costs associated with traditional life insurance products often means that a contract has no value for some years and there are strong incentives for the life insurance sector to resist cash value disclosure for the first 5 or more years a contract is in force. As markets develop, insurers tend to unbundle the pure risk, and savings/investment components of long-term contracts and disclosure standards often improve.

\section{Privacy and Data Protection}

\section{D.1. Confidentiality and Security of Customers' Information}

Customers have a right to expect that their financial transactions are kept confidential. Insurers should protect the confidentiality and security of personal data, against any anticipated threats, or hazards to the security or integrity of such information, and against unauthorized access.

The confidentiality of personally identifiable information, that is any information about an identified or identifiable individual, is protected under several international statutes, such as the OECD Guidelines governing the Protection of Privacy and Transborder Flows of Personal Data (Article 2 Scope of Guidelines) and the UN Guidelines for the regulation of computerized personal data files, adopted by the General Assembly on 14 December 1990 (Section A Principles concerning the minimum guarantees that should be provided in national legislations).

Further, important statutes are the EU Directive on the Protection of Individuals with regard to the Processing of Personal Data 1995/46/EC (Chapter 1, Articles 1-3), the COE Convention for the Protection of Individuals with regard to Automatic Processing of Personal Data (ETS No. 108, 28 January 1981, Chapter 1 General Provisions) and the APEC Privacy Framework (Part ii, Scope).

Technical security is also demanded under the above guidelines and directives. A more detailed guideline on such security has been provided by the OECD Guidelines for the Security of Information Systems and Networks: Towards a Culture of Security.

In the US, the FTC has established guidelines in the form of Standards for Safeguarding Customer Information, which obligates financial institutions to hold customer information secure and confidential. ${ }^{80}$

The use of medical and genetic (biometric) information for the acceptancel decline and rating of life-related risks is now a major area of debate, but is not within the scope of the Good Practices.

\section{E. Dispute Resolution Mechanisms}

\section{E.1. Internal Dispute Settlement}

a. Insurers should provide an internal avenue for claim and dispute resolution to policyholders.

b. Insurers should designate employees to handle retail policyholder complaints.

c. Insurers should inform their customers of the internal procedures on dispute resolution.

d. The regulator or supervisor should investigate whether insurers comply with their internal procedures regarding consumer protection.

Few customers have the knowledge to realize that their rights have been infringed and, even if they become aware of this, they typically have few avenues to pursue their claims. Thus, insurers 
should be mandated to have an internal dispute resolution or complaint handling mechanism, which provides a first level of dispute resolution. Unless there are voluntary consumer associations that have the resources and skills to assist customers with their complaints or legal actions against insurers, consumers do not have many ways in which to seek redress.

Insurers need to have written policies in place for dispute settlement. A written policy should hold the insurer liable for the policy publicly announced by the insurer. This policy should offer contact points for the consumer that are accessible during business hours without undue waiting time (ideally through a dedicated call center), state in plain language the main steps of customer dispute resolution, provide firm and reasonable timelines, guarantee fairness in handling a customer dispute, state the coordination with any ombudsman and/or supervisory authority, and explain in plain language the consumer's rights in the process. Consumer dispute settlement should not lead to unreasonable costs in terms of time and money for the consumer.

The EU Life Assurance Directive requires that policyholders are advised of their right of recourse; however specific provisions of this type are uncommon in insurance law. Consumer protection law sometimes does provide for notification of rights, although insurance transactions may be excluded in certain circumstances (e.g. the latest version of the Croatian Consumer Protection Act, Official Gazette 125/2007).

\section{E.2. Formal Dispute Settlement Mechanisms}

a. A system should be in place that allows consumers to seek affordable and efficient third-party recourse, which could be an ombudsman or tribunal, in the event the complaint with the insurer cannot be resolved to the consumer's satisfaction in accordance with internal procedures.

b. The role of an ombudsman or equivalent institution vis-à-vis consumer disputes should be made known to the public.

c. The ombudsman or equivalent institution should be impartial and act independently from the appointing authority and the industry.

d. The decisions of the ombudsman or equivalent institution should be binding upon the insurers. The mechanisms to ensure the enforcement of these decisions should be established and publicized.

A specialized insurance Ombudsman or insurance claims and inquiries service (sometimes as part of an omnibus Ombudsman service as in the UK) is increasingly regarded as a fundamental requirement for sound consumer protection. Twenty eight countries are currently members of the International Network of Financial Ombudsman Schemes ${ }^{81}$. However, it can be difficult for an Ombudsman to mediate and ameliorate the problems faced by policyholders effectively without clear codes of insurance practice and standardized contracts. One of the most advanced systems is to be found in Australia, where an SRO-based insurance inquiries and complaints resolution system has evolved into a fully-fledged financial system ombudsman. ${ }^{82}$ Some countries also use small claims courts to provide an affordable means for the average customer to bring action against sellers, service providers and corporations. However such courts often lack sufficient transparency or specialized expertise in insurance issues.

\section{F. Guarantee Schemes and Insolvency}

\section{F.1. Guarantee Schemes and Insolvency}

a. With the exception of schemes covering mandatory insurance (and possibly long-term insurance), insolvency guarantee schemes are not to be encouraged for insurance because of 
the opaque nature of the industry, the resulting fiscal risk to taxpayers where supervision and governance are not adequate, and the scope for moral hazard. Strong governance and prudential supervision are better alternatives.

b. Nominal defendant arrangements should be in place for mandatory insurances such as motor third party liability insurance to cover situations where there is no insured guilty party.

c. Assets covering life insurance mathematical reserves and investment contract policy liabilities should be segregated or at the very least earmarked, and long-term policyholders should have preferential access to such assets in the event of a winding-up.

Non-life insurance is typically subjected to normal commercial wind-up rules in the event of insurer insolvency, and the subsequent claims settlement process is usually handled by specialist run-off companies. Policyholders normally arrange new coverage with the remaining solvent insurers in the market concerned. However, most countries do have claims guarantee arrangements for mandatory consumer classes, such as motor third party insurance. These cover claims that cannot be settled due to insurer bankruptcy or because the guilty driver/ vehicle cannot be identified (i.e. the guarantee fund acts as "nominal defendant").

Life insurance is also often deemed to require supplementary arrangements because it can represent a significant asset for the individual or household and may also serve as loan collateral. In this case the usual protection is primarily afforded through separation of life and non-life insurers and strong prudential oversight. However, composites (insurers writing both life and non-life policies) have been grandfathered in numerous countries and special additional arrangements are required in this situation. This may range from the relatively weak EU Directive on Reorganization and Winding-up of Insurance Undertakings, which requires that the assets covering defined life insurance liabilities are earmarked, to the requirement that completely separate statutory funds are maintained, as in South Africa, Pakistan and Australia. In addition, life policyholders normally rank very high in terms of creditor priority. Most countries also either specify investment limits for the assets covering life insurance mathematical reserves or, where risk-based supervision already operates, require that capital allocated reflects the risk characteristics of the asset portfolio.

\section{G. Consumer Empowerment \& Financial Literacy}

\section{G.1. Broadly based Financial Literacy Program}

a. A broadly based program of financial education and information should be developed to increase the financial literacy of the population.

b. A range of organizations-including government, state agencies and non-governmental organizations-should be involved in developing and implementing the financial literacy program.

c. The government should appoint an institution such as the central bank or a financial regulator to lead and coordinate the development and implementation of the national financial literacy program.

Financial education, information and guidance can help consumers to budget and manage their income, to save, invest and protect themselves against risks, and to avoid becoming victims of financial fraud and scams. As financial products and services become more sophisticated and households assume greater responsibility for their financial affairs, it becomes increasingly important for individuals to manage their money well, not only to help secure their own and their family's financial well-being, but also to facilitate the smooth functioning of financial markets and the economy. 
Many organizations in both the public and private sector have an interest in improving people's financial literacy. They should work together on this issue, so that there is a range of initiatives which, over time, will help to drive up people's ability to manage their personal finances.

\section{G.2. Unbiased Information for Consumers}

a. Consumers, especially the most vulnerable, should have access to sufficient resources to enable them to understand financial products and services available to them.

b. Financial regulators should provide, via the internet and printed publications, independent information on the key features, benefits and risks - and where practicable the costs-of the main types of financial products and services.

c. Non-governmental organizations should be encouraged to provide consumer awareness programs to the public regarding financial products and services.

Financial regulators should take an active role in consumer education as part of its role to protect consumers. Consumers are more likely to have the confidence to purchase insurance products which are suitable for them if they have access to information which is reliable and objective.

\section{G.3. Measuring the Impact of Financial Literacy Initiatives}

a. Policymakers, industry and advocates should understand the financial literacy of various market segments, particularly those most vulnerable to abuse.

b. The financial literacy of consumers should be measured through a broad-based household survey that is repeated from time to time.

c. The effectiveness of key financial literacy initiatives should be evaluated.

The financial literacy of a sample of the population should be measured by means of a nationwide household survey that gets repeated from time to time (every four to five years), in order to measure the impact of financial literacy programs. Key financial literacy initiatives should also be evaluated to assess their impact on those people they are intended to reach. This can help policymakers and funders to decide, on an informed basis, which initiatives should be continued or scaled up and which should be modified or discontinued.

Table 6 gives key insurance laws and regulations worldwide.

Table 6: Overview of Consumer Protection Regulation for the Insurance Sector

\begin{tabular}{|l|l|}
\hline Institution & Laws, Regulations, Directives and Guidelines \\
\hline UN-United Nations & $\begin{array}{l}\text { UN Guidelines for the Regulation of Computerized Personal Data Files, } \\
\text { adopted by the General Assembly Resolution 45/95 of 14 December 1990 }\end{array}$ \\
\hline $\begin{array}{l}\text { IAIS-International } \\
\text { Association of }\end{array}$ & $\begin{array}{l}\text { Insurance Core Principles and Methodology, October 2003 } \\
\text { Guidance Paper No. 4 on Public Disclosure by Insurers, January } 2002\end{array}$ \\
\hline OECD & $\begin{array}{l}\text { Good Practices for Enhanced Risk Awareness and Education in Insurance } \\
\text { Issues, 2008 } \\
\text { Guidelines for the Security of Information Systems and Networks: Towards a } \\
\text { Culture of Security, 2002 } \\
\text { Guidelines for Good Practices for Insurance Claims Management, November } \\
2004\end{array}$ \\
\hline APEC & APEC Privacy Framework, 2005 \\
\hline EU & Directive concerning Life Assurance, 2002/83/EC \\
\hline
\end{tabular}




\begin{tabular}{|c|c|}
\hline Institution & Laws, Regulations, Directives and Guidelines \\
\hline & $\begin{array}{l}\text { Directives on Non Life Insurance and Motor Insurance } \\
\text { Directive on Insurance Agents and Brokers, 1977/92/EC } \\
\text { Directive on Insurance Mediation, 2002/92/EC } \\
\text { Directive on Reorganization and Winding-up of Insurance Undertakings, } \\
\text { 2001/17/EC } \\
\text { Directive Concerning Processing Personal Data and Protection of Privacy in } \\
\text { the Electronic Communication Sector, 2002/58/EC } \\
\text { Directive on Protection of Consumers in Respect of Distance Contracts, } \\
\text { 1997/7/EEC } \\
\text { Directive on the Distance Marketing of Consumer Financial Services, } \\
\text { 2002/65/EC } \\
\text { Directive on Misleading and Comparative Advertising, 2006/114/EEC } \\
\text { Directive on the Protection of Individuals with regard to the Processing of } \\
\text { Personal Data and on the Free Movement of such data, 1995/46/EC } \\
\text { Recommendation on the Principles applicable to the Bodies responsible for } \\
\text { Out-of-court Settlement of Consumer Disputes, } 98 / 257 / E C \\
\text { Recommendation on the Principles for Out-of-court Bodies involved in the } \\
\text { Consensual Resolution of Consumer Disputes, 2001/310/EC } \\
\text { Green Paper on Retail Financial Services in the EU: Com (2007) 226 Final } \\
\text { Policy statement: Nature and consequences of pyramid activities in life and } \\
\text { accident insurance: Commission on Financial Services and Insurance, } 30 \text { May } \\
\text { 1997 } \\
\text { The Project Group - Restatement of European Insurance Contract Law } \\
\text { submission to the European Commission - Draft Common Frame of } \\
\text { Reference (CFR): "Insurance Contract": http://www.restatement.info/ }\end{array}$ \\
\hline COE - Council of Europe & $\begin{array}{l}\text { Convention for the Protection of Individuals with regard to Automatic } \\
\text { Processing of Personal Data (ETS No. } 108 \text { of } 28 \text { January 1981, entered into } \\
\text { force on } 01 \text { October 1985) and Explanatory Report }\end{array}$ \\
\hline $\begin{array}{l}\text { Other leading } \\
\text { jurisdictions }\end{array}$ & $\begin{array}{l}\text { US National Association of Insurance Commissioners (NAIC) - Market } \\
\text { Conduct Surveillance Model Law, } 2004 \\
\text { FTC - Standards for Safeguarding Customer Information, } 2002 \\
\text { Australia - Insurance Contracts Act, } 1984 \text { as amended } \\
\text { Alberta, Canada - Fair Practices Regulation under Insurance Act, 128/ } 2001 \\
\text { FDIC (US) Laws and Regulations - Part 343-consumer protection in sales of } \\
\text { insurance } \\
\text { Latvia - Insurance Contracts Law, September } 1998 \text { as amended } \\
\text { Czech Republic - The Insurance Contract Act, December } 2003 \\
\text { Czech Republic - Act on Insurance Intermediaries and Loss Adjusters, } \\
\text { December } 2003\end{array}$ \\
\hline
\end{tabular}




\section{Non-BAnk Credit Institutions}

Consumer finance provided by non-bank credit institutions is an ever more important segment of the credit market. Countries follow different approaches in the regulation of non-bank credit institutions. Some fall under the supervision of the central bank or banking supervisory agency. Others are under the general consumer protection agency or the economic development ministry or local government authorities. Non-bank credit institutions conduct consumer lending in most cases without taking cash deposits from the public. Thus, they fall outside the scope of prudential regulation. The range of legal forms of the non-bank credit institutions varies, but typically they encompass microfinance institutions, consumer finance companies (including credit card companies), leasing firms,${ }^{83}$ mortgage lenders, pawn shops and credit cooperatives. Depending on the country, there may be difficulties in identifying non-bank credit institutions. Government authorities should establish mechanisms that ensure the identification of all non-bank credit institutions.

A number of undesirable industry practices by non-bank credit institutions can be avoided by strengthening consumer rights. These practices include predatory lending, discriminatory pricing, poor disclosure of costs of products and misleading advertisement. Further, tying and bundling practices can limit a consumer's choice and mobility.

Legislation regarding non-bank credit institutions is especially developed in Europe and in the US. Thus, the examples and background for the Good Practices are primarily drawn from European and US legislation. In addition, they also rely on guidelines and guidance from international institutions such as the BIS (see Table 8).

\section{A. Consumer Protection Institutions}

\section{A.1. Consumer Protection Regime}

The law should provide clear consumer protection rules in the area of non-bank credit institutions, and there should be adequate institutional arrangements to ensure the thorough, objective, timely and fair implementation and enforcement of all such rules, as well as of sanctions that effectively deter violations of these rules.

a. There should be specific statutory provisions, which create an effective regime for the protection of consumers of non-bank credit institutions.

b. There should be a government authority responsible for implementing, overseeing and enforcing consumer protection in the area of non-bank credit institutions.

c. The supervisory authority for non-bank credit institutions should have a register which lists the names of non-bank credit institutions.

d. There should be coordination and cooperation among the various institutions mandated to implement, oversee and enforce consumer protection and financial sector regulation and supervision.

e. The law should provide for, or at least not prohibit, a role for the private sector, including voluntary consumer associations and self-regulatory organizations, in respect of consumer protection in the area of non-bank credit institutions.

It differs from country to country whether non-bank credit institutions are under the supervision of a financial supervisory agency. In some countries, lending to consumers is considered a banking activity and a license from the banking regulator is needed to conduct such activities. In 
other countries, non-bank credit institutions are only required to be registered, and are lightly supervised by a consumer protection agency or a department within a ministry.

Good practices demand that non-bank credit institutions be supervised for consumer protection purposes in order to avoid eroding existing rules in banking by taking advantage of weaker or non-existent rules regarding the provision of financial products and services by reason simply of being established under a different institutional category.

Non-bank credit institutions in Europe are not exempt from consumer protection provisions, which exist especially in the EU Directive 2008/48/EC on Credit Agreements for Consumers, repealing Directive 87/102/EEC. However, the enforcement of the law differs from country to country and depends on national institutional arrangements.

In general, the industry is free to create its own codes of conduct, which are not specifically demanded by the above quoted directives.

\section{A.2. Code of Conduct for Non-Bank Credit Institutions}

a. There should be a principles-based code of conduct for non-bank credit institutions that is devised in consultation with the non-bank credit industry and with relevant consumer associations, and that is monitored by a statutory agency or an effective self-regulatory agency.

b. If a principles-based code of conduct exists, it should be publicized and disseminated to the general public.

c. The principles-based code should be augmented by voluntary codes on matters specific to the industry (credit unions, credit cooperatives, other non-bank credit institutions).

d. Every such voluntary code should likewise be publicized and disseminated.

In European legislation, there is neither a specific requirement to establish codes of conduct on lending, nor are there provisions that demand the cooperation of the industry and consumer associations. However, there are principles-based codes, such as from the Finance \& Leasing Association in the UK. This code, which applies to a number of products (e.g. loans, store cards, credit cards, personal loans), covers lending and information and marketing practices. The institutional arrangements depend on legislation (for instance, whether it provides for the legal institution in terms of a code of conduct). However, the COE Convention on the protection of personal data notes that the existence of codes alone is not sufficient for full compliance. Table 7 lists selected lending codes of conduct in Europe.

Table 7: Selected Codes of Conduct for Lending in Europe

\begin{tabular}{|l|l|}
\hline Country & Original Title \\
\hline Belgium & $\begin{array}{l}\text { Code of Conduct } \\
\text { Comment changer de banque facilement }\end{array}$ \\
\hline Bulgaria & Ethical Code \\
\hline Cyprus & $\begin{array}{l}\text { Code of Banking Conduct } \\
\text { Code for Conduct between Banks and Small and Medium-sized Enterprises }\end{array}$ \\
\hline Czech Republic & $\begin{array}{l}\text { Code of Conduct on Relations Between Banks and Clients } \\
\text { Ethical Code of the Czech Banking Association }\end{array}$ \\
\hline Finland & Good Banking Practice \\
\hline Hungary & Code of Ethics \\
\hline Ireland & Business Account Switching Code
\end{tabular}




\begin{tabular}{|l|l|}
\hline Country & Original Title \\
\hline & $\begin{array}{l}\text { Code of Practice on Switching Accounts } \\
\text { Code of Practice on Mortgage Arrears }\end{array}$ \\
\hline Luxembourg & Consumer Protection Code \\
\hline UKetherlands & $\begin{array}{l}\text { Code of Conduct for the Processing of Personal Data by Financial Institutions } \\
\text { Code of Conduct on Mortgage Credit } \\
\text { Switch Support Service }\end{array}$ \\
\hline Europe & $\begin{array}{l}\text { Lending Code } \\
\text { Code of Conduct for the Advertising of Interest Bearing Accounts } \\
\text { Code of Conduct of the Finance \& Leasing Association }\end{array}$ \\
\hline
\end{tabular}

Source: European Credit Research Institute

\section{A.3. Other Institutional Arrangements}

a. Whether non-bank credit institutions are supervised by a financial supervisory agency, the allocation of resources between financial supervision and consumer protection should be adequate to enable their effective implementation.

b. The judicial system should ensure that the ultimate resolution of any dispute regarding a consumer protection matter with a non-bank credit institution is affordable, timely and professionally delivered.

c. The supervisory authority for non-bank credit institutions should encourage media and consumer associations to play an active role in promoting consumer protection regarding non-bank credit institutions.

Media and consumer associations play a very active role in promoting financial consumer protection in many countries, including with regards to non-bank credit and microfinance institutions. In all European countries, there are consumer associations that deal with financial services. ${ }^{84}$ Organizations might even be supported financially by the EU if specific criteria are fulfilled (e.g. Article 7 of the EU Decision No. 20/2004/EC establishing a General Framework for Financing Community Actions in support of Consumer Policy for the Years 2004 to 2007 and Article 5 of the EU Decision No. 1926/2006/EC establishing a Programme of Community Action in the field of Consumer Policy 2007-2013).

Furthermore, the EC has created several consultative bodies, such as the Financial Services Consumer Group, a sub-group of the already existing European Consumer Consultative Group. ${ }^{85}$ Permanent committees encompass representatives of consumer organizations from each of the EU Member States. They are specifically asked to ensure that consumer interests are properly taken into account in the EU financial services policy. Another group is the European Consumer Debt Network, a network of debt counselors in different countries. Addresses of worldwide consumer associations can be found on the website of Consumers International. ${ }^{86}$

\section{A.4. Licensing of Non-Bank Credit Institutions}

All financial institutions that extend any type of credit to households should be licensed by a financial supervisory authority.

The authority should have the power to set criteria and reject applications for establishments that do not meet the standards set. The authority should verify that the significant owners (and those 
who control ownership), as well as the senior managers of the financial institutions, satisfy minimal fit and proper requirements, including no history of bankruptcy or criminal conviction.

\section{B. Disclosure and Sales Practices}

\section{B.1. Information on Customers}

a. When making a recommendation to a consumer, a non-bank credit institution should gather, file and record sufficient information from the consumer to enable the institution to render an appropriate product or service to that consumer.

b. The extent of information the non-bank credit institution gathers regarding a consumer should:

i. be commensurate with the nature and complexity of the product or service either being proposed to or sought by the consumer; and

ii. enable the institution to provide a professional service to the consumer in accordance with that consumer's capacity.

This good practice is a basic requirement for the delivery of services as well as to ensure compliance with the FATF Recommendations on Customer Due Diligence and Record-keeping. According to Recommendation 5, financial institutions should undertake customer due diligence measures, including identifying and verifying the identity of their customers and of the beneficial owners, as well as obtaining information on the purpose and intended nature of the business relationship. ${ }^{87}$ Typically, the degree of due diligence depends on the risks associated with the transaction and the particular client. Although non-bank financial institutions that are not deposit-taking cannot be used for money laundering, identification of customers is in their interest due to high fraud risk.

Although accurate and reliable customer identification is important to fight against frauds, it can present a special challenge for low-income countries where national ID cards have not yet been issued. Some credit institutions, for example in India and Malawi, use biometric measures to identify customers. In addition, transactions conducted through mobile telephones create their own issues regarding reliable customer identification. In some developing countries, regulators have started to experiment with a decrease in KYC requirements for small transaction accounts (e.g. in India, Maldives and South Africa, among others). However, there are no international guidelines about how this is best conducted.

\section{B.2. Affordability}

a. When a non-bank credit institution makes a recommendation regarding a product or service to a consumer, the product or service it offers to that consumer should be in line with the need of the consumer.

b. Sufficient information on the product or service should be provided to the consumer to enable him or her to select the most suitable and affordable product or service.

c. When a non-bank credit institution offers a new credit product or service that significantly increases the amount of debt assumed by the consumer, the consumer's credit worthiness should be properly assessed.

Affordability looks at whether a consumer can afford additional debt obligations once the monthly income net of financial and living expenses (including rent or mortgage payments) is considered. Households might have different tolerances with respect to the share of current income they want to devote to debt-servicing. Creditworthiness involves estimating default or delinquency risks and is a component of responsible lending. The EU Directive on Credit 
Agreements for Consumers (Article 8) requires a creditor to assess the consumer's creditworthiness based on information obtained from the consumer as well as from a relevant database, such as a credit bureau. The provisions of this Directive hold for all lenders, including non-bank credit institutions. Products covered include all credit contracts between $€ 200$ $€ 75,000 .{ }^{88}$ The provisions only apply to contracts in which the consumer has to pay interest. Deferred payment cards and mortgage credit are not included.

In the US, a number of consumer protection provisions have been introduced as amendments to Regulation AA on Unfair or Deceptive Acts or Practices, the Truth in Lending Act (TILA) and the Truth in Savings Act. For example, the Federal Reserve Board has approved an amendment to TILA that aims to ensure responsible lending in mortgage markets. One of the key provisions is a lender's responsibility to assess the repayment ability of a borrower by checking income and other assets, excluding the value of the property being mortgaged.

Affordability may also be related to concerns over possible over-indebtedness. In some countries, non-bank credit and microfinance institutions are not required to ask borrowers about other outstanding debts-or such debts may not be registered in the credit reporting system. The result may be consumers who become over-indebted, relying on one loan to pay off another. In Peru, the regulator has issued Regulation 6941-2008 (Rules for administration of over-indebtedness risk of retail debtors) to ensure that consumers do not use easy access to credit cards or other forms of credit to become over-indebted. In South Africa, over-indebtedness, reckless lending and debt counseling are regulated in Chapter 3 Part D of the National Credit Act Regulations of May 31, 2006. This legislation regulates what information should be sent to the National Credit Register as well as what information should be submitted to debt counselors. Under Part D, 24 (7), a consumer is considered to be over-indebted if his or her total monthly debt payments exceed the balance derived by deducting minimum living expenses from net income.

\section{B.3. Cooling-off Period}

a. For financial products or services with a long-term savings component, or those subject to high-pressure sales contracts, (unless explicitly waived by the consumer in writing), a nonbank credit institution should provide the consumer a cooling-off period of a reasonable number of days (at least 3-5 business days) immediately following the signing of an agreement between the institution and the consumer.

b. On his or her written notice to the non-bank credit institution during the cooling- off period, the consumer should be permitted to cancel or treat the agreement as null and void without penalty to the consumer of any kind.

In many cases, borrowers rush into financial arrangements with non-bank credit institutions that provide seemingly attractive terms or returns without the benefit of shopping around, reading thoroughly over the financial contract or asking for advice. This is especially serious in countries where the terms of services and products are not readily available or cannot be compared. Thus, the cooling-off period provides relief similar to a "no-questions-asked" return policy for goods. However, for products and services that involve market risk, a consumer who cancels his or her contract during the cooling-off period should be required to compensate the non-bank credit institution for any losses. For a description of cooling-off periods in several EU Member States, see the EC's Discussion Paper for the amendment of the Directive 87/102/EEC concerning consumer credit.

The right of withdrawal is enshrined in Article 6 of the EU Distance Marketing of Financial Services Directive, which states that the consumer has the right to withdraw from a contract without penalty and without giving any reasons. The period of withdrawal typically begins with 
the conclusion of the contract and is usually in the range of two weeks (14 calendar days as stated in the EU Directive).The length of the cooling-off period should depend on the type of financial product being sold. The period should be longer for products which involve long-term savings and may be subject to distribution systems such as "multi-level selling", which are often associated with high pressure sales tactics.

\section{B.4. Bundling and Tying Clauses}

a. As much as possible, non-bank credit institutions should avoid the use of tying clauses in contracts that restrict the choice of consumers.

b. In particular, whenever a borrower is required by a non-bank credit institution to purchase any product, including an insurance policy, as a pre-condition for receiving a loan, the borrower should be free to choose the provider of the product and this information should be made known to the borrower.

c. Also, whenever a non-bank credit institution contracts with a merchant as a distribution channel for its credit contracts, no exclusionary dealings should be permitted.

Cross-selling that constitutes bundling or tying can have positive demand and supply-side effects. However, it may also hamper competition and customer mobility. Bundling occurs when two or more products are sold together, although each product can also be purchased separately in the market. Firms bundle for several reasons, such as economies of scope, price discrimination, demand management or leverage of market power into other market segments. Positive effects on demand exist when the price of bundled products or services is lower for consumers than for unbundled goods and if convenience is increased. Bundling is not per se anti-competitive-it only becomes anti-competitive if market power is leveraged to the detriment of competitors.

Tying occurs when two or more products are sold together in a package and at least one of these products is not sold separately. Tying can be used by financial institutions to reduce competition and limit consumer choice, especially if there is a condition to purchase good B together with good A (for instance, a mortgage contract together with payment insurance). Furthermore tying can increase pricing by obscuring costs for consumers and rendering price comparisons impossible. However, consumer protection can be used to avoid market power abuse by dominant players. $^{89}$

Tying and bundling practices that limit consumer choice is often widespread in markets with weak competition enforcement and should therefore be evaluated when conducting diagnostic reviews of consumer protection. Two criteria are important for consideration: (i) the limitation of consumer choice and (ii) whether other competitors are hindered. In the EU, bundling and tying practices may constitute an exclusionary abuse of dominance under Article 102 of the EC Treaty.

\section{B.5. Key Facts Statement}

a. Non-bank credit institutions should have a Key Facts Statement for each type of account, loan or other products or services.

b. The Key Facts Statement should be written in plain language, summarizing in a page or two the key terms and conditions of the specific financial product or service, and allowing consumers the possibility of easily comparing products offered by different institutions.

A Key Facts Statement provides consumers with simple and standard disclosure of key contractual information of a financial product or service, contributing to the consumers' better understanding of the product or service. Key Facts Statements also allow consumers to compare offers provided by different financial institutions before they purchase a financial product or 
service and provide a useful summary for later reference during the life of the financial product or service. For credit products, Key Facts Statements constitute an efficient way to inform consumers about their basic rights, the credit reporting systems and the existing possibilities for disputing information. This is of special importance in countries with new financial consumers who are inexperienced.

There are several examples of Key Facts Statements worldwide, such as the SECCI form for consumer credits in the European Union, the ESIS format for pre-contractual information on home loans developed by the European Associations of Consumers and the European Credit Sector Associations, the "Schumer Box" for credit cards in the US, the "Hoja Resumen" for consumer credits in Peru

Of special concern in some countries is the need to provide basic information to consumers in a language that is widely used by local populations. It may also be helpful to test consumer understanding of mandatory disclosure statements. For further information, see annotation of good practice B.5 in the banking section.

\section{B.6. Advertising and Sales Materials}

a. Non-bank credit institutions should ensure that their advertising and sales materials and procedures do not mislead customers.

b. All advertising and sales materials should be easily readable and understandable by the general public.

c. Non-bank credit institutions should be legally responsible for all statements made in advertising and sales materials (i.e. be subject to the penalties under the law for making any false or misleading statements).

For disclosure and sales practices, one of the main policy issues relates to misleading and comparative advertisement. Several directives in Europe hold financial institutions responsible for the content of their public announcements. These include the EU Directive on the Distance Marketing of Consumer Financial Services 2002/65/EC, the EU Directive on Misleading and Comparative Advertising 2006/114/EEC and the Unfair Commercial Practices Directive 2005/29/EC.

In some countries non-bank credit institutions use agents to market and distribute their products, such as credit or pre-paid cards. These solicitations take place outside the institutions' premises -including at supermarkets, drugstores and fairs. Thus, ensuring that non-bank credit institutions are liable for the acts of their agents is critical.

\section{B.7. General Practices}

Specific rules on disclosure and sales practices should be included in the non-bank credit institutions' code of conduct and monitored by the relevant supervisory authority.

The EU Directive on Credit Agreements for Consumers 2008/48/EC mandates what information has to be included in contracts with consumers (Article 9 on pre-contractual information). In the US, provisions can be found in the TILA of 1968 and the Federal Trade Commission Act (Section 5). The EU Unfair Commercial Practices Directive defines misleading practices (Articles 6-7) and aggressive practices (Articles 8-9), and presents several examples that illustrate such practices (Annex). This Directive also explicitly states that unfair commercial practices may be controlled through codes of conduct (Article 10). Once a code of conduct exists, non-bank credit institutions should bind themselves to fair disclosure and sales practices. 


\section{B.8. Disclosure of Financial Situation}

a. The relevant supervisory authority should publish annual public reports on the development, health, strength and penetration of the non-bank credit institutions, either as a special report or as part of the disclosure and accountability requirements under the law that governs these.

b. Non-bank credit institutions should be required to disclose their financial information to enable the general public to form an opinion regarding the financial viability of the institution.

In several countries, non-bank credit institutions are required to report their financial situation periodically. However, a common problem is that the financial statements prepared by non-bank credit institutions often do not provide enough information to enable a consumer to form an opinion about an institution's portfolio quality or level of sustainability. This is particularly true for microfinance institutions that pursue a social mission that is often supported by grants or soft loans. It is also true, in general, for financial institutions that use loan methods different from those of banks. Thus, it is important that non-bank credit institutions present information that is meaningful, clear and comparable. For example, CGAP has developed a useful set of guidelines for the content of financial reporting for microfinance institutions. ${ }^{90}$

\section{Customer Account Handling and Maintenance}

\section{C.1. Statements}

a. Unless a non-bank credit institution receives a customer's prior signed authorization to the contrary, the non-bank credit institution should issue, and provide the customer with, a monthly statement regarding every account the non-bank credit institution operates for the customer.

b. Each such statement should: (i) set out all transactions concerning the account during the period covered by the statement; and (ii) provide details of the interest rate(s) applied to the account during the period covered by the statement.

c. Each credit card statement should set out the minimum payment required and the total interest cost that will accrue, if the cardholder makes only the required minimum payment.

d. Each mortgage or other loan account statement should clearly indicate the amount paid during the period covered by the statement, the total outstanding amount still owing, the allocation of payment to the principal and interest and, if applicable, the up-to-date accrual of taxes paid.

e. A non-bank credit institution should notify a customer of long periods of inactivity of any account of the customer and provide reasonable final notice in writing to the customer if the funds are to be transferred to the government.

f. When a customer signs up for paperless statements, such statements should be in an easy-toread and readily understandable format.

Statements can be regarded as the most valid record and evidence of a transaction for a customer. Thus, statements need to be self-explanatory and clear. This is particularly important in the case of credit card statements and loan accounts statements that carry finance charges, penalty interest and serious consequences of default or delayed payment. With increased use of internet and mobile banking, some customers may opt to receive statements on a quarterly rather than monthly basis. The choice should be left to customers. Also, when customers choose paperless statements, the access to the statements, their format and details should be a fair substitute to paper statements. 


\section{C.2. Notification of Changes in Interest Rates and Non-interest Charges}

a. A customer of a non-bank credit institution should be notified in writing by the non-bank credit institution of any change in:

i. the interest rate to be paid or charged on any account of the customer as soon as possible; and

ii. a non-interest charge on any account of the customer a reasonable period in advance of the effective date of the change.

b. If the revised terms are not acceptable to the customer, he or she should have the right to exit the contract without penalty, provided such right is exercised within a reasonable period.

c. The non-bank credit institution should inform the customer of the foregoing right whenever a notice of change under paragraph a. is made by the institution.

Credit institutions in several countries provide from 1 to 3 months of notice, depending on the agreement. In cases where the interest rate is variable and linked to a daily reference rate that is widely published (e.g. LIBOR), the minimum notice to be given of a change in the rate should be stated in the loan agreement. Interest rate increases that do not comply with the contractually stipulated notice must, therefore be, invalid and not binding on the consumer. The code of conduct should include this requirement. A consumer's right to exit a contract is taken from Guidelines 17 and 19 of the UN Guidelines for Consumer Protection.

\section{C.3. Customer Records}

a. A non-bank credit institution should maintain up-to-date records in respect of each customer of the non-bank credit institution that contain the following:

i. a copy of all documents required to identify the customer and provide the customer's profile;

ii. the customer's address, telephone number and all other customer contact details;

iii. any information or document in connection with the customer that has been prepared in compliance with any statute, regulation or code of conduct;

iv. details of all products and services provided by the non-bank credit institution to the customer;

v. a copy of all correspondence from the customer to the non-bank credit institution and vice-versa and details of any other information provided to the customer in relation to any product or service offered or provided to the customer;

vi. all documents and applications of the non-bank credit institution completed, signed and submitted to the non-bank credit institution by the customer;

vii. a copy of all original documents submitted by the customer in support of an application by the customer for the provision of a product or service by the non-bank credit institution; and

viii. any other relevant information concerning the customer.

b. A law or regulation should provide the minimum permissible period for retaining all such records and, throughout this period, the customer should be provided ready free access to all such records.

The list above may seem prescriptive, but the requirements should be regarded as the minimum in order to ensure that sufficient information is kept for the purpose of providing customer protection. For more information, see annotation on good practice C.2.

\section{C.4. Credit Cards}

a. There should be clear rules on the issuance of credit cards and related customer disclosure requirements. 
b. Non-bank credit institutions, as credit card issuers, should ensure that personalized disclosure requirements are made in all credit card offers, including fees and charges (including finance charges), credit limit, penalty interest rates and method of calculating the minimum monthly payment.

c. Non-bank credit institutions should not be permitted to impose charges or fees on preapproved credit cards that have not been accepted by the customer.

d. Consumers should be given personalized minimum payment warnings on each monthly statement and the total interest costs that will accrue if the cardholder makes only the requested minimum payment.

e. Among other things, the rules should also:

i. restrict or impose conditions on the issuance and marketing of credit cards to young adults who have no independent means of income;

ii. require reasonable notice of changes in fees and interest rates increase;

iii. prevent the application of new higher penalty interest rates to the entire existing balance, including past purchases made at a lower interest rate;

iv. limit fees that can be imposed, such as those charged when consumers exceed their credit limits;

v. prohibit a practice called "double-cycle billing" by which card issuers charge interest over two billing cycles rather than one;

vi. prevent credit card issuers from allocating monthly payments in ways that maximize interest charges to consumers; and

vii. limit up-front fees charged on sub-prime credit cards issued to individuals with bad credit.

f. There should be clear rules on error resolution, reporting of unauthorized transactions and of stolen cards, with the ensuing liability of the customer being made clear to the customer prior to his or her acceptance of the credit card.

g. Non-bank credit institutions and issuers should conduct consumer awareness programs on the misuse of credit cards, credit card over-indebtedness and prevention of fraud.

Credit cards are progressively replacing hard currency in many countries. The credit card industry has also been in the limelight for its harmful practices, lack of transparency and inadequate disclosure of terms and conditions of credit card accounts. This is a particular problem in countries with low rates of savings and high consumer spending, as well as in countries where low-income consumers have easier access to finance by acquiring credit cards offered by retailers, consumer finance companies, microfinance providers and other non-bank credit institutions. The recent measures taken by many countries ${ }^{91}$ to update the rules applicable to credit cards clearly indicate the importance of consumer protection in these respects.

Consumers should get key information about credit card terms in a clear and conspicuous format and at a time when it is most useful to them. Anyone under 21 should get an adult to co-sign on the account if he or she wants to open his or her own credit card account or show proof that he or she has his or her own independent means to repay the card debt. Billing methods and information disclosed in the monthly statement should be clear and help customers to make informed choices on their indebtedness.

The increasing use of credit cards over the internet and outside the issuers' jurisdiction increases the incidence of stolen cards and fraud. Thus, improving consumer awareness and knowledge of these problems is important. 


\section{C.5. Debt Recovery}

a. All non-bank credit institutions, agents of a non-bank credit institutions and third parties should be prohibited from employing any abusive debt collection practice against any customer of the non-bank credit institution, including the use of any false statement, any unfair practice or the giving of false credit information to others.

b. The type of debt that can be collected on behalf of a non-bank credit institution, the person who can collect any such debt and the manner in which that debt can be collected should be indicated to the customer of the non-bank credit institution when the credit agreement giving rise to the debt is entered into between the non-bank credit institution and the customer.

c. A debt collector should not contact any third party about a non-bank credit institution customer's debt without informing that party of: (i) the debt collector's right to do so, and (ii) the type of information that the debt collector is seeking.

d. Where sale or transfer of debt without borrower consent is allowed by law, the borrower should be:

i. notified of the sale or transfer within a reasonable number of days;

ii. informed that the borrower remains obligated on the debt; and

iii. provided with information as to where to make payment, as well as the purchaser's or transferee's contact information.

In a number of countries, weak safeguards against abusive debt collection: (i) strengthens the call for a more cumbersome recovery process, (ii) leads to moratoriums on collection, and (iii) earns the sympathy of courts. As a result, debt collection becomes a prolonged process that increases the cost of financing in the long run. Sound rules on debt collection are required so as to help ensure that consumers are not subject to abusive and illegal collection practices.

While some countries rely on the sanctity of the contract and on the courts to uphold the right of borrower and to prevent abuses by lenders, other countries deal with this issue through the law, a directive of a regulator, or guidance provided by a consumer protection agency (see: the US Fair Debt Collection Practices Act, as well as the US Federal Trade Commission (FTC) and the UK Financial Services Authority (FSA) websites).

\section{Privacy and Data Protection}

\section{D.1. Confidentiality and Security of Customers' Information}

a. The financial transactions of any customer of a non-bank credit institution should be kept confidential by the institution.

b. The law should require non-bank credit institutions to ensure that they protect the confidentiality and security of personal data of their customers against any anticipated threats or hazards to the security or integrity of such information, and against unauthorized access.

The confidentiality of personally identifiable information, that is, any information about an identified or identifiable individual, is protected under several international statutes. These include the OECD Guidelines on the Protection of Privacy and Transborder Flows of Personal Data (Article 2 Scope of Guidelines) and the UN Guidelines for the regulation of computerized personal data files adopted by the General Assembly on 14 December 1990 (Section A, Principles concerning the minimum guarantees that should be provided in national legislations).

Other important statutes are included in the EU Directive on the Protection of Individuals with regard to the Processing of Personal Data and on the Free Movement of such data 1995/46/EC (Chapter 1, Articles 1-3); the COE Convention for the Protection of Individuals with regard to 
Automatic Processing of Personal Data (ETS No.108, 28 January 1981, Chapter 1 General Provisions); and the APEC Privacy Framework (Part ii, Scope).

Technical security is also demanded under the above guidelines and directives. The OECD Guidelines for the Security of Information Systems and Networks: Towards a Culture of Security offer a more detailed guideline on technical security.

In the US, the FTC has issued the Standards for Safeguarding Customer Information (2002), which obligates financial institutions to hold customer information secure and confidential. ${ }^{92}$

\section{D.2. Credit Reporting}

a. Credit reporting should be subject to appropriate oversight, with sufficient enforcement authority.

b. The credit reporting system should have accurate, timely and sufficient data. The system should also maintain rigorous standards of security and reliability.

c. The overall legal and regulatory framework for the credit reporting system should be: (i) clear, predictable, non-discriminatory, proportionate and supportive of consumer rights; and (ii) supported by effective judicial or extrajudicial dispute resolution mechanisms.

d. Proportionate and supportive consumer rights should include the right of the consumer:

i. to consent to information-sharing based upon the knowledge of the institution's information-sharing practices;

ii. to access his or her credit report free of charge (at least once a year), subject to proper identification;

iii. to know about adverse action in credit decisions or less-than-optimal conditions/prices due to credit report information;

iv. to be informed about all inquiries within a period of time, such as six months;

v. to correct factually incorrect information or to have it deleted and to mark (flag) information that is in dispute;

vi. to reasonable retention periods of credit history; and

vii. to have information kept confidential and with sufficient security measures in place to prevent unauthorized access, misuse of data, or loss or destruction of data.

e. The credit registers, regulator and associations of non-bank credit institutions should undertake campaigns to inform and educate the public on the rights of consumers in the above respects, as well as the consequences of a negative personal credit history.

Credit reporting systems are designed to reduce credit risk and improve access to credit by keeping a detailed record of each consumer's credit behavior. Transparency of credit reporting systems is important for good governance of these systems. At the same time, controls should exist to protect personal data. Credit reporting is becoming an ever more pervasive activity affecting every consumer's economic life by determining the extent of his or her access, if any, to finance and the terms of any eventual loan agreement that he or she may receive. It is critically important that non-bank credit institutions participate in the credit reporting system so that the credit reports of consumers include information of all their credit transactions in the financial system. The Good Practice incorporates the General Principles for Credit Reporting, developed by the Credit Reporting Standards Setting Task Force, coordinated by the World Bank. 


\section{E. Dispute Resolution Mechanisms}

\section{E.1. Internal Complaints Procedure}

Complaint resolution procedures should be included in the non-bank credit institutions' code of conduct and monitored by the supervisory authority.

Non-bank credit institutions should have written policies in place for the proper handling and resolution of any customer complaint. A written policy will hold the non-bank credit institution liable for the announced policy. This policy should offer contact points for the consumer that are accessible during business hours without undue waiting times, state in plain language the main steps of customer dispute resolution, provide firm and reasonable timelines, guarantee fairness in handling the customer dispute, state the coordination with any ombudsman and/or supervisory authority, and explain in plain language the consumer's rights in the process. Consumer dispute settlement should not lead to unreasonable costs in terms of time and money for the consumer. Robust internal complaints procedures improve customer relationships, increase trust in the nonbank credit institutions and reduce the cost of adjudication.

\section{E.2. Formal Dispute Settlement Mechanisms}

a. A system should be in place that allows consumers to seek affordable and efficient third-party recourse, such as an ombudsman, in the event the complaint with the non-bank credit institution is not resolved to the consumer's satisfaction in accordance with internal procedures.

b. The role of an ombudsman or equivalent institution in dealing with consumer disputes should be made known to the public.

c. The ombudsman or equivalent institution should be impartial and act independently from the appointing authority, the industry and the parties to the dispute.

d. The decisions of the ombudsman or equivalent institution should be binding upon non-bank credit institutions. The mechanisms to ensure the enforcement of these decisions should be established and publicized.

Few customers have the knowledge to realize that their rights have been infringed and, even if they are aware of the infringement, they typically have very few avenues to pursue their claims. If the consumer raises a complaint with the non-bank credit institution and it is not resolved to the consumer's satisfaction, consumers usually do not have many venues to seek fast and inexpensive redress. Thus, several non-bank credit institutions around the world are seeking to participate in ombudsman schemes to deal expeditiously, independently, professionally and inexpensively with consumer disputes that do not get resolved internally by the institutions. The establishment and sustainability of such schemes are regarded as fundamental requirements for sound consumer protection. Ombudsman schemes can also identify complaints that are few in number but high in importance for consumer confidence in the financial sector, thereby enabling the relevant authorities to take effective action to remedy the situation.

\section{F. Consumer Empowerment \& Financial Literacy}

\section{F.1. Broadly based Financial Literacy Program}

a. A broadly based program of financial education and information should be developed to increase the financial literacy of the population.

b. A range of organizations-including government, state agencies and non-governmental organizations-should be involved in developing and implementing the financial literacy program. 
c. The government should appoint an institution such as the central bank or a financial regulator to lead and coordinate the development and implementation of the national financial literacy program.

Financial education, information and guidance can help consumers to budget and manage their income, to save, invest and protect themselves against risks, and to avoid becoming victims of financial fraud and scams. As financial products and services become more sophisticated and households assume greater responsibility for their financial affairs, it becomes increasingly important for individuals to manage their money well, not only to help secure their own and their family's financial well-being, but also to facilitate the smooth functioning of financial markets and the economy.

Many organizations in both the public and private sector have an interest in improving people's financial literacy. They should work together on this issue, so that there is a range of initiatives which, over time, will help to drive up people's ability to manage their personal finances.

\section{F.2. Using a Range of Initiatives and Channels, including the Mass Media}

a. A range of initiatives should be undertaken by the relevant authority to improve the financial literacy of the population, and especially from low-income communities.

b. The mass media should be encouraged by the relevant authority to provide financial education, information and guidance to the public, including on non-bank credit institutions and the products and services they offer.

c. The government should provide appropriate incentives and encourage collaboration between governmental agencies, the supervisory authority for non-bank credit institutions, the associations of non-bank credit institutions and consumer associations in the provision of financial education, information and guidance to consumers.

A range of financial literacy initiatives should be developed, including targeted programs aimed at young people, entrepreneurs, farmers, local community chiefs, employees, as well as using several delivery channels including Internet, radio, television, publications, etc.

The media - especially television and radio- can play an important role in providing financial education and information. This is particularly true in low-income communities, where radio is generally more widely accessed than television or internet, and in many cases sections of newspapers are entirely read in radio programs. Regulators and industry associations can support initiatives by providing the media with information about current concerns and about different types of financial services and products.

\section{F.3. Unbiased Information for Consumers}

a. Consumers, especially the most vulnerable, should have access to sufficient resources to enable them to understand financial products and services available to them.

b. Supervisory authorities and consumer associations should provide, via the internet and printed publications, independent information on the key features, benefits and risks - and, where practicable, the costs - of the main types of financial products and services, including those offered by non-bank credit institutions.

c. The relevant authority should adopt policies that encourage non-government organizations to provide consumer awareness programs to the public regarding financial products and services, including those offered by non-bank credit institutions.

Consumers and potential consumers are more likely to have the confidence to purchase financial products and services which are suitable for them if they have access to information which is 
reliable and objective. The authorities supervising non-bank credit institutions have a role to play in this area, either directly providing unbiased information about the sector, or coordinating with other financial regulators and non-government organizations, to make sure that information of the non-bank credit sector is included in consumer awareness programs as well as printed and online publications.

\section{F.4. Consulting Consumers and the Financial Services Industry}

The relevant authority should consult consumer associations and associations of non-bank credit institutions to help the authority develop financial literacy programs that meet the needs and expectations of financial consumers, especially those served by non-bank credit institutions.

In developing financial literacy programs, consultations will be helpful in order to take into account the perspectives of consumers, particularly those from non-bank credit institutions, as well as the perspectives of financial institutions and their trade associations. In countries where there are informed and effective consumer associations, they will also need to be consulted.

To ensure that consumers are actively involved in the policy development process, it is recommended that the government or private sector organizations or both provide appropriate funding to non-government organizations for this purpose.

\section{F.5. Measuring the Impact of Financial Literacy Initiatives}

a. Policymakers, industry and consumer advocates should understand the financial literacy of various market segments, particularly those most vulnerable to abuse.

b. The financial literacy of consumers should be measured, amongst other things, by broadly based household surveys that are repeated from time to time.

c. The effectiveness of key financial literacy initiatives should be evaluated by the relevant authority from time to time.

In order to measure the impact of financial education and information initiatives, the financial literacy of a sample of the population should be measured by means of large-scale market research that gets repeated from time to time. Initiatives will take some time to have a measurable impact on the financial literacy of a population, so it is likely to be sufficient to repeat the survey every four to five years.

In addition, key financial literacy initiatives should be evaluated to assess their impact on those people they are intended to reach. This can help policymakers and funders to decide, on an informed basis, which initiatives should be continued (and perhaps scaled up) and which should be modified or discontinued. 
Table 8 provides a summary of key regulation for non-bank credit institutions.

Table 8: Overview of Consumer Protection Regulation for Non-Bank Credit Institutions

\begin{tabular}{|c|c|}
\hline $\begin{array}{l}\text { Institution or } \\
\text { Government }\end{array}$ & Laws, Regulations, Directives and Guidelines \\
\hline UN & $\begin{array}{l}\text { UN Guidelines for the Regulation of Computerized Personal Data Files adopted by } \\
\text { the General Assembly Resolution 45/95 of } 14 \text { December } 1990\end{array}$ \\
\hline OECD & $\begin{array}{l}\text { Guidelines for the Security of Information Systems and Networks: Towards a } \\
\text { Culture of Security, } 2002 \\
\text { Guidelines on the Protection of Privacy and Transborder Flows of Personal Data, } \\
1980\end{array}$ \\
\hline BIS & $\begin{array}{l}\text { Basel Committee on Banking Supervision, Consolidated KYC Risk Management, } \\
\text { October } 2004 \\
\text { Basel Committee on Banking Supervision, Customer Due Diligence for Banks, } \\
\text { October } 2001\end{array}$ \\
\hline APEC & APEC Privacy Framework, 2005 \\
\hline EU & $\begin{array}{l}\text { Directive on Consumer Credit, 1998/7/EC, amending Directive 87/102/EEC } \\
\text { Directive on Consumer Credit, 2008/48/EC } \\
\text { Directive on Credit Agreements for Consumers, 2008/48/EC, repealing Directive } \\
87 / 102 / E E C \\
\text { Directive on Unfair Terms in Consumer Contracts, 1993/13/EEC } \\
\text { Directive concerning Unfair Business-to-Consumer Commercial Practices in the } \\
\text { Internal Market, 2005/29/EC } \\
\text { Directive on the Protection of Individuals with regard to the Processing of Personal } \\
\text { Data and on the Free Movement of such data, 1995/46/EC } \\
\text { Directive Concerning Processing Personal Data and Protection of Privacy in the } \\
\text { Electronic Communication Sector, 2002/58/EC } \\
\text { Directive on Protection of Consumers in Respect of Distance Contracts, 1997/7/EEC } \\
\text { Directive on the Distance Marketing of Consumer Financial Services, 2002/65/EC } \\
\text { Directive on Markets in Financial Instruments, 2004/39/EC (MiFID) } \\
\text { Treaty establishing the European Community (EC Treaty), } 1957 \text { as amended }\end{array}$ \\
\hline COE & $\begin{array}{l}\text { Convention for the Protection of Individuals with regard to Automatic Processing of } \\
\text { Personal Data (ETS No.108 of } 28 \text { January 1981, entered into force on } 01 \text { October } \\
\text { 1985) and Explanatory Report }\end{array}$ \\
\hline US & 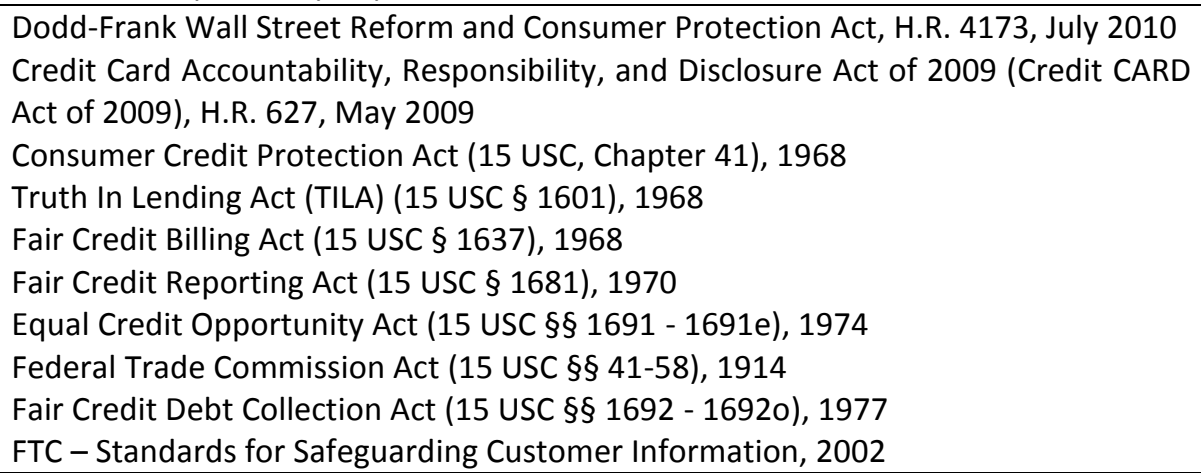 \\
\hline
\end{tabular}




\section{References}

Akerlof, George A., “'The Market for Lemons': Quality Uncertainty and the Market Mechanism” Quarterly Journal of Economics, 1970.

Alliance for Financial Inclusion, Consumer Protection: Leveling the playing field in financial inclusion, Policy Note, 2010

Anagol, Santosh, Shawn Cole, and Shayak Sarkar, Bad Advice: Explaining the Persistence of Whole Life Insurance, February 2011

Ardic, Oya Pinar, Joyce Ibrahim and Nataliya Mylenko, Consumer Protection Laws and Regulations in Deposit and Loan Services: A Cross-Country Analysis with a New Data Set, Policy Research Working Paper No. 5536, World Bank, January 2011

Armstrong, Mark, "Interactions between Competition and Consumer Policy", Competition Policy International, Volume 4, Number 1, Spring 2008

Asian Development Bank Institute, Hannig, Alfred and Jansen, Stefan, Financial Inclusion and Financial Stability: Current Policy Issues, ADBI Working Paper Series No. 259, December 2010

Australian Government Publishing Service, The Financial System Inquiry Final Report ("Wallis Report”), March 1997

Bakker, Marie Renée and Alexandra Gross, Development of Non-bank Financial Institutions and Capital Markets in European Union Accession Countries, World Bank Working Paper No. 28, World Bank, February 2004

Bellman, S., E. J. Johnson, G. L. Lohse, "On site: to opt-in or opt-out?: It depends on the question, Communications of the ACM, Volume 44 , Issue 2 25-27, February 2001.

Bank for International Settlements, Committee on Payment and Settlement Systems, Retail Payment Systems in Selected Countries: a Comparative Study, September 1999

--------, Clearing and Settlement Arrangements for Retail Payments in Selected Countries, September 2000

--------, Policy Issues for Central Banks in Retail Payments, March 2003

---------, General Guidance for National Payment System Development, January 2006

Bank for International Settlements, Committee on Payment and Settlement Systems, and World Bank, General Principles for International Remittance Services, January 2007

Benston, George, "Consumer Protection as Justification for Regulating Financial Services Firms and Products", Journal of Financial Services Research, 17(3): 277-301, 2000

Block-Lieb, Susan, Best Practices in the Insolvency of Natural Persons, The World Bank Insolvency and Creditor/Debtor Regimes task Force Meetings, Rapporteur's Synopsis, January 2011 
Brix, Laura and Katharine McKee, Consumer Protection Regulation in Low-Access Environments: Opportunities to Promote Responsible Finance, CGAP Focus Note No. 60, February 2010.

Brown, Sarah, G. Garino, K. Taylor and S. W. Price, Debt and financial expectations: An individual and household level analysis, Working Paper No. 03/05, University of Leicester, February 2004

California Budget Report, Locked Out 2008: The Housing Boom and Beyond, February 2008

Centre for European Policy Studies and Van Dijk Management Consultants, Tying and other potentially unfair commercial practices in the retail financial service sector, Final Report submitted to the European Commission, DG Internal Market and Services, ETD/2008/IM/H3/78, November 2009

Center for the Study of Financial Innovation, Microfinance Banana Skins 2011: The CSFI survey of microfinance risk: Losing its fairy dust, February 2011

Cirasino, Massimo, "The Committee on Payment and Settlement Systems and the World Bank General Principles on International Remittance Services", AccessFinance, Issue No. 11, May 2006

Cirasino, Massimo, Jose A. Garcia, Mario Guadamillas and Fernando Montes-Negret, Reforming Payments and Securities Settlement Systems in Latin America and the Caribbean, World Bank, 2007

Cole, Shawn and Gauri Kartini Shastry, If You Are So Smart, Why Aren't You Rich? The Effects of Education, Financial Literacy, and Cognitive Ability on Financial Market Participation, October 2007

Collins, Daryl, Nicola Jentzsch and Rafael Mazer, Incorporating Consumer Research into Consumer Protection Policy Making, CGAP Focus Note No. 74, November 2011

Consultative Group to Assist the Poor, Advancing Financial Access for the World's Poor: Annual Report 2011, 2012

Consultative Group to Assist the Poor/The World Bank Group, Financial Access 2010: The State of Financial Inclusion Through the Crisis, September 2010

Consumers International, Safe, fair and competitive markets in financial services: recommendations for the $G 20$ on the enhancement of consumer protection in financial services, March 2011

--------, Financial education counselling - Counsellor's handbook, January 2012

Deb, Anamitra and Mike Kubzansky, Bridging the Gap: The Business Case for Financial Capability, Citi Foundation, March 2012.

Demirguc-Kunt, Asli and Klapper, Leora, Measuring Financial Inclusion: The Global Findex Database, World Bank Policy Research Working Paper No. 6025, World Bank, 2012

European Commission, Communication on Financial Education COM (2007) 808 
--------, Discussion paper for the amendment of Directive 87/102/EEC concerning consumer credit, 2001

--------, EU Consumer Policy strategy 2007-2013 COM (2007) 99 final, March 2007

--------, Eurobarometer 2003.5, Financial Services and Consumer Protection, May 2004

--------, Green Paper on Retail Financial Services in the Single Market, COM (2007) 226 final, April 2007

--------, Special Eurobarometer No. 252, Consumer protection in the Internal Market, September

2006

--------, Survey of Financial Literacy Schemes in the EU27, November 2007

--------, Directorate-General for Competition, Report on the retail banking inquiry, Commission Staff Working Document, SEC (2007) 106, January 2007

European Parliament, Report on Improving consumer education and awareness on credit and finance (2007/2288(INI)), 18 November 2008

Fardoust, Shahrokh, Yongbeom Kim and Claudia Sepúlveda (eds), Post-Crisis Growth and Development: A Development Agenda for the G-20, World Bank, November 2010

Financial Services Authority, The Turner Review: A regulatory response to the global banking crisis, March 2009

Financial Stability Board, Consumer Finance Protection with particular focus on credit, 26 October 2011

FIN-USE, Response to the Green Paper on Retail Financial Services in the Single Market, 2007

Grifoni, A. and Messy, F., Current Status of National Strategies for Financial Education: A Comparative Analysis and Relevant Practices, OECD Working Papers on Finance, Insurance and Private Pensions, No. 16, OECD Publishing, 2012

Gross, Karen, "Financial Literacy Education: Panacea, Palliative, or Something Worse?", St. Louis University Public Law Review 24(2): 307-312, 2005

Group of Thirty, Financial Reform: A Framework for Financial Stability, January 2009

Hadfield, Gillian K, Robert Howse and Michael J Trebilcock, "Information-Based Principles for Rethinking Consumer Protection Policy” Journal of Consumer Policy 21: 131-169, 1998

Herring, Richard J. and Anthony M. Santomero, "What is Optimal Financial Regulation?", Wharton Financial Institutions Center Working Paper Series, Working Paper No/ 00-34, May 1999

Hilgert, Marianne A. and Jeanne M. Hogarth, "Household Financial Management: The Connection between Knowledge and Behavior", Federal Reserve Bulletin, July 2003

International Finance Corporation, Credit Bureau Knowledge Guide, 2006

---------, Global Practices in Responsible and Ethical Collections, IFC Working Paper, August 2009

International Monetary Fund, Independent Evaluation Office, IMF Performance in the Run-Up to the Financial and Economic Crisis: IMF Surveillance in 2004-07, January 2011 
Jentzsch, Nicola, Financial Privacy - An International Comparison of Credit Reporting Systems, October 2007

Joint Forum of Basel Committee on Banking Supervision, International Organization of Securities Commission and International Association of Insurance Supervisors, Customer suitability in the retail sale of financial products and services, April 2008

Klapper, Leora and Georgios Panos, Financial Literacy and Retirement Planning: The Russian Case, August 2011

Klapper, Leora, Annamaria Lusardi and Georgios Panos, Financial Literacy and the Financial Crisis, Evidence from Russia, March 2011

Llewellyn, David T., "The Economic Rationale for Financial Regulation, Financial Services Authority", FSA Occasional Papers in Financial Regulation, No. 1:1-57, April 1999

Loewenstein, George, T. O'Donoghue and M. Rabin, "Projection Bias in Predicting Future Utility”, Quarterly Journal of Economics 118 (4): 1209-1248, 2003

Lusardi, Annamaria and Olivia Mitchell, "Financial Literacy and Retirement Preparedness: Evidence and Implications for Financial Education", Business Economics 42 (1): 35-44, January 2007

Mandell, Lewis, Financial Literacy: Are We Improving? Results of the 2004 National Jump\$tart Survey, Jump\$tart Coalition for Personal Financial Literacy, 2004

--------, The Financial Literacy of Young American Adults: Results of the 2008 National Jump\$tart Coalition Survey of High School Seniors and College Students, Jumpstart Coalition, 2009

McKay, Claudia and Mark Pickens, Branchless Banking 2010: Who's Served? At What Price? What's Next? CGAP Focus Note No. 66, September 2010

Miller, Margaret J. (ed.), Credit Reporting Systems and the International Economy, Massachusetts Institute of Technology, 2003

Mundy, Shaun, Financial Education in Schools: Analysis of Selected Current Programmes and Literature - Draft Recommendations for Good Practices, in proceedings of OECD-US Treasury International Conference on Financial Education, Washington DC, 7-8 May 2008, Volume II

Nier, Erlend Walter, Financial Stability Frameworks and the Role of Central Banks: Lessons from the Crisis, IMF Working Paper WP/09/70, International Monetary Fund, April 2009

Organisation for Economic Co-operation and Development, Guidelines for Protecting Consumers from Fraudulent and Deceptive Commercial Practices Across Borders, 2003

---------, Improving Financial Literacy: Analysis of Issues and Policies, 2005

--------, Recommendation of the Council on Principles and Good Practices for Financial Education and Awareness, 2005

--------, Best Practices for Consumer Policy: Report on the Effectiveness of Enforcement Regimes, 2006 
---------, Policy Guidance For Addressing Emerging Consumer Protection And Empowerment Issues In Mobile Commerce, 2007

---------, Consumer Education, 2007

--------, Financial Literacy and Consumer Protection: Overlooked Aspects of the Crisis, 2008

---------, Improving Financial Education And Awareness On Insurance And Private Pensions, 2008

---------, Recommendation of the Council on Good Practices for Financial Education related to Private Pensions, 2008

--------, Recommendation of the Council on Good Practices for Enhanced Risk Awareness and Education on Insurance Issues, 2008

--------, Consumer Education: Policy Recommendations of the OECD's Committee on Consumer Policy, 2009

---------, Financial Consumer Protection, 2009

---------, Insurance Intermediaries And Financial Education And Protection Of Consumers, 2009

----------, Issue Note On Insurance Intermediaries And Consumers' Insurance Education And Protection 2009

--------, OECD Strategic Response To The Global Financial And Economic Crisis: Consumer Issues, 2009

--------, Preliminary Draft Good Practices on Insurance Intermediaries and Consumers Insurance Education and Protection, 2009

--------, Recommendation of the Council on Good Practices on Financial Education and Awareness relating to Credit, 2009

---------, Addressing Financial Consumer Protection Deficiencies in the Post Crisis Era, 2010

---------, Consumer Protection And Financial Innovation: A Few Basic Propositions, 2010

---------, Protecting and Empowering Consumers in the Internet Economy Options for Advancing the Review of the 1999 OECD Guidelines, 2010

Rajan, Raghuram G., Has Financial Development Made the World Riskier? NBER Working Paper No. 11728, National Bureau of Economic Research, November 2005

-------, Fault Lines: How Hidden Fractures Still Threaten the World Economy, Princeton University Press, 2010

Rekaiti, Pamaria and Roger Van den Bergh, "Cooling-Off Periods in the Consumer Laws of the EC Member States. A Comparative Law and Economics Approach", Journal of Consumer Policy 23(4): 371-408, November 2004

Responsible Finance Forum, Advancing Responsible Finance for Greater Development Impact: A Stock-Taking of Strategies and Approaches among Development Agencies and Development Finance Institutions, Consultation Draft, January 27, 2011

Rutledge, Susan L., Consumer Protection and Financial Literacy: Lessons from Nine Country Studies, Policy Research Working Paper No. 5326, World Bank, June 2010

--------, Country Studies Provide Powerful Lessons in Financial Consumer Protection, Knowledge Brief No. 26, World Bank, July 2010

Rutledge, Susan L, N. Annamalai, R. Lester and R. Symonds., Good Practices for Consumer Protection and Financial Literacy in Europe and Central Asia: A Diagnostic Tool, ECSPF Working Paper 001, World Bank, August 2010

Task Force on Financial Literacy, Report of Recommendations on financial literacy, Canadians and their money: Building a brighter future, December 2010 
Taylor, Curtis R., "Consumer Privacy and the Market for Customer Information", RAND Journal of Economics, 35 (4): 631-50, 2004

Thomas, David and Frizon, Francis, Resolving disputes between consumers and financial businesses: Fundamentals for a financial ombudsman - A practical guide based on experience in western Europe, World Bank, 2012

, Resolving disputes between consumers and financial businesses: Current arrangements in central and eastern Europe, World Bank, 2012

Tiwari, Akhand, Anvesha Khandelwal and Minakshi Ramji, How Do Microfinance Clients Understand their Loans?, Centre for Micro Finance at the Institute for Financial Management and Research, Chennai, India, October 2008

UK Financial Services Authority, Reforming Conduct of Business Regulation, Consultation Paper, October 2006

--------, The Turner Review: A regulatory response to the global banking crisis, March 2009

US Department of Housing and Urban Development and Department of Treasury Joint Task Force, Curbing Predatory Home Mortgage Lending, June 2000

United Nations, Department of Economic and Social Affairs, United Nations Guidelines for Consumer Protection (as expanded in 1999), 1999

Weinstein, Neil, "Unrealistic Optimism About Future Life Events", Journal of Personality and Social Psychology 39(5): 806-820, 1980

Willis, Lauren E., "Against Financial Literacy Education”, University of Pennsylvania Law School, Public Law and Legal Theory Research Paper Series, Research Paper No. 08-10, November 2008

World Bank, Finance for All? Policies and Pitfalls in Expanding Access, 2008

-------, General Principles for Credit Reporting, September 2011

--------, Migration and Remittances Factbook 2011, November 2010

--------, Principles for Effective Insolvency and Creditor/Debtor Regimes, January 2011

--------, Report on the Treatment of Insolvency of Natural Persons - Working Group on the Treatment of the Insolvency of Natural Persons, World Bank, Nov 2011 (forthcoming)

World Bank Group, Financial and Private Sector Development Vice Presidency, Payment Systems Development Group, Payment Systems Worldwide: a Snapshot. Outcomes of the Global Payment Systems Survey 2008, 2008 


\section{Annex I: Private Pensions Sector}

Pensions plans are typically the largest single financial investment for households and, in the absence of strong consumer protection, households may find their plans are inadequate to meet their retirement income needs. However, work on consumer protection in private pensions remains at a nascent stage ${ }^{93}$. What regulation there is tends to be country-specific and, following a number of scandals (e.g. Enron) and the financial crisis of 2007-09, a number of assumptions underlying the role and structuring of supplementary pensions need to be reviewed.

The pensions sector has a number of attributes that need to be considered in designing an appropriate consumer protection regime. These include the following:

- Pension savings may be compulsory under a $2^{\text {nd }}$ pillar ${ }^{94}$ or an equivalent.

- Where the member is fortunate enough to be in one of the surviving defined benefit arrangements, the funding level may not be subject to normal actuarial standards (e.g. public sector arrangements in a number of countries).

- The member/ affiliate may have little or no say in how the pension plan is funded, invested, administered or governed if the plan is employer-based (i.e. an occupational arrangement).

- The plan may be governed under a trustee arrangement or governance may be left entirely to the employer working through the managing institutions.

- The system needs to allow for both accumulation and decumulation life cycle stages. To date many countries have focused entirely on the accumulation stage, partly because a secondary objective in developing pension systems has been the development of capital markets.

Based on the lack of an agreed approach, the Good Practices employed in private pension assessments to date have relied on practices in use for the insurance sector (especially related to defined benefit plans and life annuities) and the securities sector (for defined contribution plans and investment funds). Recent experience has demonstrated, however, that other issues are at least as important for consumer protection in private pensions including, critically, the need to understand the roles of risk and lifecycle stage in determining appropriate investment and funding strategies.

Other pension specific issues include: (1) flexibility and options for consumers to switch among service providers of pension plans (pension management companies), (2) the terms and conditions of investment contracts with pension management companies, (3) treatment of the decumulation (pay-out) phase, (4) controls over any fees that are deducted from the pension fund, (5) levels of competition among pension management companies, and (6) portability of full accumulated entitlements when changing employer.

Supervision is also a key issue for consumer protection in private pensions. Pensions may be supervised by the prudential supervisor, or the taxation authorities, or a combination thereof (e.g. Australia, Canada, and Peru). There are also examples of the securities supervisor having responsibility for pensions (e.g. the Russian Federation) or a combination of separate insurance and securities supervisors (e.g. Turkey). With only a few exceptions (such as the US), private pensions are not insured by the state. Thus, no established international approach or even range of approaches currently exists. However, recent ongoing global research has begun to identify Good Practices for private pension arrangements and this will ultimately lead, as with the other financial sector elements, to a consensus. In the interim, the Good Practices noted below provide 
a useful starting point. These have so far been tested in five consumer protection diagnostic reviews (Bulgaria, Croatia, Latvia, Romania and the Russian Federation) carried out by the WBG.

\section{A. Consumer Protection Institutions}

\section{A.1. Consumer Protection Regime}

The law should recognize and provide for clear rules on consumer protection in the area of private pensions and there should be adequate supporting institutional arrangements:

a. There should be specific provisions in the law, which create an effective regime for the protection of consumers who deal directly with pension management companies and members/ affiliates of occupational plans.

b. There should be a general consumer protection agency or a specialized agency, responsible for the implementation, oversight and enforcement of pension consumer protection, as well as data collection and analysis (including inquiries, complaints and disputes).

c. The law should provide, or at least not prohibit, a role for the private sector, including voluntary consumer organizations and self-regulatory organizations, in respect of consumer protection regarding private pensions.

\section{A.2. Other Institutional Arrangements}

a. The judicial system should provide credibility to the enforcement of the rules on pension consumer protection.

b. The media and consumer associations should play an active role in promoting pension consumer protection.

\section{B. Disclosure and Sales Practices}

\section{B.1. General Practices}

a. There should be disclosure principles and practices that cover the consumer's relationship with the pension management company or occupational plan in all three stages of such relationships: pre-sale, point of sale, and post-sale.

b. There should be clear rules on solicitation and issuance of pension products.

c. The information available and provided to the consumer should clearly inform the consumer of the choice of accounts, products and services, as well as the risks associated with each of the options or choices.

d. Employers should be responsible for ensuring that new plan members are made fully aware of their rights and obligations under any occupational pension arrangements.

e. Employers should be required to vest benefits with employees relatively quickly so as to avoid undesirable personnel practices (such as terminating employment just as employer contributions are about to vest).

f. Employers should be obliged to ensure that contributions are properly collected, accounted for and passed on to the pension fund's managers.

\section{B.2. Advertising and Sales Materials}

a. Pension management companies should ensure their advertising and sales materials and procedures do not mislead the customers.

b. All marketing and sales materials of pension management companies should be easily readable and understandable by the average public. 
c. The pension management company should be legally responsible for all statements made in marketing and sales materials related to its products, and for all statements made by any person acting as an agent for the company.

\section{B.3. Key Facts Statement}

A Key Facts Statement disclosing the key factors of the pension scheme and its services should be presented by the pension management company before the consumer signs a contract.

\section{B.4. Special Disclosures}

a. Pension management companies should disclose information relating to the products they offer, including investment options, risk and benefits, fees and charges ${ }^{95}$, any restrictions or penalties on transfer, fraud protection over accounts, and fee on closure of account.

b. Customers should be notified of any planned change in fees or charges a reasonable period in advance of the effective date of the change.

c. Pension management companies should inform consumers upfront of the nature of any guarantee arrangements covering their pension products.

d. Customers should be informed upfront regarding the time, manner and process of disputing information on statements and in respect of transactions.

e. Customers should be informed in writing, at the time of sale or when joining an occupational plan, of the options available to them if they decide to change employer, move or retire.

\section{B.5. Professional Competence}

a. Marketing personnel, officers selling and approving transactions, and agents, should have sufficient qualifications and competence, depending on the complexities of the products they sell.

b. The law should require agents to be licensed, or at least be authorized to operate, by the regulator or supervisor.

c. Personnel departments with responsibility for occupational arrangements should have at least one suitably qualified individual who can explain the plan to members and deal with thirdparty providers such as asset management companies.

\section{B.6. Know Your Customer}

The sales officer should examine important characteristics of any potential customer, such as age, employment prospects and financial position, and be aware of the customer's risk appetite and his or her long-term objectives for retirement, and recommend relevant financial products accordingly.

\section{B.7. Disclosure of Financial Situation}

a. The regulator or supervisor should publish annual public reports on the development, health and strength of the pensions industry either as a special report or as part of its disclosure and accountability requirements under the law that governs these.

b. All pension management companies should disclose information regarding their financial position and profit performance.

c. Actuarial reports on funding levels should be required annually for defined benefit plans and members and affiliates should be advised of the condition of the plan in a short and clear written report.

d. Investment reports for defined contribution plans should at least match best practice mutual fund reporting. 


\section{B.8. Contracts}

There should be consistent contracts or membership forms for pension products and the contents of a contract should be read by the customer or explained to the customer before it is signed. Ideally, the customer should be required to confirm in their own handwriting that they understand the terms of the pension contract plan.

\section{B.9. Cooling-off Period}

There should be a reasonable cooling-off period associated with any individual pension product.

\section{Customer Account Handling and Maintenance}

\section{C.1. Statements}

a. Members and affiliates of a defined contribution pension plan should not be locked into a specified investment profile (and shares in their employer in particular) for more than a short period (e.g. one week) after providing notification of a desire to switch investment profiles.

b. Customers or occupational plan members should receive a regular streamlined statement of their account that provides the complete details of account activity (including investment performance on a standardized basis) in an easy-to-read format, making reconciliation easy.

c. Customers should have a means to dispute the accuracy of any transaction recorded in the statement within a reasonable, stipulated period.

d. When customers sign up for paperless statements, such statements should be in an easy-toread and readily understandable format.

\section{Privacy and Data Protection}

\section{D.1. Confidentiality and Security of Customer's Information}

a. The financial activities of any customer of a pension management company should be kept confidential and protected from unwarranted private and governmental scrutiny.

b. The law should require pension management companies to ensure that they protect the confidentiality and security of personal information of their customers against any anticipated threats or hazards to the security or integrity of such information, and against unauthorized access to, or use of, customer information that could result in substantial harm or inconvenience to any customer.

\section{D.2. Sharing Customer's Information}

a. Pension management companies should inform the consumer of third-party dealings for which the pension management company intends to share information regarding the consumer's account.

b. Pension management companies should explain to customers how they use and share customers' personal information.

c. Pension management companies should be prohibited from selling (or sharing) account or personal information to (or with) any outside company not affiliated with the pension management company for the purpose of telemarketing or direct mail marketing.

d. The law should allow a customer to stop or "opt out" of the sharing by the pension management company of certain information regarding the customer, and the pension management company should inform its customers of their opt-out right.

e. The law should prohibit the disclosure of information of customers by third parties. 
D.3. Permitted Disclosures

a. The law should state specific procedures and exceptions concerning the release of customer financial records to government authorities.

b. The law should provide for penalties for breach of confidentiality laws.

\section{E. Dispute Resolution Mechanisms}

\section{E.1. Internal Dispute Settlement}

a. An internal avenue for claim and dispute resolution practices within the pension management company should be required by the supervisory agency.

b. Pension management companies should provide designated employees available to consumers for inquiries and complaints.

c. The pension management company should inform its customers of the internal procedures on dispute resolution.

d. The regulator or supervisor should investigate whether pension management companies comply with their internal procedures regarding dispute resolution.

\section{E.2. Formal Dispute Settlement Mechanisms}

A system should be in place that allows consumers to seek third-party recourse in the event they cannot resolve a pensions-related issue with their employer or a pension management company.

\section{F. Guarantee Schemes and Safety Provisions}

\section{F.1. Guarantee Schemes and Safety Provisions}

Guarantee and compensation schemes are less common in the pensions sector than in banking and insurance. There are more likely to be fiduciary duties and custodian arrangements to ensure the safety of assets.

a. There needs to be a basic requirement in the law to the effect that pension management companies should seek to safeguard pension fund assets.

b. There should also be adequate depository or custodian arrangements in place to ensure that assets are safeguarded.

\section{G. Consumer Empowerment \& Financial Literacy}

\section{G.1. Using a Range of Initiatives and Channels, including the Mass Media}

a. A range of initiatives should be undertaken to improve people's financial literacy.

b. The mass media should be encouraged by the relevant authority to provide financial education, information and guidance to the public, including on the private pensions sector.

c. The government should provide appropriate incentives and encourage collaboration between governmental agencies, the supervisory authority for private pensions, the private pension industry and consumer associations in the provision of financial education, information and guidance to consumers, particularly on the private pensions sector.

\section{G.2. Unbiased Information for Consumers}

a. Financial regulators and consumer associations should provide, via the internet and printed publications, independent information on the key features, benefits and risks -and where practicable the costs- of the main types of financial products and services, including private pensions. 
b. The relevant authority should adopt policies that encourage non-government organizations to provide consumer awareness programs to the public in the area of pensions.

\section{G.3. Consulting Consumers and the Financial Services Industry}

a. The relevant authority should consult consumer associations and the private pension industry to help the authority develop financial literacy programs that meet the needs and expectations of financial consumers, especially pension fund members and affiliates. 


\section{Annex II: Credit Reporting Systems}

Credit reporting is a crucial component of modern financial systems and a critical driver for efficiency in lending to consumers. Efficient and accurate credit reporting systems provide valuable benefits for consumers, enabling them to obtain increased access to credit at favorable terms and conditions and the ability to monitor their levels of debt to ensure that they avoid high levels of indebtedness. Transparency of credit reporting systems is important for good governance of these systems and, at the same time, controls should exist to protect personal data. Credit reporting is becoming an ever more pervasive activity that affects a consumer's economic life by determining access and terms of financial services. Public policy should find the right balance between consumer data protection and the economic rationale of processing personal information. As of 2011, there were no international Good Practices for consumer protection in credit reporting, although a number of international data protection instruments provide useful guidance (see Table 9).

Table 9: Overview of Consumer Protection Regulation for Credit Reporting Systems

\begin{tabular}{|c|c|}
\hline $\begin{array}{l}\text { Institution or } \\
\text { Government }\end{array}$ & Laws, Regulations, Directives and Guidelines \\
\hline UN & $\begin{array}{l}\text { Art. XII of the Universal Declaration of Human Rights } \\
\text { Art. } 17 \text { of the International Covenant on Civil and Political Rights of } 16 \\
\text { December } 1966 \\
\text { UN Guidelines for the Regulation of Computerized Personal Data Files, adopted } \\
\text { by the General Assembly Resolution 45/95 of } 14 \text { December } 1990\end{array}$ \\
\hline OECD & $\begin{array}{l}\text { Guidelines for the Security of Information Systems and Networks: Towards a } \\
\text { Culture of Security, } 2002 \\
\text { Recommendation of the Council concerning guidelines governing the protection } \\
\text { of privacy and trans-border flows of personal data, adopted by the Council } 23 \\
\text { September } 1980 \\
\text { Guidelines on the Protection of Privacy and Transborder Flows of Personal Data, } \\
1980 \\
\text { Declaration of Transborder Data Flows, } 1985 \\
\text { Ministerial Declaration on the Protection of Privacy on Global Networks, } 1998\end{array}$ \\
\hline World Bank & $\begin{array}{l}\text { Principles and Guidelines for Credit Reporting Systems, } 2004 \\
\text { Principles For Effective Insolvency And Creditor/Debtor Regimes, } 2011 \\
\text { General Principles for Credit Reporting, } 2011\end{array}$ \\
\hline APEC & APEC Privacy Framework, 2005 \\
\hline EU & $\begin{array}{l}\text { Directive on the Protection of Individuals with regard to the Processing of } \\
\text { Personal Data and on the Free Movement of such data, 1995/46/EC } \\
\text { Directive on Credit Agreements for Consumers, 2008/48/EC repealing Directive } \\
\text { 87/102/EEC }\end{array}$ \\
\hline COE & $\begin{array}{l}\text { Convention for the Protection of Individuals with regard to Automatic } \\
\text { Processing of Personal Data (ETS No. } 108 \text { of } 28 \text { January 1981, entered into force } \\
\text { on } 01 \text { October 1985) and Explanatory Report } \\
\text { Amendment to Convention ETS No. } 108 \text { allowing the European Communities to } \\
\text { accede (adopted } 15 \text { June 1999, entered into force after acceptation by all } \\
\text { Parties) and Explanatory Memorandum }\end{array}$ \\
\hline
\end{tabular}




\begin{tabular}{|l|l|}
\hline $\begin{array}{l}\text { Institution or } \\
\text { Government }\end{array}$ & Laws, Regulations, Directives and Guidelines \\
\hline & $\begin{array}{l}\text { Additional Protocol to Convention ETS No. 108 on Supervisory Authorities and } \\
\text { Trans-border Data Flows and Explanatory Report (ETS No. 181, opened for } \\
\text { signature on 8 November 2001) } \\
\text { Recommendation No. R(2002) 9 on the protection of personal data collected } \\
\text { and processed for insurance purposes (18 September 2002) and Explanatory } \\
\text { Memorandum } \\
\text { Recommendation No. R(90) 19 on the protection of personal data used for } \\
\text { payment and other operations (13 September 1990) and Explanatory } \\
\text { Memorandum }\end{array}$ \\
\hline EU-US & Safe Harbor Framework, 2000 \\
\hline US & $\begin{array}{l}\text { Fair Credit Reporting Act, 1970 } \\
\text { Fair and Accurate Credit Transaction Act, 2003 }\end{array}$ \\
\hline
\end{tabular}

Several initiatives are underway to improve credit reporting. The Western Hemisphere Credit and Loan Reporting Initiative (WHCRI) ${ }^{96}$ defines policies and actions for sub-regional integration of credit and loan reporting systems. To date, assessments have been conducted in eight countries in Latin America (Brazil, Chile, Colombia, Costa Rica, Mexico, Peru, Trinidad and Tobago, and Uruguay.) ${ }^{97}$ WHCRI plans eventually to cover all the countries of the Latin America Region. In addition, the IFC (as part of the WBG) has developed the Global Credit Bureau Program, which supports credit bureaus in more than 100 countries worldwide. ${ }^{98}$ The WBG has also established the African Credit Reporting and Financial Information Infrastructure Program to improve the quality and availability of data on borrowers in Africa. A similar program is also envisaged for the Middle East.

In addition, the Credit Reporting Standards Setting Task Force was launched by the World Bank, with support of the BIS, with the objective of defining a core set of international standards for credit reporting. This exercise led to the General Principles for Credit Reporting, published in September 2011, which includes elements of consumer protection as an instrument to facilitate credit reporting systems ${ }^{99}$.

In addition, in June 2008 the European Commission set up an Expert Group on Credit Histories to identify barriers to the access to, and exchange of, credit information within the EU and to make recommendations to the Commission. ${ }^{100}$

The Good Practices in this Annex are based upon international approaches regarding data protection policies. These include the basic principles by the United Nations, Organization for Economic Co-operation and Development, the Asia-Pacific Economic Cooperation, the European Union and the Council of Europe. Alternative regulatory models have been taken into account through the comparison of credit reporting regulations in 100 countries. ${ }^{101}$ Thus, the Good Practices have been developed based upon a broad range of policy and academic literature, crosscountry law evaluation, as well as practical experience from a number of country-based analyses. $^{102}$

The Good Practices focus on the issues of privacy and data protection, which lie at the core of sound consumer protection in credit reporting systems. It is recognized, however, that other issues are also important and should be considered. In particular, credit reporting systems should be subject to appropriate oversight with sufficient enforcement authority. Additional issues include the viability of consumer protection institutions, questions of adequate disclosure to consumers 
and accessibility to credit bureaus, reporting and handling of customer information, dispute resolution mechanisms, consumer awareness and empowerment, and competition among credit bureaus.

\section{A. Privacy and Data Protection}

\section{A.1. Consumer Rights in Credit Reporting}

Laws and regulations should specify basic consumer rights in these respects. These rights should include:

a. The right of the consumer to consent to information-sharing based upon the knowledge of the institution's information-sharing practices.

b. The right to access the credit report of the individual, subject to proper identification of that individual and free of charge (at least once a year).

c. The right to know about adverse action in credit decisions or less-than-optimal conditions/prices due to credit report information. In this process, consumers should be provided with the name and address of the credit bureau.

d. The right to be informed about all inquiries within a period of time, such as six months.

e. The right to correct factually incorrect information or to have it deleted.

f. The right to mark (flag) information that is in dispute.

g. The right to decide if the consumer's credit information (for purposes not related to the granting of credit) can be shared with third parties.

h. The right to have sensitive information especially protected (not included in the credit report), such as race, political and philosophical views, religion, medical information, sexual orientation or trade union membership.

i. The right to reasonable retention periods such as those for positive information (for example, at least two years) and negative information (for example, 5-7 years.)

j. The right to have information kept confidential and with sufficient security measures in place to prevent unauthorized access, misuse of data, or loss or destruction of data.

Informed consent is the necessary pre-condition for creating transparency of information processing. Article 3 of the UN Guidelines regarding files states that "the purpose which a file is to serve and its utilization in terms of that purpose should be specified, legitimate and, when it is established, receive a certain amount of publicity or be brought to the attention of the person concerned." This ensures that all processed personal data is relevant to the purpose stated, there are no secret databases, and no data is used without the consent of the data subject. This right can be waived in the context of sharing information with a public credit register for supervisory purposes. However, the consumer should at least be informed about that type of information sharing and be referred to the articles in law applicable to it.

Throughout the world, this Good Practice for consumer protection is reflected in most data protection laws, such as the EU Data Protection Directive (implemented in the 27 EU Member States and some Latin American countries), many non-European laws, ${ }^{103}$ the COE Convention, as well as in the Openness Principle 12 of the OECD Guidelines on the Protection of Privacy and Transborder Flows of Personal Data.

The right to access personal information, and in this context the credit report and score, is justified by Principle 4 of the UN Guidelines ("interested-person access" that demands proper proof of identity). "Access and correction rights" are provided by all major international data protection instruments (UN, OECD, EU and APEC principles). More advanced credit reporting regimes are implementing the requirement to explain to consumers the credit score (for instance, 
as is done in the US). This can be implemented in a cost-effective way, but should be tailored to the development stage of the industry so that, where the industry has just started to operate, companies are not over-burdened with access requirements. In these cases, a transition period would be warranted.

Access by an individual to his or her information is granted in most countries that have a data protection law.

Access is the pre-condition to dispute resolution and correction. These basic rights are established in all major international instruments relevant for data protection, such as in the UN Guidelines (Principles 2 and 4) and OECD Guidelines on the Protection of Privacy and Transborder Flows of Personal Data (Individual Participation Principle 13). In the latter, it is stated that the individual has the right to obtain confirmation whether information has been stored from the data controller and to have it communicated within a reasonable manner and timeframe. Access is also mentioned in the World Bank's Principles for Effective Insolvency and Creditor/Debtor Regimes (Principle B1.4). ${ }^{104}$ In addition, the cost of correction is to be borne to the data controller (UN Principle 4). According to Jentzsch (2007), the right to have information corrected was laid out in more than 40 countries.

The right to block information in cases of dispute is also common in credit reporting regimes. Between 2005 and 2006, this right was implemented in 25 countries. Blocked or flagged information indicating a dispute is an additional quality signal for creditors. The right to know to whom the information was disclosed was implemented in 44 countries (Jentzsch, 2007).

The consent principle in many cases includes the provision that individuals can stop information processing for purposes unrelated to credit granting, such as marketing. Marketing restrictions (in terms of opt-in or opt-out) were in place in 23 countries. Opt-out increases marketing participation rates and depends on the framing of the question. ${ }^{105}$ For instance, APEC's Principle IV Uses of Personal Information) demands that information is only used for the purposes of collection stated beforehand, except where the individual has given consent.

The right to have sensitive information specifically protected is part of most major international instruments, such as the OECD reports (Comment to Guidelines on the Protection of Privacy), UN Principles (Principle 5), the COE Convention (Article 6), the EU Data Protection Directive (Article 8), and the EU-US Safe Harbor Framework. Legal controls against anti-discrimination are also discussed in the World Bank Principles (Principle 15). Only the APEC Privacy Framework does not demand extra protection of personal sensitive information.

The major international instruments also demand a limitation on information collection and distribution, e.g. OECD Guidelines on the Protection of Privacy and Transborder Flows of Personal Data (Principle 10), UN Principles (Principle 3), APEC Privacy Framework (Principle III Collection Limitation), and the COE Convention. The latter, for instance, states in Article 5 e. that data are "preserved in a form which permits identification of the data subjects for no longer than is required for the purpose for which those data are stored." Companies have an incentive to collect personal information excessively and this can lead to sub-optimal market results. ${ }^{106}$ Therefore, it is good practice to find time limits that set a limitation on data collection.

International averages for negative information are seven years for bankruptcy, five years for lawsuits, and six years for judgments for a sub-sample of the surveyed countries. The World Bank typically proposes a range of five to seven years (Principle 17). According to the above principle 
of purpose specification, positive information should not be stored excessively as it loses its predictive power.

The duty of financial institutions to inform customers in case of adverse action in credit decisions is now part of US and European legislations. According to Jentzsch (2007), only seven countries had this clause (during the time of research in 2005-2006), partly because it was only recently introduced in Europe in the Article 9 of the EU Directive on Credit Agreements for Consumers.

According to the Directive, creditors should inform the consumer immediately and free of charge about the result of database consultation and the particulars of the databases consulted. The additional duty to inform consumers about less than optimal conditions is part of US regulations. ${ }^{107}$ Informing consumers "only in adverse action situations" is not sufficient for adequate data protection.

Also, care should be taken to ensure that public sector and private sector credit registers provide the same level of consumer protection on the use of personal data. Both types of information systems provide data that allow for identification of individuals and both should provide the same high quality of protection for consumers of financial services.

\section{B. Consumer Empowerment \& Financial Literacy}

\section{B.1. Unbiased Information for Consumers}

Financial regulators should provide, via the internet and printed publications, independent information for consumers that seek to improve their knowledge for actively managing the credit report.

Education on credit reporting may comprise several activities, such as the key information brochure that explains to consumers their privacy choices and their impacts, as well as rights and obligations. Some examples from the FTC are the following:

- Privacy Choices for Your Personal Financial Information

- Building a Better Credit Report

- Credit Repair: Self Help May Be Best

- Disposing of Consumer Report Information? New Rule Tells How

It would be important to help consumers understand that credit financing costs could be reduced once the credit score reflects a better credit risk and how this can be achieved. Education on credit reporting should also include a disclosure of the main factors that have an impact on the credit score. Public information campaigns have been actively pursued by regulators in the US, South Africa, and the UK.

\section{B.2. Awareness of Credit Reporting}

In order to ensure that financial consumer protection and educational initiatives are appropriate, it is necessary to measure financial literacy with large-scale surveys that are repeated periodically. These surveys should include questions on credit reporting and scoring.

Credit reporting is becoming an ever more pervasive activity in the economy. Therefore, questions about knowledge regarding credit reporting should be included in financial literacy surveys, in order for public information campaigns on credit reporting to be tailored as best as possible. There is, however, no international precedent for this Good Practice. 


\title{
Annex III: Background
}

\section{Financial Consumer Protection and Global Financial Regulation}

\author{
Global Retail Financial Market Development
}

Until the financial crisis of 2007-09, the global economy was adding an estimated 150 million new consumers of financial services each year. Rates of increase have since slowed but growth continues apace. Most new consumers are in developing countries, where financial consumer protection is still in its infancy. Global consumer debt stood at 12-14 percent of GDP in the first half of the 1990s but it has increased to 18 percent in recent years. Mortgage debt rose still more rapidly-from 46 percent of GDP in 2000 to over 70 percent in 2007. ${ }^{108}$ At the same time, households have become increasingly responsible for funding their own retirement pensions, while expanding their investments in securities, investment funds and insurance policies. In addition, particularly in low-income countries, households have increased their use of payments services and remittances. ${ }^{109}$

By supporting the expansion of financial inclusion, the rise of consumer finance contributes to economic growth. Financial services provide two key functions for all households, namely, risk management and inter-temporal consumption smoothing. By employing such services, consumers are able to "smooth out" consumption in periods of scarcity and thus do not need to consume their productive capital. In addition, financial services allow consumers to borrow funds to invest in new assets, including those of their businesses, however small-scale. Furthermore, the use of formal financial services results in efficiency of financial transactions. ${ }^{110}$ Yet an estimated 2.7 billion working-age adults worldwide lack access to any formal financial services, relying on unreliable and often expensive informal financial service providers. ${ }^{111}$

\section{Consumer Finance and Risk to Financial Stability}

The global financial crisis of 2007-09 highlighted the importance of financial consumer protection for the long-term stability of the financial system and the global economy. Commentators have pointed to a combination of unconstrained financial innovation, excessive levels of global liquidity, and an extended period of accumulating macroeconomic and financial imbalances that supported unsustainable increases in financial leverage and risks. ${ }^{112}$ Contributing to the financial crisis was the rapid growth of household lending over the last decade. ${ }^{113}$ Financial institutions also transferred their financial exposures to households, which increasingly became subject to new types of risks, such as those involved in borrowing in foreign currencies and at variable interest rates. ${ }^{114}$ In developed mortgage markets, complex financial products and services (such as hybrid adjustable-rate mortgages) were sold to borrowers, some of whom had troubled credit histories. In today's deeply interconnected financial markets, the securitization of such household credit spread the weaknesses in household finance to the rest of the global financial system. ${ }^{115}$ Furthermore imperfections in the financial market are likely to have a greater impact on the rest of the economy than weaknesses in other markets due to the financial market's central role in ensuring efficient allocation of capital.

Over the last decade, risk has been exacerbated by the expansion in many low-income and emerging markets of the use of formal financial services. Increased levels of financial 
inclusion have brought new consumers into formal financial markets, which in emerging economies often have weak financial consumer protection. In addition, technology has changed the types of protection needed by many first-time financial consumers. For example, where access to formal banking services is difficult, financial services delivered via cellular/mobile telephones have filled a critical need for consumers. Such delivery, however, raises issues of consumer disclosure and recourse. ${ }^{116}$

At the same time, financial literacy of consumers has not caught up with consumers' expanded use of financial services, especially in low-income markets. The extent of financial literacy significantly lags behind what is required for most consumers to understand the available financial products and services - and what is needed for consumers to be confident that they know what they are buying. In many emerging markets, a significant portion of the public lacks any history of using basic, let alone sophisticated, financial products and services. For many firsttime financial consumers, no member of their circle of friends and extended family has ever entered into a long-term financial contract, such as a home mortgage loan. Furthermore, even basic financial products and services may challenge the ability of inexperienced consumers to understand the inherent risks and rewards involved in using formal financial services.

\section{Financial Consumer Protection, Financial System Development and Risk Mitigation}

Financial consumer protection promotes the efficiency, transparency and deepening of retail financial markets. Consumers who are empowered with information and basic rightsand who are aware of their responsibilities - provide an important source of market discipline to the financial system, encouraging financial institutions to compete by offering useful products and services. In turn, this promotes consumer trust and engagement with the formal financial services market.

Financial consumer protection is needed to ensure that expanded financial inclusion results in equitable growth. Strong consumer protection helps to ensure that increased use of financial services benefits all consumers and does not create undue risk for households. Furthermore, weak financial consumer protection can cause the growth-promoting benefits of expanded access to consumer financial products and services either to be lost or else greatly diminished. ${ }^{117}$ Weak protection undermines consumers' confidence and public trust, thus discouraging households from purchasing financial products and services - and increasing the likelihood that the products and services they purchase fails to meet their needs and objectives.

Consumer protection also improves governance of financial institutions. By strengthening transparency in the delivery of financial services and the accountability of financial institutions, consumer protection helps build demand for good governance and the strengthening of business standards in the financial system.

In addition, consumer protection helps financial institutions face the many risks that arise in dealing with retail customers. In its April 2008 report, the Joint Forum of the Basel Committee on Banking Supervision, the International Organization of Securities Commission and the International Association of Insurance Supervisors identified three potential key risks related to "mis-selling" financial products and services to retail customers. ${ }^{118}$ They are: (1) legal risk, if successful lawsuits from collective action by customers or enforcement actions by supervisory agencies result in obligations to pay financial compensation or fines; (2) short-term liquidity risk and long-term solvency risk, if retail customers are treated unfairly and, thus, shun a financial institution and withdraw their business from it; and (3) contagion risk, if the problems of one 
financial institution (or type of financial product) spread across the financial system. ${ }^{119}$ Effective consumer protection can help ensure that the actions of financial firms do not make them subject to criticisms of mis-selling. Specifically in the microfinance sector, minimum consumer protection regulation is needed to avoid the reputational risk that arises when borrowers become over-indebted. ${ }^{120}$

Last but not least, consumer protection protects the financial system from the risk of government over-reaction. The impact of too little consumer protection became evident during the insurance and superannuation scandals in the United Kingdom and Australia respectively, resulting in extensive studies on recommendations for regulatory reform, including consumer disclosure. ${ }^{121}$ The political response to a collapse of a part of the financial system may be to overcompensate with heavy regulation. As a reaction to increasing public pressure to adopt consumer protection measures, some governments have resorted to imposing interest rate caps for consumer loans, thus undermining development of credit markets. While the issues of mis-selling are particularly important in high-income and middle-income countries, they also apply to lowincome countries. For example, in India and Nicaragua mis-selling of microcredit has resulted in government regulation restricting the ability of lenders to collect repayments. ${ }^{122}$

\section{Designing Financial Consumer Protection Programs}

\section{Key Elements}

The focus of financial consumer protection is on the relationship and interaction between a retail customer and a financial institution. When designing successful consumer protection, it is important to distinguish between unsophisticated retail (and possibly even illiterate) consumers versus highly sophisticated corporate customers. Transactions between corporate customers and financial institutions are not subject to many of the problems that can potentially harm households and individuals. Thus it is the retail market for financial services (sometimes called the businessto-consumer or "B2C" market) that is the focus of financial consumer protection.

At its heart, the need for financial consumer protection arises from an imbalance of power, information and resources between consumers and their financial service providers, placing consumers at a disadvantage. Financial institutions know their products well but individual retail consumers find it difficult and costly to obtain sufficient information regarding their financial purchases. ${ }^{123}$ In addition, financial products and services tend to be difficult to understand, compounded by increasing complexity and sophistication in recent years. Also consumers typically find it expensive and problematic to launch lawsuits to sue firms to enforce the terms of individual contracts.

The imbalance of power between consumers and providers is particularly marked in financial markets. In part, this is due to the complex nature of financial products and services which often have a deferred expected pay-off to the consumer and, in many cases, are purchased only rarely. Residential mortgages are a good example. Most consumers enter into a home mortgage just a few times in their lifetimes, if at all. This makes it hard for consumers to learn from their mistakes and become financially literate, at least with respect to collateral on their immoveable property. It also makes it easy for a bank or other financial firm to profit from deceptive or poor quality products, knowing that much time will likely pass before the consumer learns the truth. Also, decisions about financial products and services involve assessments of risk and estimates of future values that are complex even for sophisticated retail consumers. Even in 
well-developed markets, weak financial consumer protection can render households vulnerable to unfair and abusive practices of financial institutions, including financial frauds and scams. Consumers may also experience inadequate disclosure of the risks involved in taking on large debts, particularly in foreign currency.

\section{An efficient and well-regulated financial system should provide consumers with five key elements:}

(1) Transparency, by providing full, plain, adequate and comparable (and understandable) information about the prices, terms and conditions (and inherent risks) of financial products and services;

(2) Choice, by ensuring fair, non-coercive and reasonable practices in the selling and advertising of financial products and services, and collection of payments;

(3) Redress, by providing inexpensive and speedy mechanisms to address complaints and resolve disputes;

(4) Privacy, by ensuring protection over third-party access to personal financial information; and

(5) Trust, by ensuring that financial firms act professionally and deliver what they promise.

Financial consumer protection is delivered in two ways: (1) financial regulation and (2) financial education. Such financial regulation consists of market conduct regulation, i.e. laws and regulations regarding the business conduct of financial institutions in delivering financial products and services to consumers. Business conduct regulation includes government regulation, i.e. laws and regulations issued by government agencies such as financial supervisors and consumer protection agencies. It also includes self-regulation, that is, the voluntary codes of conduct and other responsible finance practices adopted by industry associations as a means of encouraging improved business practices by financial institutions. Financial education consists of programs of financial literacy to help consumers understand the risks and rewards, as well as their rights and obligations, in using financial products and services.

\section{Financial Regulation}

Some regulation of financial markets is needed. As stated by Dani Rodrik (2007), "Markets will not work on their own. You need all the institutions that regulate markets, stabilize markets ... compensate losers and provide the safety nets, without which markets can neither be legitimate (n)or, for that matter, efficient ...." ${ }^{124}$ Furthermore, financial consumer protection can help markets work more effectively since risks are less likely to be misallocated, and financial institutions are more likely to act carefully, than they would in the absence of strong regulations for financial consumer protection.

Competition policy will not fully address consumer protection issues on its own. Mark Armstrong (2008) observes that in most competitive markets, competition policies are sufficient to ensure that firms succeed by providing consumers with the products and services they want. However, Armstrong argues that retail financial markets are different from other markets and more is required to ensure their efficiency. He notes that, in financial markets, government policies are needed to ensure that: (1) comparable information is provided to consumers, (2) consumers become aware of market conditions, (3) consumer search costs are reduced and (4) hidden costs are clarified. Where such policies are in place, consumers can access essential information on which to make informed decisions. ${ }^{125}$ This is an important first step. However, building trust in the financial system requires still more, including policies to prevent misleading and fraudulent marketing. ${ }^{126}$ 
The challenge is to strike the right balance between government regulation and the forces of market competition. Government intervention should be considered when it is both feasible and cost-effective-and when there is inadequate capacity for self-regulation. Rules need to be proactive to prevent abuses and not simply react to problems of the past. In particular, this requires that violations of regulations are sufficiently punished with the aim at least of deterring future infringements. At the same time, undue regulation can stifle financial innovation. As noted by US Federal Reserve Board Chairman Ben Bernanke in April 2009, regulators should "strive for the highest standards of consumer protection without eliminating the beneficial effects of responsible innovation on consumer choice and access to credit." ${ }^{127}$ Where resources are available, the costs and benefits of the proposed financial consumer protection reforms should be analyzed, taking into account the estimated direct and indirect effect on competition, innovation and growth. Such analysis will help ensure that the proposed regulation is both effective and efficient.

\begin{abstract}
Although self-regulation can be useful in improving the business practices of financial institutions, it can never be a substitute for government regulation to protect consumers. Regulation by financial institutions, or what is known as "self-regulation," occurs when institutions agree among themselves first to establish voluntary codes for the business conduct of their dealings with consumers, and then to review the extent to which the institutions follow the requirements of the codes. Codes of conduct can encourage financial institutions to follow ethical standards in the treatment of retail customers. The codes are generally developed and implemented by industry associations. Market conduct codes primarily act to complement financial regulation, particularly if the regulator (or supervisor) oversees the codes and reports on their effectiveness. However, particularly in developing countries, self-regulation is frequently ineffective since institutional capacities of industry associations are often limited and financial markets are highly concentrated and dominated by a small number of institutions. If the voluntary codes are not sufficient to improve business practices, the government may wish to consider enacting legislation inspired by elements of the codes in order to strengthen the legal framework for financial services and then ensure that the laws and regulations are effectively applied and enforced.
\end{abstract}

In the long-run, prudential regulation and consumer protection regulation complement each other. The rationale for financial regulation ultimately rests on the objectives of mitigating systemic risk and protecting consumers, including retail investors. In most circumstances, the two objectives are complementary. For example, deposit insurance schemes can reduce systemic risk while protecting retail deposits. In some instances, however, the objectives may be in conflict. For example, by requiring high levels of bank capital, measures to protect depositors may reduce the availability of credit for the economy or reduce market liquidity and, thus, contribute to macro-systemic risk. ${ }^{128}$ However, over the long-term, prudential and business conduct supervision are complementary. Ensuring that consumers have minimum legal protections and access to financial education will strengthen the quality of the retail portfolios of financial institutions and thereby strengthen the stability of the financial system.

Furthermore, business conduct supervision is needed where prudential supervision is not applicable. The last decade has seen a rapid expansion in the role of financial intermediaries. They are diverse and their roles range from payment agents for banking to mortgage brokers for residential mortgage underwriting. Such intermediaries create risk for the financial system, but they cannot be supervised using prudential oversight. Such financial intermediaries should be subject to business conduct (i.e. consumer protection) regulation and supervision. ${ }^{129}$ 
The design of financial consumer protection measures should also take into account recent research in behavioral economics. Behavioral economics can help frame policies. It can also help de-bias presentation of consumer information that empowers consumers in their decisionmaking (such as information regarding minimum payments). Psychological biases, including mistaken beliefs, may influence consumers to make choices that are neither rational nor optimal. Consumers, for example, may assume that interest rate charges or penalties will not apply to them or they may be over-optimistic about their financial futures and, thus, unable to forecast their future financial status accurately. ${ }^{130}$ Individuals often over-estimate their financial capabilities, including their understanding of the concept of the time value of money and the impact of compound interest over time. ${ }^{131}$ Consumers also fall victim to projection bias, namely the prediction of personal preferences into the future. ${ }^{132}$ Other related problems are hyperbolic discounting (where consumers apply a high discount rate to their future income and, thus, reduce the present value of their savings to an unreasonably low level), impulse purchasing and weaknesses in self-control. The research points to the need for surveys of financial literacy and consumer spending habits as essential background for designing consumer information policies-as well as programs of financial education.

\section{Financial Education}

Financial literacy is an important part of financial consumer protection. Financial education cannot substitute for consumer protection regulation. However, financial education and consumer protection regulation are complementary and should be combined in a program of reform of financial consumer protection. ${ }^{133}$ It is not practical to consider measures to improve financial consumer protection without also looking for ways of strengthening financial literacy. A welleducated consumer should be able to understand consumer disclosures, the risks and rewards, and the legal rights and obligations that are involved. In short, a financially literate consumer should be able to make informed decisions about financial products and services. ${ }^{134}$ Such empowered consumers should play an active role in shopping for the best financial products and servicesand the best providers - that meet their needs. However, financial education is not a panacea. Even the best programs of financial education cannot replace basic, well-tested and high-impact rules of business conduct for financial institutions, such as adequate disclosure of effective interest rates.

Financial education for consumers should focus on the appropriate use of financial products and services. Particularly complex financial products and services, such as long-term residential mortgages with adjustable rates of interest, require more in-depth understanding than simple products such as bank savings accounts. Financial education programs should be adjusted accordingly. It may also be helpful to identify specific target groups for financial education, in particular those most fragile and vulnerable, including the unemployed and migrants and those exposed to accidents of life which weaken their financial situation, such as a sudden drop of income, divorce or a loss in the family. For such populations, financial education should include discussion of the risks related to episodic expense and revenue streams and the potential for overindebtedness.

General financial education is important but lies outside the scope of targeted programs of financial consumer protection. General programs of financial education should teach households how to prepare family budgets and plans to meet their financial needs and goals. These skills are critically important in establishing and maintaining financial well-being. They 
should be complementary to (but not directly part of) targeted financial consumer protection initiatives. ${ }^{135}$

Building financial literacy requires a sustained long-term effort. While the experience of industrialized countries over the last thirty years - and more recently in developing countrieshas identified lessons of "what works and what does not" in consumer protection, little is clearly understood as to what works (and what does not) in improving financial literacy over the longterm, although ongoing research is expected to provide new insights. ${ }^{136}$ Box 1 summarizes some initial measures that have pointed to success being realized in financial education programs. ${ }^{137}$

\section{Box 1: Measures to Ensure Success of Financial Education Programs}

National financial education programs should be led by the financial regulators but involve all stakeholders. It is the financial regulators who are most aware of the weaknesses in financial literacyand the issues that these weaknesses create for financial sector development. However, national programs need the active involvement of all stakeholders, including the financial services industry and their professional associations, consumer advocacy organizations, government ministries and agencies (and particularly the education ministry) as well as the mass media.

Experience in developed countries suggests that financial education should be focused on "teachable moments." To be successful, financial education needs to provide information "at the time the consumer wants it and in the form the consumer wants it." Consumers are often receptive to financial education at certain points in their lives, for example, when they first take a residential mortgage, start a family, or plan for retirement.

Financial education should be tailored to consumers' levels of literacy and expertise. Particularly in low-income countries, financial education programs need to be tailored to meet the needs of consumers with low levels of general literacy and limited experience in using financial services.

Any program to improve financial education should be rigorously tested. Techniques of delivering financial education have been well tested in the US, Europe and elsewhere over the last 30 years, but their impact on levels of financial literacy is still unclear. Even more unclear is the impact of financial education on consumer behavior. Financial education should, therefore, be encouraged, but it should be rigorously tested and evaluated in the short and long-term.

National financial education strategies should include a role for both government and civil society. Clear guidelines are also needed on the types of information and personnel resources that should be provided by financial service providers, government and consumer organizations. The industry associations within the financial system, such as banking associations, are often keenly interested in providing financial education and training for consumers. This should be encouraged as part of a national strategy to improve financial education. Consideration should also be given to ways of strengthening consumer organizations and ensuring that they have a long-term and stable funding source that will allow them to play a vital role in protecting and educating financial consumers.

\section{Design of the Good Practices for Financial Consumer Protection}

The Good Practices attempt to capture what are generally agreed to be effective approaches to treating financial consumer protection. They seek to state measures that evoke general agreement among regulators. As a result, where substantial debate still remains over the best way(s) of dealing with an issue related to financial consumer protection, that issue has not been 
included. For example, there are wide-ranging views on the best institutional structure for financial regulation, including regulation of business conduct. Nier (2009) provides preliminary analysis showing that countries with separate consumer protection and prudential regulators (known as the "Twin Peak" approach) generally weather financial crises better than those with a single integrated regulatory agency with both prudential and consumer protection mandates. ${ }^{138}$ However, differing views are provided by the Group of 30 and the FSA's Turner Review. ${ }^{139}$ Thus, the subject remains one for further debate. The Good Practices also do not include issues of approval of product design - either before or after a financial product is issued. Some regulators prohibit financial products and services that they consider to be "toxic" for financial consumers, but there exists no international consensus on the parameters for any such financial product approval or prohibition.

The Good Practices relate only to the direct relationships between retail customers and financial institutions (or their agents and intermediaries). Thus, the Good Practices do not include collateral registries. Although they are important parts of financial system infrastructure, collateral registries are not directly involved in relations between consumers and their financial institutions. Small firms, especially sole proprietorships, are also not specifically covered under the Good Practices but the recommendations for consumer protection will generally also help to protect small businesses. However, microfinance borrowers are covered (as part of the Good Practices for Non-Bank Credit Institutions) due to the difficulty in separating loans for micro businesses from credits for consumers.

The Good Practices cover only the formal financial system. Although the Good Practices apply to various forms of regulated non-bank financial institutions (such as microfinance lenders, credit cooperatives, credit unions and investment clubs), informal service providers, such as "loan sharks," lie beyond the scope of the Good Practices. At the same time, any entity that engaged in selling financial products or services should be subject to appropriate regulation. If not, consumers may be vulnerable to entities offering financial products or services using business models that are specifically designed to take advantage of regulatory gaps.

Good Practices for key parts of the financial system have been prepared. Detailed Good Practices for each major sector-banking, securities, insurance, and non-bank credit institutions - are presented with annotations to identify the basis for each Good Practice. ${ }^{140}$ One of the challenges has been to choose between a common set of Good Practices for all consumer finance and Good Practices that are sector-specific. The Good Practices are broken down by sector since most laws and regulatory agencies are specific to different types of financial institutions. Such an approach also facilitates the work of assessors who are generally specialists in one or two sectors. Consideration could also, however, be given to product or service-specific Good Practices. Certainly many common elements are present in all types of retail financial products and services and the approach and general objectives are similar regardless of the specific retail product or service. However, each sector of the financial market has its own peculiarities and a common approach misses important subtleties. However consumer protection is a systemic issue across the financial sector. As a result, effective market conduct supervision requires close cooperation among government agencies to align with the interconnected financial markets they must supervise. The Good Practices have been designed with this approach in mind.

An increasingly important issue for consumer protection regimes is "regulatory arbitrage." In such cases, regulators may miss important business conduct issues regarding financial products and services that look like one type of product but are legally another. Unit-linked insurance policies (also called variable annuities) are a case in point. From a legal perspective, they are insurance products and are therefore regulated under the rules that apply to insurance policies. 
However, from a functional perspective, they are indistinguishable from investment funds. Yet such unit-linked products are generally regulated as insurance products and are not subject to the stringent disclosure requirements that typically apply to investment funds. Similar issues arise for mortgages and mortgage alternatives, such as building savings loans or specific consumer credit related to home building or renovation. A cross-sector approach is likely to become increasingly significant as more sophisticated financial products and services become available and consumer well-being ever more threatened by regulatory arbitrage in packaging products.

The Good Practices allow a country to compare its financial consumer protection framework to international practice. The Good Practices provide an effective tool for systematic analysis of the laws, regulations and institutions involved in financial consumer protection, as well as allow detailed comparisons across different countries. The Good Practices thus provide the basis for countries to conduct self-assessments of their financial consumer protection frameworks. By providing a level of detail not generally found in overarching "principles", the Good Practices afford a precise and systematic methodology for assessing a country's consumer protection framework compared to international practice-and, thus, for determining what needs to be done. However, the value of the Good Practices is in generating specific advice not only for government authorities but also for financial industry institutions and associations, as well as consumer organizations. It is then up to the authorities, institutions and organizations in each country to determine the pace and strategic choices to complete a road-map of reform implementation, with the details of implementation dependent entirely on the country context. In three out of the 18 countries noted in Table 1, the diagnostic reviews have led to the development of detailed country-level action plans and implementation programs for strengthening legislative and institutional capacity. All of the diagnostics have stimulated substantive changes to government policies, national laws or institutional structures.

However, implementation of the Good Practices should be tailored to a country's needs and objectives. While the work of carrying through on appropriate reforms is necessarily countrycontext specific, the basic ideas are fundamental and universally applicable. They should, therefore, be part of consumer protection strategies for countries worldwide. In some low-income countries, such as those of sub-Sahara Africa, the regulated financial system serves less than 20 percent of the population and the rest are obliged to rely on informal financial service providers that fall outside government regulation. In countries where formal financial services are not widely used, consumer protection regulation and supervision should be designed in ways that increase access to financial services and strengthen consumer trust in the formal financial system. Furthermore, it is well-recognized that no recommendations coming from an outside source can be implemented without local "champions" pursuing programs that meet the country's needs and objectives. Also country action plans need to take into account the political strength and will of these champions. In most countries, the best solution is likely to be a phased-in reform program. CGAP suggests, for example, that in countries with low supervisory capacity, such phasing-in should be based on: (1) identification of key issues and (2) assessment of government's capacity to develop rules, investigate and detect alleged breaches of the rules, and sanction financial institutions found to have broken the rules. ${ }^{141}$ It would also be helpful to prepare even rough estimates of the expected impact of reforms on the affordability and availability of financial services. 


\section{Possible Areas for Future Work by the International Community}

The Good Practices should inevitably be further refined and developed. Future work might include refinement of the Good Practices for private pensions and credit reporting (in addition to future revisions of the other Good Practices.) Good Practices are also needed for residential mortgage underwriting. It may be helpful to expand the discussion of consumer protection for credit cards to debit cards and prepaid cards. In particular, specific issues on prepaid cards and mobile money products related to procedures for closing accounts and forfeiture of unused balances. In addition, future revisions of the Good Practices will benefit from comments received on the existing drafts, as well as from examples of successful approaches in low-income economies or other countries where resources for financial system supervision are especially limited. Consideration could also be given to increasing the consistency of the Good Practices across the different types of financial services, and clarifying the reasons for the differences among different services. The Good Practices will also benefit from the results of ongoing international work, including that of FinCoNet, the International Network on Financial Education, the OECD Task Force on Financial Consumer Protection and the World Bank-led task force on consumer insolvency. At the same time, there is an active ongoing debate--particularly in the US and EU--about the future of financial regulation and supervision (including that for market conduct, i.e. consumer protection). The final resolution of the debate on financial regulation and supervision will substantially influence future revisions of the Good Practices.

New research is also emerging on key consumer protection issues. Examples include the finding that the structure for remuneration for those selling both insurance and securities products has a strong influence in determining which products are sold to consumers. A future Good Practice might suggest that financial advisers be paid on a fee (rather than commission) basis. ${ }^{142}$

Needed also are supporting papers focused on the specific needs of low-income countries. Particularly in low-income countries, it would be useful to look at measures that increase the depth of services for under-served households. This might include, for example, giving all consumers the right to a minimum-service bank account, although analysis should be made of the likely impact of any such legal stipulation. Also important would be an analysis of the rapid development of bank assurance (sometimes called the "bank insurance model") in almost all emerging markets. For low-income countries, future work might also include an analysis of the use of customary law in alternative redress mechanisms, such as oral dispute resolution.

Consideration should be given to ways of expanding the role of civil society. Self-regulatory organizations (such as industry associations) should be active in consumer protection and financial education. Measures should also be developed to ensure that consumer advocacy organizations and other non-government organizations (NGOs) are effective participants in programs to strengthen financial consumer protection - and that they have access to stable sources of funding for their ongoing operations. For countries with programs in financial consumer protection, technical assistance and training should be provided by the international community, including through civil society.

Developing indicators for measuring the levels of financial consumer protection across countries would be useful. As a snapshot of a country's financial consumer protection framework, indicators summarizing the level of development of the legal, regulatory and institutional framework for financial consumer protection would be useful as a form of crosscountry analysis. In addition to analysis of legislation and institutional structures, it may also be 
helpful to incorporate the findings of national surveys of financial literacy and consumer behavior, as well as levels and types of complaints regarding consumer financial services.

The Developing tools to help regulators define priorities for choosing among the recommendations would be useful. National governments are often well-equipped to identify weak points and define what changes are needed to improve the financial consumer environment. However, all governments have limited resources. Tools are, therefore, needed to assist governments in selecting the reforms with the best potential for positive impact. Such tools should include analyses of risk and impact assessments, as well as estimates of the cost of compliance for financial service firms, so as to help reasonably predict the expected nature and timing of changes in the financial system. The tools might also provide guidance to countries in preparing self-assessments of their financial consumer protection frameworks.

The tools should also include rigorous testing and measurement of the impact of financial consumer protection measures. Household surveys of financial literacy and consumer behavior provide a useful baseline assessment against which the impact and effectiveness of financial consumer protection reform programs can be measured. Importantly, one of the objectives of the surveys should be to ask about consumer confidence in the use of formal financial services. However, the extent of consumer understanding of the information for financial products and services should also be assessed, using consumer cognitive and usability testing--and the findings should be used to inform the design of consumer disclosures. ${ }^{143}$ In the US, the Federal Reserve Board has conducted extensive testing of mandatory disclosure of credit card information prior to the release of detailed regulations on disclosure. It would be useful to conduct similar testing in other countries, including in low-income economies and in those with low levels of financial literacy. In addition to household surveys and mystery shopping, it may be useful to consider other quantitative and qualitative evaluation techniques, including ethnographic research tools. Experimentation of different approaches, including delivery of financial education through private sector financial institutions and via mass media, would also be helpful. ${ }^{144}$ However, the impact of using experimental methods to provide financial education should be measured and evaluated, including, where possible, through randomized controlled trials. Also, consumer research and testing of the ultimate impact of reforms with different products and services would be particularly useful. Innovation may lead to new approaches in the delivery of financial services, particularly in low-income countries, and research would help to identify the benefits and risks for consumers in using new financial products and services. 


\section{Notes}

${ }^{1}$ Consumer protection regulation/supervision is often also called "market conduct" regulation/supervision or "business conduct" regulation/supervision.

${ }^{2}$ G20 Communiqué: Meeting of the Finance Ministers and Central Bank Governors, Paris, 18-19 February 2011, available at http://www.g20.org/Documents2011/02/COMMUNIQUE-G20_MGM\%20_1819 February 2011.pdf

${ }^{3}$ The Group of Twenty (G20) Finance Ministers and Central Bank Governors was established in 1999 to bring together systemically important industrialized and developing economies to discuss key issues in the global economy. The G20 consists of the Ministers of Finance and Central Bank Governors of 19 countries, namely: Argentina, Australia, Brazil, Canada, China, France, Germany, India, Indonesia, Italy, Japan, Mexico, Russia, Saudi Arabia, South Africa, Republic of Korea, Turkey, United Kingdom and United States of America, as well as the European Union, represented by the rotating Council presidency and the European Central Bank. The World Bank participated in both the OECD and FSB consultative advisory groups in preparation on the G20 High Level Principles and the FSB report on consumer finance protection.

${ }^{4}$ See http://www.oecd.org/dataoecd/58/26/48892010.pdf

${ }^{5}$ At the September 2009 G20 summit, leaders noted the need to strengthen the international financial regulatory system: "Far more needs to be done to protect consumers, depositors, and investors against abusive market practices, promote high quality standards, and help ensure the world does not face a crisis of the scope we have seen. We are committed to take action at the national and international level to raise standards together so that our national authorities implement global standards consistently in a way that ensures a level playing field and avoids fragmentation of markets, protectionism, and regulatory arbitrage." (G20 Leaders' Statement: the Pittsburgh USA Summit, September 24-25, 2009.) In November 2010, the G20 summit "asked the FSB (Financial Stability Board) to work in collaboration with the OECD and other international organizations to explore, and report back by the next summit on, options to advance consumer finance protection through informed choice that includes disclosure, transparency and education; protection from fraud, abuse and errors; and recourse and advocacy." (G20 Seoul, Republic of Korea, Summit Leaders' Declaration, November 11-12, 2010.) For further information, see http://www.g20.org/pub communiques.aspx

${ }_{7}^{6}$ See http://www.financialstabilityboard.org/publications/r_111026a.pdf

${ }^{7}$ The section on References provides a partial listing of the OECD's reports, official instruments, and policy proposals related to financial education and financial consumer protection. See also http://www.oecd.org/department/0,3355,en_2649_15251491_1_1_1_1_1,00.html for a discussion of OECD's workshops and papers on financial education and consumer protection.

${ }^{8}$ See Grifoni and Messy (2012) available at http://dx.doi.org/10.1787/5k9bcwct7xmn-en

${ }^{9}$ See http://ec.europa.eu/consumers/rights/fin_serv en.htm

${ }^{10} \mathrm{See}$ https://eiopa.europa.eu/en/newsletters/news-alerts/eiopa-launches-consultation-on-guidelines-oncomplaints-handling-by-insurance-undertakings/index.html

${ }^{11}$ See for example projects in the Caribbean (http://www.iadb.org/en/projects/project,1303.html?id=RGM1062), Ecuador (http://www.iadb.org/en/projects/project,1303.html?id=EC-M1049), Guatemala

(http://www.iadb.org/en/projects/project,1303.html?id=GU-M1034) and Honduras

(http://www.iadb.org/en/projects/project,1303.html?id=HO-M1027)

${ }^{12}$ Technically speaking, financial literacy refers to skills related to using consumer finance while financial capability covers not only skills but also attitudes and behavior. However in common use, the terms are used interchangeably. This is also the approach used in this report.

${ }^{13}$ See

http://www.ifc.org/ifcext/gfm.nsf/AttachmentsByTitle/Responsible+Finance+Report/\$FILE/ResponsibleFi nanceReport.pdf

${ }^{14}$ See http://www.afi-global.org/sites/default/files/mayadeclaration_30sep2011.pdf?op=Download

${ }^{15}$ See Consumers International, Safe, fair and competitive markets in financial services: recommendations for the G20 on the enhancement of consumer protection in financial services, March 2011, available at www.consumersinternational.org/media/669348/cifinancialreport2011.pdf 
16 ISO/COPOLCO discussed standardization of consumer information on financial services, mobile financial service provision and international remittances at its plenary meeting in May 2012. See http://www.iso.org/sites/eNewsletters/COPOLCO/ISO-COPOLCO_enews_010.html

${ }^{17}$ See http://www.financial-education.org

${ }^{18}$ Consumers International, Financial education counselling - Counsellor's handbook, January 2012, available at http://www.consumersinternational.org/news-and-media/publications/financial-educationcounselling-counsellor $\% 27 \mathrm{~s}$-handbook

19 See http://web.worldbank.org/WBSITE/EXTERNAL/TOPICS/EXTSOCIALPROTECTION/0,,contentMDK:2 2079158 menuPK:6963602 pagePK:210058 piPK:210062 theSitePK:282637,00.html

${ }^{20}$ The diagnostic reviews, household survey reports, action plans, as well as materials from dissemination seminars, can be found at http://www.worldbank.org/consumerprotection

${ }^{21}$ The 18 countries comprised Armenia, Azerbaijan, Bosnia and Herzegovina, Bulgaria, Croatia, Czech Republic, Kazakhstan, Latvia, Lithuania, Malawi, Mozambique, Nicaragua, Romania, the Russian Federation, Slovakia, South Africa, Tajikistan and Ukraine.

${ }^{22}$ See Demirguc-Kunt and Klapper (2012) on the Global Financial Inclusion Database (Global Findex) available at http://wwwwds.worldbank.org/servlet/WDSContentServer/WDSP/IB/2012/04/19/000158349 20120419083611/Rend ered/PDF/WPS6025.pdf

${ }^{23}$ See Annex II on Credit Reporting.

${ }^{24}$ The Development Economics Group has conducted research on financial education available at http://econ.worldbank.orgThe Human Development Department is responsible for administering a $\$ 15$ million Financial Literacy and Financial Education Trust Fund from the Russian Federation. From the Fund, $\$ 3.2$ million is administered by the OECD. The Trust Fund finances two areas of development: (1) an instrument to measure levels of financial literacy in low-income settings and populations and (2) a methodology to evaluate results from financial education and capability programs in these settings. In addition, the World Bank has provided a \$25 million loan to the Russian Federation for Financial Literacy and Financial Education. Additional information can be found at

http://www.worldbank.org/consumerprotection Regular reports on the WBG activity are found at http://www/worldbank.org/consumerprotection

${ }^{25}$ For CGAP resources regarding microfinance, see http://www.cgap.org/p/site/c/about/ CGAP has published consumer protection reports on six countries as well as policy notes on consumer protection. See http://www.cgap.org/p/site/c/template.rc/1.11.6053/ In collaboration with ACCION International, CGAP has developed the Smart Campaign for client protection in microfinance, which includes a set of principles as well as programs for certification and self-assessments by microfinance institutions. See http://www.smartcampaign.org/ In addition, in 2011 CGAP prepared a White Paper on Global StandardSetting Bodies and Financial Inclusion for the Poor for the G20 Global Partnership on Financial Inclusion. See http://www.cgap.org/gm/document1.9.55147/CGAP_WhitePaper_Global_Standard_Setting_Bodies.pdf

${ }^{26}$ See Rutledge, Annamalai, Lester and Symonds (2010) http://siteresources.worldbank.org/INTECAREGTOPPRVSECDEV/Resources/GoodPractices_August201 $0 . \mathrm{pdf}$

${ }^{27}$ See for instance--International standards and Good Practices- Basel Core Principles, BIS Supervisory Guidance on Dealing with Weak Banks, BIS Core Principles for Effective Deposit Insurance Systems, BIS Enhancing corporate governance for banking organizations, World Bank General Principles for International Remittance Services, World Bank General Principles for Credit Reporting, IMF--An Overview of the Legal, Institutional, and Regulatory Framework for Bank Insolvency.

${ }^{28}$ See also the OECD Forum, Balancing Globalization, May 22-23, 2006 in Paris and the International Forum on Financial Consumer Protection and Education.

${ }^{29}$ For examples of codes of banking practices, see: https://www.fnb.co.za/legallinks/legal/cobp.html and http://www.bankers.asn.au/Default.aspx?ArticleID=446

${ }^{30}$ For an overview see: http://ec.europa.eu/consumers/cons_org/associations/index_en.htm

${ }^{31}$ Basel Core Principle 18: Abuse of financial services. Supervisors must be satisfied that banks have adequate policies and processes in place, including strict "know-your-customer" rules that promote high 
ethical and professional standards in the financial system and prevent the bank from being used, intentionally or unintentionally, for criminal activities.

${ }^{32}$ See http://www.fatf-gafi.org/document/28/0,3343,en 32250379 $32236930 \quad 33658140 \quad 1 \quad 1 \quad 1 \quad 1,00 . h t m l$ and http://www.fatf-gafi.org/document/9/0,3343,en_32250379_32236920_34032073_1_1_1_1,00.html

${ }^{33}$ See FSA's Money Advice Service website:

http://www.moneyadviceservice.org.uk/yourmoney/

${ }_{34}$ Available at: http://ec.europa.eu/consumers/cons_int/fina_serv/cons_directive/cons_cred1a_en.pdf

${ }^{35}$ See Centre for European Policy Studies and Van Dijk Management Consultants, Tying and other potentially unfair commercial practices in the retail financial service sector, available at

http://ec.europa.eu/internal_market/consultations/docs/2010/tying/report_en.pdf

${ }^{36} \mathrm{See} \mathrm{http://www.fdic.gov/regulations/laws/rules/6500-1360.html \# fdic6500appendixgtopart226new}$

${ }^{37}$ See Regulation No. 1765-2005, as amended in January 2010, available at http://www.sbs.gob.pe

${ }^{38}$ See the Bank of Ghana's Borrowers and Lenders Act, Act No. 773 of 2008. Available at http://www.bog.gov.gh/privatecontent/IDPS/banking\%20and\%20financial\%20laws\%20of\%20ghana\%202 $006 \% 20-\% 202008 . p d f$

${ }^{39}$ About $25 \%$ of South Africans speak isiZulu, $18 \%$ speak isiXhosa and $13 \%$ speak Afrikaans.

${ }^{40}$ See details at http://www.federalreserve.gov/newsevents/press/bcreg/20070523a.htm

${ }^{41}$ Available at https://www.fnb.co.za/downloads/legal/COBP071105.pdf

http://www.bankers.asn.au/Default.aspx?ArticleID=446 and

https://www.fnb.co.za/legallinks/legal/cobp.html

${ }^{42}$ See World Bank Group, Financial and Private Sector Development Vice Presidency, Payment Systems Development Group, Payment Systems Worldwide: a Snapshot. Outcomes of the Global Payment Systems Survey 2008, 2008.

${ }^{43}$ See http://www.bis.org/press/p070123.htm

${ }^{44}$ See http://www.bis.org/publ/cpss101.htm

${ }^{45}$ See http://www.bis.org/press/p060109a.htm

${ }^{46}$ See

http://web.worldbank.org/WBSITE/EXTERNAL/TOPICS/EXTFINANCIALSECTOR/0,,contentMDK:23 196436 pagePK:148956 piPK:216618 theSitePK:282885,00.html

${ }^{47}$ Especially measures by United States- Credit Card Act of 2009 and Regulation Z (Truth in Lending).

${ }^{48}$ For a global overview of practices related to debt collections, see Global Practices in Responsible and Ethical Collections, IFC Working Paper, August 2009.

http://smartlessons.ifc.org/uploads/documents/IFC\%20Ethical\%20collections\%20-

\%20White\%20paper_Final.pdf

${ }^{49}$ In some countries, individual bankruptcy may be referred to as "insolvency".

${ }^{50}$ See World Bank, Report on the Treatment of Insolvency of Natural Persons, Working Group on the Treatment of the Insolvency of Natural Persons (forthcoming) and Susan Block-Lieb, Best Practices in the Insolvency of Natural Persons, The World Bank Insolvency and Creditor/Debtor Regimes Task Force Meetings, Rapporteur's Synopsis, January 2011 Available at http://siteresources.worldbank.org/EXTGILD/Resources/WB_TF_2011_Consumer_Insolvency.pdf

${ }^{51} \mathrm{See}$ http://www.apec.org/apec/documents_reports/finance_ministers_process/2004.html

${ }^{52}$ See OECD, Improving Financial Literacy: Analysis of Issues and Policies, September 2005.

${ }^{53}$ See European Commission, Communication on Financial Education, 2007

${ }^{54}$ This definition, as amended here slightly, is used on the website of the UK Financial Services Authority.

${ }^{55}$ See Shaun Mundy, Financial Education in Schools: Analysis of Selected Current Programmes and Literature - Draft Recommendations for Good Practices, published in proceedings of OECD-US Treasury International Conference on Financial Education, Washington DC, 7-8 May 2008, Volume II.

${ }^{56}$ See http://www.moneymadeclear.fsa.gov.uk

${ }^{57}$ See http://www.moneymadeclear.fsa.gov.uk/publications

${ }^{58}$ See http://www.moneymadeclear.fsa.gov.uk/tools/compare_products.html

${ }^{59} \mathrm{See}$ http://remittanceprices.worldbank.org and http://sendmoneyafrica.worldbank.org maintained by the World Bank. See also http://148.245.102.209/enviacentroamerica (covering Central America) as well as national databases of Australia/New Zealand, Italy and Norway.

${ }^{60}$ See European Commission, Directorate-General for Competition, Report on the retail banking sector inquiry, Commission Staff Working Document, SEC(2007) 106, 31 January 2007. 
${ }^{61}$ The term security as used in this section includes derivatives on securities, including securities linked to commodities. If a jurisdiction permits over-the-counter (OTC) derivatives or foreign exchange derivatives to be sold to retail customers, they would also be included in the term securities for the purposes of this section. This section does not cover commodity derivative products that are not financial in character.

${ }^{62}$ For the purposes of this section, a collective investment undertaking (CIU) refers to any entity that solicits money or other assets from the public for the purpose of investing in financial instruments. Depending on the jurisdiction, CIUs can have a variety of legal forms and names.

63 "Know Your Customer" has various meanings depending on the context. Originally developed in the securities sector, it refers to the duty of the intermediary to take affirmative steps to obtain information from the customer regarding the customer's sophistication, experience, appetite for risk and financial situation. The customer can refuse to give this information. In the event of such refusal, the intermediary can then choose not to deal with the customer or warn the customer that it does not have sufficient information to properly advise the customer as to the suitability of specific investments.

${ }^{64}$ References to national legislation and other sources are intended to be representative and not exhaustive.

${ }^{65}$ The FSA will largely transfer its consumer protection role to a new Consumer Protection and Markets Authority.

${ }^{66}$ See for example the New Jersey Department of Banking and Insurance, Division of Insurance Consumer Protection Services, http://www.nj.gov/dobi/enfcon.htm

${ }^{67}$ See Australian Financial Ombudsman Service, http://www.fos.org.au/centric/home page.jsp

${ }^{68} \mathrm{See}$ http://ec.europa.eu/consumers/cons_org/associations/index_en.htm

${ }^{69}$ The website of the sub-group can be found at http://ec.europa.eu/internal market/finservicesretail/fscg/index en.htm

${ }^{70}$ See http://www.consumersinternational.org/Templates/Internal.asp?NodeID=97533.

${ }^{71}$ See Bakker and Gross (2004).

${ }^{72}$ See http://www.insurance-canada.ca/index.php

${ }^{73}$ See for example Chapter 14 of FSA, Reforming Conduct of Business Regulation, Consultation Paper, October 2006, available at http://www.fsa.gov.uk/pubs/cp/cp06 19.pdf.

${ }^{74} \mathrm{See}$ http://www.fsa.gov.uk/smallfirms/your_firm type/credit/library/jargon.shtml

${ }^{75}$ See Rekaiti and Van den Bergh (2004).

${ }^{76} \mathrm{See}$ http://www.asic.gov.au/fido/fido.nsf/byheadline/Cooling+off+rights?openDocument)

${ }^{77}$ See http://www.moneymadeclear.fsa.gov.uk/home.html

${ }^{78}$ See http://www.fsa.gov.uk/pubs/other/icob_forms/icob4 annex1.pdf

${ }^{79}$ Run-off triangles usually arise (particularly in nonlife insurance) where it may take some time after a loss occurs before the full extent of the claims is known.

${ }^{80}$ The document can be downloaded from the FTC's website:

http://www.ftc.gov/os/2002/05/67fr36585.pdf

${ }^{81} \mathrm{http} / / / \mathrm{www} \cdot$ networkfso.org/Links.html

${ }^{82} \mathrm{http}: / /$ www.fos.org.au/centric/home_page.jsp

${ }^{83}$ Leasing is captured in the Good Practices where it is allowed to be directly provided to private persons for purposes other than professional (i.e. for consumption purposes).

${ }^{84}$ For an overview see: http://ec.europa.eu/consumers/cons_org/associations/index_en.htm

${ }^{85} \mathrm{See}$ http://ec.europa.eu/internal_market/finservices-retail/fscg/index en.htm

${ }^{86} \mathrm{See}$ http://www.consumersinternational.org/Templates/Internal.asp?NodeID=97533

${ }^{87}$ The FATF also suggests that the principles set out in the Basel Committee's Customer Due Diligence for Banks could apply to other financial institutions when relevant,

${ }^{88}$ Guarantors are excluded.

${ }^{89}$ See Bakker and Gross (2004).

${ }^{90}$ See http://www.cgap.org/gm/document-1.9.2785/Guideline disclosure.pdf

${ }^{91}$ Especially measures by United States- Credit Card Act of 2009 and Regulation Z (Truth in Lending).

${ }^{92}$ See http://www.ftc.gov/os/2002/05/67fr36585.pdf

${ }^{93}$ The International Organisation of Pensions Supervisors (IOPS) has only been in existence for a few years. The European Union has a Directive covering occupational arrangements, but not individual accounts. IOPS/OECD have also produced some broad supervisory guidelines. The US has the ERISA rules and related supervisory structures. 
${ }^{94} \mathrm{~A} 2^{\text {nd }}$ pillar scheme is typically an employer funded supplementary arrangement established under a defined contribution structure.

${ }^{95}$ Fees and charges are a particularly contentious issue as many are typically disguised and the basis of charging (e.g. on contributions or assets under management) can have an enormous impact on the sum accumulated at the retirement date.

${ }^{96}$ See http://www.whcri.org

${ }^{97}$ The project is conducted by the World Bank together with the Centro de Estudios Monetarios Latinoamericanos (CEMLA).

${ }^{98}$ International Finance Corporation, Credit Bureau Knowledge Guide, 2006.

${ }^{99}$ See http://siteresources.worldbank.org/FINANCIALSECTOR/Resources/Credit_Reporting text.pdf

${ }^{100} \mathrm{See}$ http://ec.europa.eu/internal market/finservices-retail/credit/history en.htm

${ }^{101}$ See for example Jentzsch, N., Financial Privacy - An International Comparison of Credit Reporting Systems, 2007. Jentzsch found that 80 out of 100 countries in the sample had constitutional privacy protection clauses, 35 had general data protection laws, 7 had credit reporting laws, 6 had statutory codes and 22 had industry codes of conduct.

${ }^{102}$ See also Miller (2003).

${ }^{103}$ For example, the US Fair Credit Reporting Act (1970) and the Consumer Reporting Employment Clarification Act (1998).

${ }^{104}$ See http://siteresources.worldbank.org/INTGILD/Resources/ICRPrinciples Jan2011.pdf

105 See Bellman, Johnson, and Lohse (2001).

106 See Taylor (2004).

${ }^{107}$ See "risk-based pricing notices", Section 311(a) of the Fair and Accurate Credit Transaction Act of 2003 and Notice of proposed rulemaking for correction of this Act (Fair Credit Reporting Risk-Based Pricing Regulations, 2008).

108 See Rutledge (2010).

${ }^{109}$ World Bank, Migration and Remittances Factbook 201I, November 2010

${ }^{110}$ Fardoust, Kim, and Sepúlveda (2011). See also Demirgüç-Kunt and Maksimovic (1998) on link to firm growth; Beck, Demirgüç-Kunt, and Levine (2007) on impact on income inequality; Menon (2004) on consumption smoothing and Koivu (2002) on relationship between financial system and economic growth in transition countries.

${ }^{111}$ CGAP, Advancing Financial Access for the World's Poor: Annual Report 2011, 2012

${ }^{112}$ Independent Evaluation Office of the International Monetary Fund, IMF Performance in the Run-Up to the Financial and Economic Crisis: IMF Surveillance in 2004-07, January 10, 2011.

${ }^{113}$ See California Budget Report, Locked Out 2008: The Housing Boom and Beyond, 2008. As many as half of all subprime residential mortgage borrowers in the US had high enough credit scores to qualify for standard, lower-cost bank mortgages. See also Remarks by US Federal Reserve Board Governor Edward M. Gramlich at the Financial Services Roundtable Annual Housing Policy Meeting, Chicago, Illinois May 21, 2004.

${ }^{114}$ Statement of Sheila C. Bair, Chairman of the Federal Deposit Insurance Corporation, on Modernizing Bank Supervision and Regulation before the US Senate Committee on Banking, Housing and Urban Affairs, March 19, 2009 "As the current crisis demonstrates, increasingly complex financial products combined with frequently opaque marketing and disclosure practices result in problems not just for consumers, but for institutions and investors as well."

${ }^{115}$ Remarks by Vice Chairman Martin J. Gruenberg, United States Federal Deposit Insurance Corporation at World Bank Group Global Seminar on Consumer Protection and Financial Literacy, Washington, D.C., September 2008.

116 Additional insight on the issues of mobile banking is provided by McKay and Pickens (2010).

${ }^{117}$ See Alliance for Financial Inclusion, Consumer Protection at http://www.afi-global.net/dev/policyareas-consumer-protection.htm Consumer protection and financial literacy is also listed as one of the nine principles for innovative financial inclusion. See http://www.microfinancegateway.org/gm/document1.9.44743/Innovative_Financial_Inclusion.pdf

${ }^{118}$ The term "mis-selling" generally refers to a sale of a product by a firm to a client that is not suitable for that client, whether or not a recommendation by the firm to the client is made. 
119 Joint Forum of Basel Committee on Banking Supervision, International Organization of Securities Commission and International Association of Insurance Supervisors, Customer suitability in the retail sale of financial products and services, April 2008.

${ }^{120}$ Center for the Study of Financial Innovation, Microfinance Banana Skins 2011: The CSFI survey of microfinance risk: Losing its fairy dust, February 2011

${ }^{121}$ For additional discussion of scandals, see the Case Studies in the April 2008 report of the Joint Forum of Basel Committee on Banking Supervision et al.

${ }^{122}$ See http://microfinanceafrica.net/tag/microfinance-in-andhra-pradesh/ and http://idbdocs.iadb.org/wsdocs/getdocument.aspx?docnum=35379430

${ }^{123}$ Technically speaking, asymmetric information raises two main problems: adverse selection and moral hazard. Adverse selection is also referred to as the "lemon problem". The academic literature notes that, with imperfect information on the part of lenders or prospective car buyers, borrowers with weak repayment prospects or sellers of low-quality cars ("lemons") crowd out everyone else from the market. See the seminal article by Akerlof (Akerlof (1970). This is a different issue from that of borrowers lacking sufficient information to make wise and well-informed financial decisions.

${ }^{124}$ PBS NewsHour, Graduate Students Recount Experiences with Globalization, June 1, 2007

${ }^{125}$ For example, on its website, the banking, insurance and private pension funds supervisor of Peru publishes offers by different institutions (as well as a data-base of permitted and prohibited contract terms.) See http://www.sbs.gob.pe/0/modulos/JER/JER Interna.aspx?ARE=0\&PFL=0\&JER=152 and http://www.sbs.gob.pe/0/modulos/JER/JER Interna.aspx?ARE=0\&PFL=1\&JER=980 and http://www.sbs.gob.pe/repositorioaps/0/0/jer/regu_clausulas_sbs/clausulas_prohibidas_SBS.doc. See also the worldwide remittances price data base maintained by the Payment Systems Development Group of the World Bank. Available at http://remittanceprices.worldbank.org

${ }^{126}$ See Armstrong (2008).

${ }^{127}$ Chairman Ben S. Bernanke's Speech Financial Innovation and Consumer Protection at the Federal Reserve System's Sixth Biennial Community Affairs Research Conference, Washington, D.C. April 17, 2009

${ }^{128}$ See Nier (2009).

${ }^{129}$ Rajan (2005) has pointed to the benefits in the expansion of the variety of intermediaries and financial transactions leading to improved risk-sharing, increased access to capital, and expanded diversity of opinions expressed in the marketplace. However, he also notes that any form of intermediation introduces a layer of management between the investor and the investment. The key question is whether the incentives of the managers are aligned with those of the investors. Where such incentives are misaligned, there is a higher risk of highly costly financial downturn. Nier (2009) also points to weaknesses in the originatecertify-distribute model of residential mortgage financing. He notes that for mortgage brokers and rating agencies, prudential regulation is not appropriate. Instead, what is needed is business conduct regulation.

${ }^{130}$ See Brown, Garino, Taylor and Price (2004) and Weinstein (1980).

131 See Mandell (2004). Also see ANZ Banking Group, ANZ Survey of Adult Financial Literacy in Australia, Melbourne (2003).

${ }^{132}$ See Loewenstein, O’Donoghue and Rabin (2003).

${ }^{133}$ See Rutledge (2010).

${ }^{134}$ Furthermore, strong financial literacy may help consumers to weather financial crises, as seen in recent research on Russia. See Klapper, Lusardi and Panos (2011).

${ }^{135}$ For a recent summary of current work on financial education, see Deb and Kubzansky (2012).

${ }^{136}$ For a summary of academic research on the limited effectiveness of financial education in the US, see Cole and Shastry (2007). Other analysts go further and argue that financial education fails to improve consumer decision-making and may even be harmful by developing consumer over-confidence. See Willis (2008).

${ }^{137}$ Additional insights will be gained from ongoing work on financial education, including that financed by the Russian Trust Fund for Financial Literacy and Financial Education.

138 See Nier (2009).

139 The Group of 30, formally known as "The Consultative Group on International Economic and Monetary Affairs, Inc." was founded in 1978. It is a private, nonprofit, international body composed of senior representatives of the private and public sectors and academia. See http://media.washingtonpost.com/wp- 
srv/business/documents/g30report.pdf For the Turner Review, see http://www.fsa.gov.uk/pubs/other/turner_review.pdf

${ }^{140}$ Proposed Good Practices for private pensions and credit reporting systems were also prepared, but they are presented as annexes due to the preliminary nature of the work. Further refinement will be made in the course of future revisions to the Good Practices.

${ }^{141}$ Additional ideas on application of consumer protection regulation in low-income countries may be found in Brix and McKee (2010).

${ }^{142}$ Recent research has shown that remuneration in the sale of both insurance and securities products is clearly influenced by remuneration structures. See for example, Anagol, Cole and Sarkar (2010) available at http://papers.ssrn.com/sol3/papers.cfm?abstract id=1786624

${ }^{143}$ In the US, the Federal Reserve Board has conducted extensive testing of mandatory disclosure of credit card information prior to the release of detailed regulations on disclosure. Regarding results of testing of consumer understanding of credit card disclosure in the US, see http://www.federalreserve.gov/dcca/regulationz/20070523/Execsummary.pdf http://www.ftc.gov/be/workshops/mortgage/presentations/Hogarth_Jeanne.pdf For insights into the comprehension of microfinance borrowers, see Tiwari, Khandelwal and Ramji (2008). In addition, CGAP has prepared a policy note summarizing its experience with testing financial consumer disclosure in six countries - four in Africa plus Mexico and the Philippines. See Collins, Jentzsch and Mazer (2011) available at http://www.cgap.org/gm/document-1.9.55701/FN74.pdf

${ }^{144}$ The Financial Literacy and Financial Education Trust Fund is financing a number of evaluation impact surveys, whose reports are scheduled to be completed by December 2012. See http://www.google.com/url?sa=t\&rct=i\&q=\&esrc=s\&source=web\&cd=2\&ved=0CHYQFjAB\&url=http\%3 A\%2F\%2Fsiteresources. worldbank.org\%2FSOCIALPROTECTION\%2FResources\%2F2805581235510454189\%2FRFLTF-M-

E_CfP 1Mar.docx\&ei=91yoT8vwOafE0AGZvKWrBQ\&usg=AFQjCNEAhzZMdYA_KYrDsJ3FQ62d8Y $\underline{\mathrm{ES} 8 \mathrm{w}}$ 